\title{
Helicobacter pylori Virulence Factors-Mechanisms of Bacterial Pathogenicity in the Gastric Microenvironment
}

\author{
Jacek Baj $^{1, *(\mathbb{D})}$, Alicja Forma ${ }^{2}\left(\mathbb{D}\right.$, Monika Sitarz $^{3} \mathbb{D}$, Piero Portincasa ${ }^{4}\left(\mathbb{D}\right.$, Gabriella Garruti $^{5}$, Danuta Krasowska ${ }^{6} \mathbb{D}$ \\ and Ryszard Maciejewski ${ }^{1}$
}

1 Department of Anatomy, Medical University of Lublin, 20-400 Lublin, Poland; ryszard.maciejewski@umlub.pl

2 Chair and Department of Forensic Medicine, Medical University of Lublin, 20-090 Lublin, Poland; aforma@onet.pl

3 Department of Conservative Dentistry with Endodontics, Medical University of Lublin, 20-090 Lublin, Poland; mksitarz@gmail.com

4 Clinica Medica "Augusto Murri", Department of Biomedical Sciences and Human Oncology, University of Bari "Aldo Moro", 70124 Bari, Italy; piero.portincasa@uniba.it

5 Section of Endocrinology, Department of Emergency and Organ Transplantations, University of Bari “Aldo Moro" Medical School, Piazza G. Cesare 11, 70124 Bari, Italy; gabriella.garruti@uniba.it

6 Department of Dermatology, Venerology and Paediatric Dermatology of Medical University of Lublin, 20-081 Lublin, Poland; dana.krasowska@gmail.com

* Correspondence: jacek.baj@umlub.pl; Tel.: +48-662-094-014

Citation: Baj, J.; Forma, A.; Sitarz, M.; Portincasa, P.; Garruti, G.; Krasowska, D.; Maciejewski, R. Helicobacter pylori Virulence FactorsMechanisms of Bacterial Pathogenicity in the Gastric Microenvironment. Cells 2021, 10, 27. https://dx.doi.org/10.3390/ cells10010027

Received: 11 November 2020 Accepted: 22 December 2020 Published: 25 December 2020

Publisher's Note: MDPI stays neutral with regard to jurisdictional claims in published maps and institutional affiliations.

Copyright: () 2020 by the authors. Licensee MDPI, Basel, Switzerland. This article is an open access article distributed under the terms and conditions of the Creative Commons Attribution (CC BY) license (https: / / creativecommons.org/ licenses/by/4.0/).

\begin{abstract}
Gastric cancer constitutes one of the most prevalent malignancies in both sexes; it is currently the fourth major cause of cancer-related deaths worldwide. The pathogenesis of gastric cancer is associated with the interaction between genetic and environmental factors, among which infection by Helicobacter pylori (H. pylori) is of major importance. The invasion, survival, colonization, and stimulation of further inflammation within the gastric mucosa are possible due to several evasive mechanisms induced by the virulence factors that are expressed by the bacterium. The knowledge concerning the mechanisms of $\mathrm{H}$. pylori pathogenicity is crucial to ameliorate eradication strategies preventing the possible induction of carcinogenesis. This review highlights the current state of knowledge and the most recent findings regarding $\mathrm{H}$. pylori virulence factors and their relationship with gastric premalignant lesions and further carcinogenesis.
\end{abstract}

Keywords: Helicobacter pylori; virulence factor; pathogenicity; urease; cagA; vacA; BabA; SabA; OpiA; DupA

\section{Introduction}

Helicobacter pylori (H. pylori) is a Gram-negative, helix-shaped, microaerophilic, flagellated bacterium that is capable of converting its shape from spiral to coccoid, which is believed to be involved in the enhancement of bacterial survival in the host gastric microenvironment. The spiral form of $\mathrm{H}$. pylori enables the successful motility of the bacterium, whereas the coccoid form provides the ability to colonize the mucus layer of the gastric epithelium, enhancing further invasiveness of the bacterium. Furthermore, H. pylori is capable of forming biofilms to decrease its susceptibility to several antibiotics, leading to antibiotic resistance mutations and further difficulties with bacterial eradication.

Since 1994, H. pylori has been classified as a class I carcinogen associated with the onset of gastric cancer (GC) by the World Health Organization (WHO) as well as by the International Agency for Research on Cancer [1,2]. H. pylori colonizes the gastric mucosa of nearly half of the world's population; however, in the majority of cases, the infected individuals remain asymptomatic. The prevalence of the infections induced by $\mathrm{H}$. pylori is estimated at $85-95 \%$ in developing countries and approximately 30-50\% in developed countries [3,4]. The oral-to-oral and fecal-to-oral routes are two major transmission routes of the bacterium. The adaptation mechanisms of $\mathrm{H}$. pylori include the bacterial and 
environmental factors that enable its survival in the gastric microenvironment where the acidity is at $\mathrm{pH}$ even lower than $3.0[5,6]$. The pathogenicity of $\mathrm{H}$. pylori is associated with several mechanisms, among which the alterations of the host signaling pathways, indirect inflammatory responses induced within the gastric mucosa, and direct epigenetic outcomes on gastric epithelial cells, are of major importance [7].

The acquisition of $\mathrm{H}$. pylori infection occurs most prevalently during childhood, whereas the appearance of gastrointestinal diseases is observed in adulthood [8]. Infection by $\mathrm{H}$. pylori significantly contributes to the induction of GC, which is the second most prevalent and the fourth leading cause of death worldwide, leading to more than 740,000 deaths per year [9]. Among patients with GC, H. pylori is believed to be the major causation of this malignancy in approximately $92 \%$ of patients $[10,11]$. H. pylori infection enhances the progression of the epithelial-mesenchymal transition (EMT) that induces the oncogenic alterations within the gastric mucosa, constituting one of the hallmarks of gastric carcinogenesis [12,13]. Except for GC, H. pylori is responsible for the induction and progression of other gastrointestinal impairments and diseases, including gastritis, peptic ulcer disease, dyspepsia, or mucosa-associated lymphoid tissue lymphoma (MALT); contrarily, H. pylori is a protective factor against inflammatory bowel disease (IBD) and gastroesophageal reflux disease (GERD) [14-18].

The severity of $\mathrm{H}$. pylori-related diseases is associated with numerous virulence factors; a particular genotype of the $\mathrm{H}$. pylori strain plays a crucial role. Furthermore, what is of the highest importance is an interplay between the host, gastric microenvironment, as well as bacterial virulence factors. H. pylori virulence factors are not only involved in the induction of inflammatory responses, but they also control and regulate those responses, maintaining chronic inflammation. $H$. pylori virulence factors enable the colonization and survival of the bacterium within the gastric mucosa, leading to further immune escape and ultimately, the induction of premalignant alterations. H. pylori exhibits an expanded complex of mechanisms that alters host cellular responses and signaling pathways (Table $1)$.

Table 1. Characteristics of Helicobacter pylori virulence factors that facilitate carcinogenesis and protect the bacterium from the gastric microenvironment, enabling colonization and proliferation.

Virulence Factor

Urease

Flagellum
Function

Protects from the gastric acidity

Facilitates bacterial colonization

Stimulates bacterial nutrition

Generates the proton motive force

Modulates the host immune responses (facilitated apoptosis, chemotaxis of neutrophils and monocytes, altered opsonization, enhanced release of the

pro-inflammatory cytokines)

Stimulates platelet activation Stimulates angiogenesis

Enhances bacterial motility Stimulates chemotaxis

Takes part in the biofilm formation

Facilitates inflammation and immune evasion

Stimulates inflammatory responses

Induces the release of IL-8 and IL-12

Enhances bacterial motility

Activates RUNX3, ASPP2, CDX1, and fibroblasts

Cytotoxin-associated gene A Induces EMT

Stimulates host cell growth and proliferation

Reduces the activity of PDCD4, GSK-3, microRNA-134, Afadin protein, heat shock proteins

Stimulates the induction of cancer stem cell-like properties 
Table 1. Cont.

Virulence Factor

Vacuolating cytotoxin A

\section{Function}

Involved in the formation of pores

Promotes the autophagy pathways

Forms the intracellular vacuoles and impaired autophagosomes

Induces apoptosis and necrosis

Inhibits the activity and proliferation of $\mathrm{T}$ and $\mathrm{B}$ cells

Inhibits the IFN- $\beta$ signaling inducing macrophage apoptosis Induces the release of IL-8

Differentiation of the regulatory T cells into effector T cells Prevents cellular elongation by inhibiting the Erk1/2 kinase pathways

Induces mutagenesis

Facilitates inflammation

Catalase

Protects H. pylori from complement-mediated killing

Maintains bacterial survival at the cell surface of the phagocytes and in the macrophage phagosomes

Protects H. pylori from phagocytosis

Facilitates bacterial colonization Protects from ROS

Superoxidase dismutase

Inhibits the production of pro-inflammatory cytokines Stimulates the activation of the macrophages

Lewis antigens

Protects H. pylori from the host defense mechanisms Enhances bacterial survival

Enhances the adhesive properties and further internalization

Stimulates apoptosis
Prevents bacterial killing

Provides acid resistance in the gastric microenvironment

Arginase

Inhibits the proliferation of $\mathrm{T}$ cells

Inhibits the production of $\mathrm{NO}$

Impairs the host immune responses

Induces the apoptosis of macrophages

Impairs Th1/Th17 differentiation

Degradation of various lipids

Damage the mucus layer

Phospholipases

Stimulate chronic inflammation

Facilitate bacterial colonization and survival

Activate the ERK1/2 signaling pathway

Induces the host inflammatory responses by molecular mimicry

Protects the bacterium from potentially toxic compounds

Activates the TLR4, TLR2, PD-1, MMP-9, PLC/PKC/PI3K, JAK/STAT pathway,

TNF- $\alpha$, IFN- $\gamma$, IL-10, IL-12, IL-18, EPA-78, MCP-1, IL-8, IL-1 $\beta$, and -4, -6, -7,

Lipopolysaccharide

-9 claudins

Facilitates Th1 immune responses

Activates neutrophils promoting oxidative stress reactions

Induces monocyte inflammatory responses and monocyte

transendothelial migration

Disrupts the mucus secretion

Enables bacterial adherence to gastric epithelial cells

Blood group antigen-binding adhesin

Stimulates the delivery of toxins (due to the increased T4SS activity)

Stimulates the inflammatory responses (excessive IL-8 release, 
Table 1. Cont.

Virulence Factor

Sialic acid-binding adhesin

Duodenal ulcer promoting gene A

LacdiNAc-specific adhesin

Helicobacter pylori outer membrane protein $\mathrm{Q}$

Neutrophil-activating protein

Helicobacter pylori outer membrane protein $Z$ $\gamma$-glutamyl-transpeptidase

\section{Function}

Stimulates neutrophil activation and infiltration

Facilitates bacterial colonization Induces the oxidative damage

Activates the apoptotic cascade

Promotes the secretion of the pro-inflammatory cytokines such as IL-1, IL-6, IL-8,

IL-11 IL-17, matrix metalloproteinase 1 (MMP-1), TNF- $\alpha$, RANTES

Regulates $\beta$-catenin levels

Inhibits the maturation of the dendritic cells

Takes part in CagA delivery into the host cells Increases microRNA-30b levels

Involved in the formation of T4SS

Stimulates the infiltration of the inflammatory cells

Facilitates urease and IL- 8 secretion and IL-12 release from the monocytes

Activates the mitochondria-mediated apoptotic pathways

Facilitates bacterial tolerance in the acidic microenvironment

Enables bacterial adherence to gastric epithelial cells Stimulates bacterial colonization

Takes part in the formation of the biofilm

Induces the release of pro-inflammatory factors (IL-6 and IL-8)

Facilitates adherence to gastric epithelial cells

Facilitates adherence to gastric epithelial cells

Enables bacterial survival in the acidic gastric microenvironment

Stimulates the infiltration of pro-inflammatory factors

Facilitates T4SS activity

Enables the survival of neutrophils

Inhibits natural killer and $\mathrm{T}$ cells functions

Facilitates the adherence to gastric epithelial cells Disturbs gastric acid secretion

Induces oxidative DNA damage

Stimulates the release of pro-inflammatory factors (IL-8, IL-1)

Facilitates granulocytic and lymphocytic infiltrations

Prevents H. pylori from the phagocytosis and immune responses Regulates the responses from the CD $4^{+}$T-cells, IL- 4 , and IFN- $\gamma$ pathways

Stimulates the secretion of IL-8

Crucial for proper bacterial growth, survival, and antibiotic resistance Interrupts the autophagosome-lysosome fusion

Induces the release of ROS

Inhibits cellular proliferation

Facilitates apoptosis and necrosis

Incudes the release of IL-8, IL-10, COX-2, inducible iNOS, caspase-3 and -9

Inhibits CD4+ T cell proliferation and stimulates CD8+ T cells infiltration

Prevents the differentiation of the dendritic cells

Stimulates DNA damage

Reduces cell viability

Facilitates neutrophil adherence to gastric epithelial cells

Produces ROS and myeloperoxidase

Activates neutrophils and mast cells and the migration of the monocytes Stimulates the infiltration of monocytes and polymorphonuclear granulocytes Stimulates the release of IL- 8, MIP- $1 \alpha$, MIP- $1 \beta$, TNF- $\alpha$, IL- 6 , $\beta$-hexosaminidase

Impairs the epithelial tight junctions and basal membranes

Facilitates H. pylori growth 
Table 1. Cont.

Virulence Factor

High temperature requirement $\mathrm{A}$
Function

Impairs the functions of the epithelial barrier by disrupting adherens junctions, tight junctions, and extracellular matrix proteins

Facilitates $H$. pylori migration properties

Promotes CagA injection into the host cells

Prevents H. pylori from stress conditions

Maintains the proper structural and functional properties of the cellular proteins Protects from the oxidative stress

Regulates apoptosis and autophagy Crucial for proper urease activation

Heat shock proteins

Induces the release of COX-2, IL-8, TNF- $\alpha$, MMP3, and MMP7

Facilitates adherence to gastric epithelial cells

Facilitates tumor cell migrations

Enhances angiogenesis

\section{Urease}

Urease is one of the most essential H. pylori virulence factors involved in bacterial metabolism and colonization within the gastric mucosa; it is the most abundantly expressed protein by this bacterium. H. pylori urease can be found in both-the bacterial cytoplasmic compartment and on the surface of the bacteria; thus, two types of urease can be distinguished based on its localization-internal and external [19]. External urease is primarily produced during the cell lysis and works most sufficiently at $\mathrm{pH}$ between 5.0 and 8.5 , whereas the internal urease shows its activity at $\mathrm{pH}$ between 2.5 and 6.5. The enzymatic reaction of urease is based on the hydrolysis of urea into ammonia and carbamate, which is further decomposed into another molecule of ammonia and carbonic acid that eventually induces the increase in gastric $\mathrm{pH}$; the whole process is nickel-dependent. Paradoxically, $\mathrm{H}$. pylori colonization might be terminated when the mucus $\mathrm{pH}$ will rise above $8 \mathrm{pH}$; this mechanism is probably induced in order to prevent the excessively high amounts of bacteria in the gastric mucus [20]. Except for urease, H. pylori induces the production of other ammonia-producing enzymes such as aliphatic amidases $\mathrm{E}$ and $\mathrm{F}$ (AmiE and AmiF) [21].

Urease is a critical factor that facilitates bacterial colonization within the gastric mucosa; urease-negative mutants fail in colonizing the gastric mucosa at physiological $\mathrm{pH}$ levels as sufficiently as urease-positive H. pylori strains [22]. Except for facilitated colonization of $\mathrm{H}$. pylori, urease protects the bacterium from gastric acidity due to the increased release of ammonia, promotes bacterial nutrition via the release of the host metabolites, and also generates the proton motive force during the hydrolysis of urea [22]. Furthermore, urease modulates host immune responses via several mechanisms, including altered opsonization, enhanced chemotaxis of neutrophils and monocytes, facilitated apoptosis due to binding to the class II major histocompatibility complex (MHC) receptors, or enhanced release of the pro-inflammatory cytokines [23]. Urease also takes part in platelet activation via the lipoxygenase-derived eicosanoids [24]. Urease is believed to stimulate angiogenesis, leading to the enhanced progression of GC [25]. In H. pylori species, urease activity is controlled by both the environmental $\mathrm{pH}$ and the availability of the cofactor nickel; bacterial cultures that are supplemented with nickel tend to exhibit significantly increased urease activity [26]. H. pylori in the spiral form presents higher urease activity compared with the bacterium present in the coccoid form [21]. Moreover, urease and catalase activity, as well as protein synthesis by $\mathrm{H}$. pylori, might be impaired at very low $\mathrm{pH}$ [27]. Greater urease activity might be associated with a higher risk of induction of the histopathological alterations within the gastric mucosa and further gastric carcinogenesis [28]. Urease activity might be modulated by the $f l b A$ gene, the same gene that is involved in flagellar biosynthesis [29]. The inhibition of urease is considered to constitute a potential therapeutic strategy preventing H. pylori-related diseases [30]. 


\section{Flagellum}

The H. pylori flagellum constitutes a crucial factor enabling bacterial motility and chemotaxis properties. Physiologically, H. pylori possesses a bundle of 2-6 sheathed unipolar flagella; each of the flagella is approximately $3 \mu \mathrm{m}$ long and the surrounding sheaths enable protection from the gastric acidic microenvironment [31,32]. The speed of $\mathrm{H}$. pylori movement is associated with the exact number of flagella and might differ among species [33]. Two flagellin proteins—FlaA and FlaB-constitute major components of the flagellar filament. It was observed that FlaA-negative $\mathrm{H}$. pylori mutants do not produce flagella at all, whereas FlaB-negative mutants might produce flagella; however, they are not fully functional [34]. Kao et al. (2014) demonstrated that $\operatorname{csr} A \mathrm{H}$. pylori mutants showed decreased motility and adherence properties compared to the wild-type H. pylori presenting the relevance of $c s r A$ in the flagellar formation [35]. The motility of the flagella is provided by the proton motive force, which might explain bacterial chemotactic movements towards urea as urease-driven hydrolysis provides the generation of the proton motive force specifically [36,37].

Flagellum, as a factor that provides bacterial motility, enables further colonization in the gastric mucosa; therefore, it constitutes one of the most crucial virulence factors associated with $\mathrm{H}$. pylori pathogenicity specifically at the very first stages of bacterial invasion. It was demonstrated that less motile strains of $\mathrm{H}$. pylori present difficulties with further colonization within the gastric mucosa; furthermore, bacterial motility correlates with bacterial infectivity as well [38]. It was observed that non-flagellated H. pylori mutants are not capable of colonizing the gastric mucosa, providing an insight that bacterial motility is fundamental for further bacterial pathogenicity [39]. Flagellar motility is controlled by the so-called chemotaxis pathway that controls bacterial motility and its relationships with the microenvironment $[40,41]$. Except for colonization, flagella are believed to be involved in H. pylori-induced inflammation and immune invasion; furthermore, flagella take part in biofilm formation [42,43]. Several flagellins that compose bacterial flagella such as HpA, FlaA, or FlaB might promote humoral immunity and stimulate specific antibody responses after infection $[44,45]$. It was observed that $\mathrm{H}$. pylori strains that possess highly motile properties induce an increased release of IL-8 $[46,47]$. It was suggested that genes that regulate flagellar synthesis might also be involved in the regulation of other virulence factors such as adhesins [48].

\section{Cytotoxin-Associated Gene A}

H. pylori strains can be generally categorized into two subtypes-cytotoxin-associated gene A (CagA)-positive and CagA-negative $\mathrm{H}$. pylori strains. CagA along with a type 4 secretion system (T4SS) are encoded by the cag pathogenicity island (cagPAI) that plays a key role in carcinogenesis. CagA is injected into the cell via the pilus formed by T4SS and induces cellular alterations that impair cell motility, cellular proliferation, and apoptosis, as well as alters the arrangement of the whole cytoskeleton. The adherence of $\mathrm{H}$. pylori to the gastric epithelial cells induces the expression of cagA and the process seems to be controlled by the Fur protein among others [49]. The presence of CagA is usually associated with a higher prevalence of inflammatory responses and greater damage induced within the gastric mucosa; however, the CagA status alone is not the only decisive factor regarding further gastrointestinal impairments induced by $\mathrm{H}$. pylori.

Generally, infections by CagA-positive $\mathrm{H}$. pylori strains are associated with greater severity and worse clinical outcome of patients. Kyrillos et al. (2015) showed that cagA expression might be associated with the bacteriophage genes (phage orthologous genes) affecting $\mathrm{H}$. pylori virulence [50]. CagA-positive $\mathrm{H}$. pylori strains stimulate the elevation of IL-8 and IL-12 levels in the sera of infected individuals [51,52]. The amounts of interleukins that are secreted during $\mathrm{H}$. pylori infection are highly associated with the number and the variations within C-terminal Glu-Pro-Ile-Tyr-Ala (EPIYA) motifs; for instance, $\mathrm{H}$. pylori strains with the EPIYA-D motif are prone to release higher amounts of IL-8 compared to other variations [53]. An animal model also showed that CagA-positive strains with 
variations in the EPIYA C motifs might affect the number of gastrin-producing $\mathrm{G}$ cells and somatostatin-producing D cells [54]. Lai et al. (2008) observed that cholesterol might inhibit excessive CagA-related IL-8 release as well as the "hummingbird" phenotype [55].

CagA-positive strains are more motile compared to the CagA-negative strains, which indicates that CagA is also associated with bacterial motility [56]. Furthermore, an upregulation of CagA in gastric cells requires the flagellar regulatory system of $\mathrm{H}$. pylori, indicating the cooperation between $\mathrm{H}$. pylori motility and CagA presence [57]. CagA promotes carcinogenesis via numerous pathways affecting the activity of tumor suppressor proteins such as run-related transcription factor 3 (RUNX3) or apoptosis-stimulating protein of p53 2 (ASPP2) [58]. P53 mutations are more prevalent in tumors induced by CagA-positive strains than the negative ones [59]. $\mathrm{Cag} A$ gene presents several variants and there is a correlation between the particular cagA genotype and patients' ethnicity [60-67]. CagA presents antiapoptotic effects, stimulates motility, and induces host cell growth with proliferation. Choi et al. (2019) showed that enhanced gastric carcinogenesis might be associated with the overexpression of the transcription factor CDX1, which is stimulated by the CagApositive strains [68]. Moreover, CagA is highly associated with the induction and further progression of the EMT within the gastric mucosa, which is associated with greater invasiveness properties. The process is stimulated via several CagA-related mechanisms such as the downregulation of programmed cell death protein 4 (PDCD4), induction of cancer stem cell-like properties, reduction in glycogen synthase kinase 3 (GSK-3) activity, overactivation of fibroblasts, suppression of microRNA-134, altering the yes-associated protein (YAP) pathway, or Afadin protein downregulation [69-76]. Particular cagA genotypes present different severity of enhanced IL- 8 and cytotoxin production, inflammatory responses, or apoptosis in gastric epithelial cells. CagA represses host heat shock proteins' expression by downregulating the levels of host HSPH1 (HSP105), HSPA1A (HSP72), and HSPD1 (HSP60) [77].

Infection by the CagA-positive strains promotes the induction of gastritis (active or atrophic), duodenal ulcers, and gastric carcinogenesis; [57,78,79]. The co-expression of CagA, outer inflammatory protein A (OipA), vacuolating cytotoxin (VacA), and blood group antigen-binding adhesin (BabA) significantly enhances the inflammatory responses, ultimately worsening the clinical outcome of patients and increasing the probability of greater gastrointestinal diseases incidence [80]. Even though CagA-positive strains seem to be much more pathogenic than the CagA-negative strains, CagA-positive strains are easier to eradicate, according to the meta-analysis by Wang et al. (2017) [81].

\section{Vacuolating Cytotoxin A}

Vacuolating cytotoxin A (VacA) is a cytotoxin involved in the formation of pores where mechanisms of action and final pathogenicity slightly differ depending on the time of exposure to the host cells. In cases of acute exposure, VacA promotes the autophagy pathways in cells, whereas, during chronic exposure, VacA promotes the appearance of impaired autophagosomes as well as induces the formation of intracellular vacuoles that enable the survival of $\mathrm{H}$. pylori in the host cells [82]. VacA constitutes one of the most crucial virulence factors that enable bacterial colonization and survival in the gastric epithelium; the vacA gene is present in all of the H. pylori strains. Receptor-like protein tyrosine phosphatases $\alpha$ and $\beta$ (RPTP-RPTP $\alpha$ and RPTP $\beta$ ), low-density lipoprotein receptor-related protein-1 (LRP-1), or sphingomyelin are major types of receptors to which VacA binds [83,84]. So far, several vacA genotypes are distinguished including s1, s2, m1, $\mathrm{m} 2, \mathrm{~s} 1 \mathrm{~m} 1, \mathrm{~s} 1 \mathrm{~m} 2, \mathrm{~s} 2 \mathrm{~m} 2$, and $\mathrm{s} 2 \mathrm{~m} 1$. The VacA s1 genotype is one of the most abundant in H. pylori-infected patients and there is an association between this genotype and peptic ulcer disease [85]. VacA s1m1 is commonly found in H. pylori-infected patients with chronic gastritis, whereas in $\mathrm{H}$. pylori-induced gastric cancer, usually s1 and $\mathrm{m} 1$ VacA genotypes are most prevalent $[86,87]$. It was suggested that VacA polymorphism might be associated with the clinical phenotype of the $\mathrm{H}$. pylori infection. 
Except for autophagy and disruption of the endosomal and lysosomal functions, VacA is involved in many other processes that impair gastric epithelial cells such as alterations in mitochondrial functioning, as well as apoptosis and necrosis [88]. Furthermore, VacA significantly affects the immune cells by inhibiting the activation and proliferation of $\mathrm{T}$ cells and B cells and inducing apoptosis in macrophages primarily by inhibition of the IFN- $\beta$ signaling; VacA is also involved in the induction of an excessive release of IL-8 $[89,90]$. Furthermore, VacA stimulates the differentiation of the regulatory T cells into effector T cells, which also contributes to the persistence of $\mathrm{H}$. pylori infection [91]. Gastric epithelial cells are targeted by the VacA-containing endosomes that afterward activate several cellular degradative systems inducing host immune-inflammatory responses and further damage of the organelles [92].

Abdullah et al. (2019) demonstrated a synergy between VacA and CagA, showing that CagA might accumulate within the VacA-induced impaired autophagosomes [93]. This synergy is also observed in cases of the acquisition of specific nutrients (such as iron) by the bacterium, wherein VacA and CagA interplay with one another. VacA inhibits the Erk1/2 kinase pathways preventing cellular elongation induced by CagA [94]. Moreover, there is evidence of synergy between VacA, CagA, and BabA; an interplay between those factors significantly worsens the inflammatory responses and is associated with a higher incidence of intestinal metaplasia [80]. It was demonstrated that weak bases such as ammonia released in excessive amounts during $\mathrm{H}$. pylori infection might significantly stimulate cell death via the enhancement of VacA activity [95]. Similar to CagA, VacA is also associated with phage orthologous genes, enhancing H. pylori pathogenicity [50].

Various vacA genotypes are further associated with different morbidity incidents of such gastrointestinal disorders as GC or peptic ulcer disease, as well as the clinical outcome of patients [66,78,96-102]. VacA-positive strains are associated with a greater prevalence of gastric premalignant lesions, as well as GC [103]. Different vacA genotypes might also be associated with the severity of H. pylori-induced inflammation [104]. Furthermore, particular vacA genotypes might induce the enhanced expression of the transforming growth factor-beta 1 (TGF- $\beta 1$ ) mRNA levels [105]. Similar to cag $A$, vac $A$ expression might be stimulated in a Fur-dependent manner [49]. Figura et al. (2015) demonstrated that vacA polymorphism might correlate with the histological type of GC; this characteristic is not applicable in the case of $\operatorname{cag} A$ [106]. It was proven that vacA s1 strains are far easier to eradicate compared to vacA s2 strains [81]. However, VacA is involved in the formation of intracellular reservoirs enabling $\mathrm{H}$. pylori survival in the gastric environment even after eradication therapy [107].

\section{Catalase}

Catalase is an enzyme that converts hydrogen peroxide $\left(\mathrm{H}_{2} \mathrm{O}_{2}\right)$ into water $\left(\mathrm{H}_{2} \mathrm{O}\right)$ and molecular oxygen $\left(\mathrm{O}_{2}\right)$ and is one of the most abundant proteins in both-plant and animal cells. Three unrelated types of catalase can be distinguished and those include the "classical" catalase, catalase-peroxidase, and manganese-containing catalase. Catalase is implicated in numerous pathological processes such as inflammation, apoptosis prevention, as well as induction of mutagenesis resulting in a vast number of tumors. Catalase presents its activity in the cytoplasm and periplasm; it can also be surface-expressed [108].

Catalase levels are estimated at $4-5 \%$ of $\mathrm{H}$. pylori total protein content and it is one of the most highly expressed proteins in $\mathrm{H}$. pylori strains obtained from the gastric mucosa $[109,110]$. H. pylori catalase is more resistant to inhibition by cyanide or aminotriazole, compared to catalase from other species [111]. It was demonstrated that catalase is involved in bacterial protection from oxidants and oxidative stress, suggesting its heterogeneous ways of action during infection [112]. Furthermore, Richter et al. (2016) showed that catalase might be involved in the protection of $\mathrm{H}$. pylori from complement-mediated killing and this process is strongly associated with the vitronectin $(\mathrm{Vn})$ that regulates the complement system [113]. The authors also showed that catalase, as a Vn-binding protein, might enhance the evasion of an infected individual's immunity. Catalase activity is also crucial in 
the maintenance of bacterial survival at the cell surface of the phagocytes [114]. Catalase also enhances $\mathrm{H}$. pylori survival within the macrophage phagosomes [115]. An animal model showed that mice lacking catalase showed significantly decreased ability to colonize in the gastric mucosa, suggesting a role of catalase in H. pylori colonization [116]. H. pylori catalase prevents the bacterium from toxic long-chain fatty acids and their metabolites as well as provides $\mathrm{H}$. pylori protection from phagocytosis; catalase is also involved in the modulation of immune responses [117-119]. H. pylori catalase activity is controlled by Fur protein and iron concentrations; it was demonstrated that strains of $\mathrm{H}$. pylori that were Fur-deficient and grown on a medium with low iron concentrations showed significantly reduced catalase activity [120]. It was demonstrated that a vaccination that contains pcDNA3.1 encoding $\mathrm{H}$. pylori catalase suppresses further bacterial colonization and inflammatory responses induced in gastric mucosa; furthermore, humoral immune responses are induced by such a vaccination [121].

\section{Superoxidase Dismutase}

Superoxide dismutase (SOD) is one of the H. pylori enzymes that prevents the bacterium from reactive oxygen species (ROS), enabling the maintenance of the proper homeostasis. Contrarily to catalase, SOD is located on the cell surface only. SOD facilitates the dismutation of superoxide to oxygen, preventing excessive amounts of toxic superoxide free radicals. SOD, which is a metalloenzyme, can be categorized into three isoforms depending on its properties and chemical composition-copper-zinc SOD $(\mathrm{Cu} / \mathrm{Zn}-\mathrm{SOD})$, manganese SOD (Mn-SOD), and extracellular matrix SOD (EC-SOD). H. pylori SOD requires iron $(\mathrm{Fe})$ for proper and effective functioning, acting as a SOD cofactor. Any alterations in the cellular Fe concentrations decrease SOD activity, enhancing cellular susceptibility to oxidative damage.

H. pylori-infected individuals with moderate to severe gastric mucosa inflammation present greater expression of Mn-SOD than individuals with the intact gastric mucosa. Mn-SOD expression was observed to be more enhanced primarily within the pit cells of the antrum and not the corpus [122]. It was reported that exposure to the CagA-positive $\mathrm{H}$. pylori strains results in significantly greater SOD, catalase, and glutathione peroxidase activities compared to exposure to the CagA-negative strains [123]. SOD is involved in the inhibition of the $\mathrm{HOCl}$ and $\mathrm{NO}$ /peroxynitrite signaling pathways, enhancing the survival of the already transformed cells from apoptosis [124]. Negovan et al. (2018) demonstrated that MnSOD Ala16Val polymorphism might be associated with a higher risk of reactive gastropathy [125]. H. pylori SOD inhibits the production of the proinflammatory cytokines (by downregulating the nuclear factor kappa B (NF- $\mathrm{kB}$ ) activation pathways), as well as macrophage inflammatory protein 2 (MIP-2) (IL-8 homolog) via activation of the macrophages [126]. Noguchi et al. (2002) demonstrated that only MnSOD and not $\mathrm{Cu} / \mathrm{Zn}-\mathrm{SOD}$ provides effective protection against ROS [127]. SOD-deficient $\mathrm{H}$. pylori mutants present a greater susceptibility to oxidative damage as well as fail in colonizing the gastric mucosa, presenting the relevance of SOD in the proper bacterial colonization process. Except for colonization, SOD expression is crucial for bacterial growth and survival primarily in the host microenvironment with a high intensity of oxidative stress [128]. Furthermore, there is a relationship between SOD activity and the onset and progress of gastric diseases [129].

\section{Lewis Antigens}

Lewis (Le) antigens are fucosylated glycolipids that constitute one of the components of the H. pylori O-specific chain of the lipopolysaccharide (LPS) and the majority of H. pylori strains express at least one type of Le antigen. Le antigens are expressed on the gastric epithelial cells; thus, $\mathrm{H}$. pylori molecular mimicry in the form of Le antigens expression on the bacterial cell surface provides one of the most effective mechanisms enabling H. pylori colonization within the gastric mucosa, evoking the host immune responses. The expression of Le antigens on the bacterial cell surface prevents the bacterium 
from the host defense mechanisms promoting bacterial survival. Le antigens expression within the gastric epithelial cells might differ depending on the clinicopathological features of the infected patients and different Le types might be expressed depending on whether a patient will develop chronic gastritis or GC specifically [130]. Except for colonization, Le antigens are also crucial for the bacterial adherence to the cells and further internalization that induces chronic and persistent $\mathrm{H}$. pylori infection [131,132].

Gastric epithelial cells and LPS might express various Le antigens at the same time, among which two major Le antigen types can be distinguished-type $1\left(\mathrm{Le}^{\mathrm{a}}\right.$ and $\left.\mathrm{Le}^{\mathrm{b}}\right)$ and type $2\left(\mathrm{Le}^{\mathrm{x}}\right.$ and $\left.\mathrm{Le}^{\mathrm{y}}\right)$. It is estimated that approximately $80-90 \%$ of $\mathrm{H}$. pylori strains express $\mathrm{Le}^{\mathrm{x}}$ or Le $\mathrm{L}^{\mathrm{y}}$ [133]. Le antigens' expression patterns might differ depending on the particular area in gastric mucosa as well as the intensification of inflammation or metaplastic alterations. Moreover, Le antigens' expression is associated with the particular geographic origin of the H. pylori strain [134]. Le ${ }^{\mathrm{b}}$ expressed on the gastric epithelial cells constitutes the major site of the $\mathrm{H}$. pylori attachment; however, there are incidents of bacterial colonization that are independent of particular Le antigen expression [135,136]. H. pylori Le antigens expression depends on the time of the bacterial growth being mostly expressed in a growth phase-dependent manner. Different patterns of Le antigens' expression were observed in adults and children-for instance, Le ${ }^{\mathrm{b}}$ expression correlates with the bacterial distribution within the antrum and corpus of the adult patients, whereas in children, it might increase the risk of ulceration $[137,138]$. Furthermore, there are differences in the Le antigens' expression regarding symptomatic and asymptomatic $\mathrm{H}$. pylori-infected individuals; asymptomatic individuals tend to present significantly lowered expression of Le $^{x}$ antigen and the complete absence of type 1 Lewis antigens, compared to the infected symptomatic individuals [139].

Martin et al. (2006) demonstrated a relationship between the ABO group and Le antigens expression, indicating that individuals with $0 \mathrm{Le}(\mathrm{a}-\mathrm{b}+)$ and $\mathrm{A}_{2} \mathrm{Le}(\mathrm{a}-\mathrm{b}+)$ phenotypes might be more susceptible to $\mathrm{H}$. pylori infection [140]. Anti-Le antibodies are present in the sera of patients infected by H. pylori as well as those with an H. pylori-induced GC and according to some research, this response is strictly associated with the bacterial Le phenotype [141]. Furthermore, the presence of the $\mathrm{Le}^{\mathrm{x}} \operatorname{IgM}$ antibodies in the gastric lumen enhances the adhesive properties of $\mathrm{H}$. pylori strains, primarily those which express high amounts of the $\mathrm{Le}^{\mathrm{x}}$ antigen [142]. However, it was demonstrated that outer membrane vesicles (OMVs), produced during H. pylori invasion, have the ability to absorb anti-Le antibodies from the sera of infected individuals, enabling further $\mathrm{H}$. pylori growth and colonization [143,144].

\section{Arginase}

Arginases are $\mathrm{Mn}^{2+}$-metalloenzymes belonging to the ureohydrolase family that catalyze the hydrolysis of L-arginine into L-ornithine and urea during the urea cycle [145]. There are two distinct isoforms of arginase-type I and II-that have been identified in eukaryotes. Arginase I is mainly expressed in the liver and is involved in the last step of the urea cycle, whereas arginase II is a mitochondrial enzyme responsible for L-arginine homeostasis. Arginases are the antagonists of the inducible nitric oxide synthase (iNOS); they also stimulate apoptosis and prevent bacterial killing.

H. pylori arginase is encoded by the RocF gene; arginase is crucial for bacterial colonization since it provides acid resistance in the gastric microenvironment. H. pylori arginase shows a similarity to arginase II, however, with the presence of additional acidic residues near the $\mathrm{N}$-terminus. Contrarily to other arginases, $\mathrm{H}$. pylori arginase exhibits higher catalytic activity with $\mathrm{Co}^{2+}$ or $\mathrm{Ni}^{2+}$ rather than $\mathrm{Mn}^{2+}$ as a cofactor and shows greater activity at the acidic $\mathrm{pH}$ instead of the alkaline; the optimal activity of arginase is shown at $\mathrm{pH} 6.1[146,147]$. The animal studies have shown that arginase-deficient H. pylori are more prone to be killed by the macrophages in a NO-dependent manner; arginase also inhibits the proliferation of the T cells mainly by the reduction in CD3 , expression [148]. Furthermore, arginase inhibits the production of $\mathrm{NO}$ which eventually impairs the bactericidal 
activity of the macrophages [149]. The major mechanism of arginase-associated impairments of the host immune responses is due to the downregulation of NO production [150]. It was demonstrated that during the acute stages of $\mathrm{H}$. pylori infection, the inhibition of arginase increased NO and iNOS production in the macrophages [151]. H. pylori arginase expression alters the immune responses by affecting M1 macrophage activation, diminishing Th1/Th17 T-cell differentiation, as well as controlling the IL-8 transcription in gastric epithelial cells [152,153]. Moreover, the upregulated expression of arginase II in H. pyloriinfected tissues induces the apoptosis of the macrophages [154]. Arginase is essential for H. pylori survival in the acidic microenvironment; however, it is not crucial for bacterial colonization.

\section{Phospholipases}

Outer membrane phospholipase A (OMPLA) of H. pylori is involved in the degradation of various lipids, enabling effective bacterial permeability, especially during stress conditions. Furthermore, H. pylori synthesizes phospholipase A2 (PLA 2$)$, phospholipase A1 ( PLA $_{1}$ ), as well as phospholipase C (PLC) and phospholipase D (PLD) that degrade phosphatidylcholine and phosphatidylethanolamine [155]. Due to the damages of the mucus layer induced by the H. pylori phospholipases, gastric epithelial cells become progressively impaired and lose their physiological functions. Except for mucosal damage, phospholipases promote the chronic inflammation that might further induce the formation of peptic ulcers. This enables further bacterial colonization and survival within the gastric microenvironment. It was demonstrated that $\mathrm{H}$. pylori strains that secrete greater amounts of phospholipases significantly increase the risk of chronic gastritis and subsequent carcinogenesis [156]. The secretion of phospholipases is also associated with the induction of several inflammatory responses by the stimulation of arachidonic acid (a precursor of prostaglandins and leukotrienes) and lysophospholipids production. Sitaraman et al. (2012) showed that $\mathrm{H}$. pylori PLD activates the ERK1/2 signaling pathway in gastric epithelial cells, inducing further cellular impairments [157].

\section{Lipopolysaccharide}

Lipopolysaccharide (LPS) is the component of the H. pylori outer membrane that constitutes one of the most essential virulence factors, enabling the induction and progression of a chronic bacterial infection. LPS is composed of three major parts, including the core oligosaccharide, the lipid-A region, and the O-antigen; cholesterol is considered to play a crucial role in the maintenance of the LPS structure $[158,159]$. It was demonstrated that $\mathrm{O}$-antigen can directly induce the host inflammatory responses due to molecular mimicry [160-164]. Iron availability is crucial for LPS expression by H. pylori; it was observed that iron-deficient strains expressed significantly lower amounts of LPS [165]. One of the intermediate metabolites of LPS, heptose-1,7-bisphosphate (HBP), plays a role in the induction of the pro-inflammatory responses as well as IL-8 release in human gastric epithelial cells [166]. Furthermore, a release of HBP by LPS translocation via T4SS facilitates NFKB-dependent inflammation [167,168].

LPS was reported to differ among particular $\mathrm{H}$. pylori strains primarily by glucanheptane linker presence or absence, depending on the geographical occurrence of the H. pylori strains [169]. Being embedded in the bacterial outer membrane, LPS constitutes a barrier protecting $\mathrm{H}$. pylori from the compounds that could be potentially toxic for the bacterium. Yokota et al. (2012) proposed the division of LPS into two antigenic phenotypesweakly antigenic epitope-carrying LPS and highly antigenic epitope-carrying LPS that is most prevalently expressed in GC patients with chronic and severe inflammation [170].

H. pylori LPS is recognized by toll-like receptor 4 (TLR4)/MD-2 where toxic activity is slightly slower and weaker compared to other Gram-negative bacteria species. Some research demonstrated that several H. pylori strains might act as TLR4 antagonists [171]. Apart from TLR4, LPS activates TLR-2 expressed in the cellular membrane, inducing the NFKB-dependent expression of the $-4,-6,-7$, and -9 claudins as well as enhanced Th1 
immune responses [172,173]. The expression of the above-mentioned claudins in GC patients is associated with poorer clinical outcome and shorter survival. It was demonstrated that gastric carcinogenesis might be promoted via LPS-TLR4 pathways during H. pylori infection [174]. LPS type 1 (but not type 2) has an ability to activate TAK1 and TAB1, inducing the enhanced expression of mitogen oxidase 1 (Mox1) and p67-phox also via the stimulation of TLR4 in gastric pit cells [175]. Moreover, NFKB activation via LPS stimulates overexpression of the programmed death-ligand 1 (PD-1) that significantly contributes to the progression of gastric carcinogenesis [176].

LPS enables chronic $H$. pylori persistence that significantly contributes to the induction of the host inflammatory responses, resulting in chronic inflammation, peptic ulcers, gastritis, and further gastric carcinogenesis. Furthermore, LPS presents a capacity to activate neutrophils, enhancing the onset of the oxidative stress reactions [177]. Gastric inflammation and cellular proliferation might be stimulated by the MEK1/2-ERK1/2 mitogen-activated protein kinase cascade that is regulated by LPS [178]. LPS can form an LPS-TLR4-myeloid differential protein-2 (MD-2) multimer that promotes further enhanced cytokine release and enhanced activation of the pro-inflammatory signaling pathways. Furthermore, the TLR4-MD-2 pathway significantly affects GC proliferation and migration and the whole process is induced by the LPS-mediated overexpression of CXC chemokine receptor 7 (CXCR7) [179]. Inflammatory responses within the gastric microenvironment can also be enhanced by the LPS-related protein kinase C $\delta$ (PKC $\delta$ )-mediated phosphorylation of spleen tyrosine kinase (Syk), pathways activated after LPS binding to TLR4, MMP-9 secretion, as well as PLC/PKC/PI3K activation [180,181]. LPS is involved in the induction of monocyte inflammatory responses as well as monocyte transendothelial migration; it was demonstrated that LPS might be a major activating factor of several monocyte functions [182]. LPS mediates IL- 8 and IL-1 $\beta$ release from the macrophages, whereas $I L-1 \beta$ gene polymorphism is associated with the risk and severity of H. pyloriinduced GC $[183,184]$. Furthermore, LPS mediates the release of excessive amounts of other interleukins and immune mediators such as TNF- $\alpha$, IFN- $\gamma$, IL-10, IL-12, IL-18, epithelial neutrophil-activating peptide 78 (EPA-78), and monocyte chemotactic protein 1 (MCP1) [185-187]. Pan et al. (2013) demonstrated that there is a relationship between T309G polymorphism in the MDM2 gene, $\mathrm{H}$. pylori infection, and further gastric carcinogenesis, and the whole process might be intensified by LPS [188]. LPS regulates the expression of Pellino (1 and 2) proteins that stimulate further pro-inflammatory chemokine release, triggering inflammation [189]. LPS dysregulates the secretion of mucin, contributing to the disruption of the gastric mucosal mucus via the overactivation of caspase- 3 and further release of proapoptotic factors; the process is regulated by ERK and p38 kinase [190]. LPS also contributes to the secretion of excessive amounts of pepsinogen [191]. Another virulence mechanism of LPS includes the capability to stimulate bacterial adherence and colonization within the gastric mucosa via LPS interaction with the trefoil factor family (TFF) protein TFF1 [192]. LPS is involved in the activation of the JAK/STAT pathways significantly promoting gastric carcinogenesis; the mechanisms include direct LPS-related phosphorylation of JAK1, JAK2, and STAT3 or indirect upregulation of JAK and STAT members via miR-375 and miR-106b inhibition [193].

\section{Blood Group Antigen-Binding Adhesin}

Blood group antigen-binding adhesin (BabA) is a virulence factor that enables $\mathrm{H}$. pylori adherence to the gastric epithelium and delivery of toxins (such as CagA or VacA) or other virulence factors into the host cells, promoting either direct or indirect damage of host tissues via inflammatory or immune responses. It was proposed that BabA expression in gastric tissue samples might constitute a biomarker of H. pylori infection [194]. The expression of the $b a b A$ gene is strongly associated with the presence of $\operatorname{cag} A$ in particular H. pylori strains; it also depends on the particular geographic area where specific strains are more or less prevalent $[195,196]$. Furthermore, the co-expression of $b a b A, c a g A$, and vacA might contribute to the onset and progression of paraneoplastic gastric lesions as well as 
other gastrointestinal disorders. BabA, CagA, and VacA present a synergy, worsening the severity and clinical outcome of the gastritis patients [197]. Apart from bacterial adherence and colonization, BabA stimulates several immune responses such as granulocyte infiltration or a release of IL-8 enhancing gastric inflammation [198]. Expression of BabA by H. pylori strains is significantly associated with the onset, progression, as well as severity, and clinical outcome of several gastrointestinal diseases such as peptic ulcer disease or GC [199]. BabA expression also correlates with greater mucosal inflammation.

$\mathrm{BabA}$ adheres to H-type 1 and $\mathrm{ABO} /$ Lewis $\mathrm{b}\left(\mathrm{Le}^{\mathrm{b}}\right.$ ) blood group antigens expressed in the gastric epithelium facilitating TSS4 activity, releasing excessive amounts of the pro-inflammatory factors stimulating carcinogenesis [200-203]. Furthermore, H. pylori binding to MUC5AC mucin in the gastric epithelium is also BabA-dependent [204]. BabAstimulated increased TSS4 activity is associated with more severe inflammation, development of intestinal metaplasia, and malignant transformations [205]. BabA is primarily detected in H. pylori strains obtained from symptomatic patients (with GC or duodenal ulcer disease). BabA is capable of binding to its receptors both in the mucosa of the oral cavity and gastric mucosa. It was demonstrated that there is a relationship between BabA expression and the severity of gastritis in the gastric antrum [206]. Saberi et al. (2016) showed that $\mathrm{H}$. pylori strains with low BabA expression and decreased capability of binding to the $\mathrm{Le}^{\mathrm{b}}$ can be detached from the gastric mucus and stimulate ulceration within the duodenum, increasing the risk of peptic ulcer disease [207]. Moreover, low BabA levels are more likely to induce more severe and chronic gastrointestinal diseases, compared to strains with high BabA expression. BabA-expressing H. pylori strains are capable of inducing histological alterations within the gastric mucosa and stimulate the infiltration of inflammatory mediators; there are no differences between BabA-positive and -negative strains in terms of colonization properties [208]. The co-expression of $b a b A$ and cagA genes, as well as bacterial coccoid form, significantly affect the severity of gastritis [209]. Furthermore, BabA expression is more prevalent in CagA-positive H. pylori strains compared to CagA-negative strains [210]. BabA along with sialic acid-binding adhesion (SabA) enables H. pylori adherence to the spasmolytic polypeptide-expressing metaplasia (SPEM) glands, promoting metaplastic alterations that contribute to the onset of carcinogenesis [211].

\section{Sialic Acid-Binding Adhesin}

Sialic acid-binding adhesin (SabA) is an adhesin belonging to the outer membrane protein (OMP) family that facilitates $\mathrm{H}$. pylori adherence to gastric epithelial cells via binding to the $\mathrm{Le}^{\mathrm{x}}$ antigen. It is estimated that SabA is present in approximately $40 \%$ of H. pylori strains. SabA expression is significantly increased during bacterium-induced inflammation within the gastric microenvironment. Enhanced expression of OMPs including SabA, BabA, and OipA is associated with the modulation of gastrointestinal disorders. The expression of SabA is associated with the progression of gastric diseases, excessive neutrophil infiltration, and gastric atrophy during infection; furthermore, there is a relationship between SabA expression and the extent of bacterial colonization [212,213]. There is a relationship between SabA expression and severe intestinal metaplasia, gastric atrophy, as well as further gastric carcinogenesis [214]. Except for the stimulation of neutrophil infiltration, SabA presents a capability to activate human neutrophils as well (through the selectin mimicry), contributing to persistent inflammation via the induction of oxidative damage [215]. Furthermore, SabA can be stimulated by H. pylori neutrophil-activating protein (NAP) [216]. Similarly to BabA, SabA, along with OipA, are considered to improve diagnostic accuracy; thus, they could potentially act as diagnostic biomarkers of active H. pylori infection and H. pylori-induced GC [217]. The enhanced expression of the saba gene was demonstrated to be one of the triggers that induce an iron deficiency in H. pylori-infected patients [218]. Furthermore, it was shown that iron deficiency might further promote the overexpression of saba. Genetic diversity of the saba gene depends on particular geographical origin; moreover, a particular genotype might influence the clinical outcome of H. pylori-infected patients [219]. 


\section{Outer Inflammatory Protein A}

Outer inflammatory protein A (OipA), encoded by the hopH gene, belongs to the OMPs family and as an $\mathrm{H}$. pylori virulence factor, it is strongly associated with the bacterial adherence, colonization, induction, and progression of gastrointestinal disorders, and might affect the clinical outcome of the infected patients [220]. OipA-positive H. pylori strains are more prone to induce much more severe inflammation in gastric mucosa compared to OipA-negative strains. Binding of the OipA to the gastric epithelial cells activates the apoptotic cascade in the host cells primarily via the Bcl-2 family pathway and increased levels of Bax and intracellular cleaved-caspase 3 [221]. Damage induced by OipA presence is usually correlated with a greater risk of GC onset or peptic as well as duodenal ulcer disease and depends on the duration of infection and a dose of $\mathrm{H}$. pylori $[222,223]$. The synthesis of CagA and VacA is believed to be regulated by OipA expression [224]. OipA is more prevalently detected in the gastric biopsy specimens obtained from patients with gastric precancerous lesions than those with gastritis alone. OipA promotes the secretion of numerous pro-inflammatory cytokines such as IL-1, IL-6, IL-8, IL-11 IL-17, matrix metalloproteinase 1 (MMP-1), tumor necrosis factor $\alpha$ (TNF- $\alpha$ ), or RANTES [225-230]. It was reported that OipA might regulate $\beta$-catenin levels [231]. OipA suppresses the maturation of the dendritic cells by downregulating CD40, CD86, and MHC-II expression on the cell surface, as well as the release of IL-10 [232]. The synergistic activity between the virulence factors was presented in $\mathrm{H}$. pylori strains that co-express the oipa gene with caga, and vaca [233]. OipA is involved in the translocation of CagA into the host gastric epithelial cells; this finding might be an explanation of why CagA-positive H. pylori strains usually express high amounts of Oipa $[234,235]$. OipA significantly increases the miR-30b levels affecting the miR-30b/xCT pathway and a further decrease in glutamate levels that stimulate $\mathrm{H}$. pylori-induced damage [236].

\section{Duodenal Ulcer Promoting Gene A}

Duodenal ulcer promoting gene A (DupA) is the H. pylori virulence factor where pathogenicity is associated with the induction of duodenal ulcers as well as the risk of gastritis; nevertheless, DupA expression is negatively correlated with the risk of GC $[237,238]$. Moreover, DupA is even considered to be a protective factor preventing gastric carcinogenesis [239]. Although, Takahashi et al. (2013) showed that long-type dupa strains might contribute to GC via previously induced gastritis [240]. Interestingly, particular DupApositive $\mathrm{H}$. pylori strains do not always increase the risk of duodenal ulcers [241]. There is no association between DupA expression and the presence of other virulence factors such as CagA or VacA. DupA does not trigger bacterial adherence to gastric epithelial cells as well as the delivery of toxins to the host cells; however, the dupa gene is considered to be involved in the formation of T4SS [242]. The prevalence of DupA expression in $\mathrm{H}$. pylori strains is estimated at $45 \%$ and significantly differs depending on the geographic area and the investigated ethnic groups $[243,244]$. A complete dupa cluster enables a greater infiltration of the inflammatory cells and is generally associated with greater virulence compared to strains with an incomplete dupa cluster [245]. DupA stimulates urease and IL-8 secretion primarily in the antrum contributing to the induction of gastritis; stimulation of the pro-inflammatory cytokine release by DupA also increases the risk of duodenal ulcers [246,247]. Furthermore, DupA facilitates inflammation within the antral mucosa and decreases corpus atrophy [248]. Except for IL-8 secretion, DupA triggers IL-12 (IL-12p40 and IL12-p70) production and secretion from the monocytes [249,250]. Contrarily to other H. pylori virulence factors, DupA inhibits the proliferation and growth of GC cells, preventing further carcinogenesis primarily via the overactivation of the mitochondriamediated apoptotic pathway as well as high tolerance of DupA-positive strains to the acidic gastric microenvironment [251]. Infection by the DupA-positive strains might decrease the severity of $\mathrm{H}$. pylori-related gastrointestinal pathologies and provide better clinical outcomes of patients. Furthermore, DupA stimulates gastric acid secretion, which was demonstrated by the presence of higher serum gastrin levels in patients infected by DupA- 
positive strains [252]. DupA is also associated with a greater failure of $\mathrm{H}$. pylori eradication therapies [253]. It is also considered to be a diagnostic marker of H. pylori-related gastrointestinal diseases; so far, the dupa gene without premature stop codons or the 112 bp region of H. pylori DupA specifically could act as potential candidates [254-258].

\section{Adherence-Associated Lipoprotein A and B}

Adherence-associated lipoprotein $\mathrm{A}$ and $\mathrm{B}(\mathrm{AlpA} / \mathrm{AlpB})$ are proteins involved in $\mathrm{H}$. pylori adherence to the gastric epithelial cells and further stimulation of bacterial colonization [259-261]. AlpA/B-deficient H. pylori mutants show significantly decreased capability to bind to the gastric epithelial cells compared to strains that express high levels of AlpA/B [262]. AlpA/B neither present toxic activity itself nor cross-react with human tissue antigens [263]. AlpA/B can be isolated from different $H$. pylori strains independently of geographic localization. AlpA/B can also regulate the release of several cytokines and pro-inflammatory factors including IL-6 and IL-8 and might be involved in the activation of the ERK, c-Fos, and CREB pathways; some of the AlpA/B genotypes might affect JNK and NF- $\kappa B$ pathways as well [262]. It was demonstrated that AlpB is involved in the formation of the bacterial biofilm [264]. Even though AlpA/B might promote H. pylori adherence, the lack of AlpA/B expression results in the enhanced inflammatory responses and more severe inflammation [265].

\section{LacdiNAc-Specific Adhesin}

LacdiNAc-specific adhesin (LabA) is an adhesin that facilitates $\mathrm{H}$. pylori binding to the gastric epithelial cells via the recognition of the LacdiNAc $\left(\mathrm{N}, \mathrm{N}^{1}\right.$-diacetyllactosdiamine/ GalNAcb4GlcNAc, LDN) determinant [266,267]. LabA is so far poorly characterized and more research should be done in order to assess its involvement and relevance in H. pylori-mediated pathogenicity.

\section{Helicobacter pylori Outer Membrane Protein $Q$}

Helicobacter pylori outer membrane protein Q (HopQ) is a virulence factor relevant in bacterial survival in the gastric acidic microenvironment as well as the adherence to gastric epithelial cells, colonization, and further progression of gastrointestinal ailments. Two major types of HopQ can be distinguished-type 1 and 2-where expression might influence GC onset and progression in H. pylori-infected individuals. Generally, HopQ type 1 is present in the majority of H. pylori strains, which also possess cagPAI [268]. The genotype diversity of HopQ is associated with different severity of $\mathrm{H}$. pylori-induced gastrointestinal pathologies; type 1 HopQ is relatively more often found in CagA and s1-VacA-positive strains, increasing the risk of peptic ulcer disease $[269,270]$. Furthermore, HopQ type 1 facilitates the infiltration of pro-inflammatory cells and increases gastric mucosal atrophy [271]. The HopQ type 2 genotype is rather more prevalent in CagA-negative s2-VacA-positive strains [272]. HoQ expression depends on a particular geographic area and ethnic differences and was reported to be associated with different clinical outcomes of patients. HopQ type 2 is rather associated with non-ulcer dyspepsia (NUD) and mild severe gastritis, whereas the presence of both-type 1 and 2-alleles significantly facilitates the risk of NUD. Usually, HopQ type 2 strains are not associated with peptic ulcer disease. The synergy between HopQ and CagA co-expression is recognized as a facilitated activity of several pro-inflammatory pathways, including NF- $\mathrm{kB}$ or those associated with mitogen-activated protein kinases (MAP kinases) via T4SS since HopQ significantly facilitates T4SS activity [273]. The interaction with T4SS and CagA translocation and/or phosphorylation induced by HopQ is stimulated by HopQ binding to host the carcinoembryonic antigenrelated cell adhesion molecules (CEACAM) proteins (primarily CEACAM1, CEACAM3, CEACAM5, and CEACAM6) expressed on gastric epithelial cells promoting NF- $\mathrm{B}$ activation [274-280]. This, as a consequence, might induce the development of gastric ulcers and facilitate gastric carcinogenesis. HopQ-induced CagA translocation is facilitated by HP0231, a major H. pylori thioloxidoreductase [281]. HopQ-CEACAM interactions are 
also crucial for H. pylori survival in neutrophils [282]. Furthermore, HopQ binding to CEACAM1 inhibits natural killer and T cell functions; such interactions are observed during the early stages of tumorigenesis [283]. HopQ-deficient strains present decreased capability to induce pro-inflammatory responses in the host cells as well as fail in CagA translocation [284]. HopQ-CEACAM interactions are considered to be potential therapeutic targets in the prevention and treatment of $\mathrm{H}$. pylori-related gastrointestinal pathologies.

\section{Helicobacter pylori Outer Membrane Protein $Z$}

Helicobacter pylori outer membrane protein Z (HopZ) is another member of the OMPs family where pathogenicity is not clearly described yet compared to other OMPs. HopZ is divided into two variants-HopZ1 and HopZ2 [285]. HopZ facilitates bacterial adherence to gastric epithelial cells and stimulates H. pylori colonization in gastric mucosa; however, the exact site of HopZ binding is still unknown. HopZ pathogenicity is considered to be the most essential during the early stages of $\mathrm{H}$. pylori infection; HopZ disturbs gastric acid secretion and is involved in the transient hypochlorhydria [286].

\section{Induced by Contact with Epithelium Gene $A$}

Induced by contact with epithelium gene A (IceA) is a quite recently discovered virulence factor of $\mathrm{H}$. pylori that is still poorly described. IceA levels significantly increase during $\mathrm{H}$. pylori binding with the gastric epithelial cells. There are two major allelic variants of IceA-IceA1 and IceA2. Since H. pylori possess only one iceA locus, IceA1 or IceA can be expressed and the presence of both indicates infection by several different $\mathrm{H}$. pylori strains. Some researchers demonstrated that there is no relationship between IceA expression and the presence of other virulence factors such as CagA or VacA; however, these data are quite contradictory among authors, thus more research is needed in this field [287-289]. It was shown that the expression of IceA, similarly to other major virulence factors such as CagA or VacA, leads to poorer clinical outcome of the infected patients. Furthermore, IceA status significantly differs depending on particular geographic areas [290]. The expression of IceA increases during $\mathrm{H}$. pylori binding with the gastric epithelial cells and might be associated with the development of peptic ulcer disease [287,290,291]. IceA1 strains are more prone to induce oxidative DNA damage which can be considered as a marker of GC progression or the risk factor related to the development of this malignancy [292,293]. Contrarily, IceA2 expression is more often associated with non-peptic ulcer dyspepsia [294]. IceA1-positive strains are capable of producing significant amounts of pro-inflammatory IL-8, which was not observed in cases of IceA1-negative strains $[295,296]$. Even though IceA1 expression is more prevalent among $\mathrm{H}$. pylori strains, IceA2 presence is associated with greater granulocytic and lymphocytic infiltration, as well as atrophic gastritis [297]. Both allelic variants might facilitate the development of gastritis, gastric ulcers, functional dyspepsia, acute antral inflammation, as well as GC. Moreover, infection by the IceA-2-positive strains stimulates pro-inflammatory IL-1 polymorphisms, which is further associated with a greater risk of the onset and progression of the precancerous lesions in the gastric mucosa. Strains that express IceA, CagA, and VacA s1/m1 at the same time are likely to increase the severity of gastric inflammation [298]. IceA is considered to be a potential biomarker of the severity of gastrointestinal pathologies induced by H. pylori.

\section{Cholesteryl $\alpha$-Glucosyltransferase}

Cholesteryl $\alpha$-glucosyltransferase $(\alpha \mathrm{CgT})$ is a quite poorly characterized enzyme of $\mathrm{H}$. pylori that is involved in the formation of cholesteryl $\alpha$-glucoside ( $\alpha \mathrm{CGL}$ ) by adding $\alpha$-glucosyl to the cholesterol of the host cellular membranes. H. pylori does not synthesize cholesterol on its own but extracts it from the plasma membranes of the host cells; $\alpha \mathrm{CgT}$ is involved in the subsequent glycosylation of the cholesterol. $\alpha \mathrm{CgT}$ is produced by $\mathrm{H}$. pylori in an inactive form which becomes activated after binding to the host cell membrane [299]. The absence of the $\alpha \mathrm{CgT}$ gene is associated with significant dysregulations of the cholesterol uptake by the bacterium [300]. Glucosylation promoted by $\alpha \mathrm{CgT}$ prevents $\mathrm{H}$. pylori from 
the phagocytosis and immune responses induced by bacterial infection [301]. Furthermore, cholesteryl glucosides (CGs) are involved in the regulation of the responses from the $\mathrm{CD}^{+} \mathrm{T}$-cells, as well as the IL-4 and IFN- $\gamma$ pathways [302]. Increased $\alpha \mathrm{CgT}$ expression inhibits IFNG-JAK/STAT1, as well as the IL-6 and IL-22 signaling pathways, resulting in an enhanced bacterial escape from the host inflammatory responses and further progression of gastric carcinogenesis [303]. $\alpha \mathrm{CgT}$ is essential for the CagA translocation and stimulates the excessive secretion of IL-8 [304]. The levels of $\alpha \mathrm{CgT}$ measured from the gastric tissue samples obtained from the $\mathrm{H}$. pylori-infected patients are positively correlated with the atrophy score of the gastric tissues [305]. Thus, it was proposed that greater levels of $\alpha \mathrm{CgT}$ might induce stronger immune responses that eventually lead to more severe $\mathrm{H}$. pyloriinduced inflammation, especially during the early stages of infection. Furthermore, $\alpha \mathrm{CgT}$ also seems to be crucial for proper bacterial growth [306]. As an example, Lee et al. (2006) showed that $\mathrm{H}$. pylori strains deficient in $\alpha \mathrm{CgT}$ result in inhibited growth or even enhanced bacterial lethality [307]. $\alpha$ CgT-positive strains are more likely to survive in the macrophages due to the dysregulated autophagy processes; moreover, $\alpha \mathrm{CgT}$ promotes bacterial survival in the host cells by interrupting autophagosome-lysosome fusion $[308,309]$. H. pylori strains that lack CGs show greater permeability of the cellular walls, decreasing bacterial pathogenic potential [310]. At the same time, the presence of GCs also seems to be crucial in bacterial antibiotic resistance. Therefore, $\alpha \mathrm{CgT}$ might constitute a potential molecular therapeutic target for GC, peptic ulcers, or MALT lymphoma induced by the $\mathrm{H}$. pylori infection.

\section{2. $\gamma$-Glutamyl-Transpeptidase}

$\gamma$-glutamyl-transpeptidase (GGT) is one of the virulent enzymes of H. pylori that stimulates the conversion of glutamine and glutathione into glutamate and ammonia as well as glutamate and cyteinylglycine, respectively. The hydrolysis of the glutamine facilitates the vacuolation process by VacA [311]. GGT promotes the release of ROS (particularly $\mathrm{H}_{2} \mathrm{O}_{2}$ ), inhibition of cellular proliferation, as well as progression of apoptosis and necrosis of the gastric epithelial cells via the excessive secretion of IL-8 (in an NFKB-dependent manner), IL-10, cyclooxygenase-2 (COX-2), inducible iNOS, and epidermal growth factor-related peptides at the same time, resulting in dysregulated cell cycle processes [312-315]. Furthermore, GGT-induced apoptosis is stimulated in a mitochondrial-dependent manner via the release of cytochrome $c$ and further overactivation of the caspase pathway (caspase-3 and -9) [316]. Park et al. (2014) demonstrated that GGT might increase $\mathrm{Ca}^{2+}$ levels through the activation of the phospholipase C-inositol 1,4,5-trisphosphate (PLC-IP3) pathway, eventually enhancing apoptotic processes [317]. Major dysregulations are primarily due to the GGT-dependent cell cycle arrest in the G1 phase with the downregulation of cyclin A and E, Cdk 4 and 6, and the upregulation of p21 with p27 [318,319]. Apoptotic processes and enhanced inflammation were also observed in the case of human biliary cells infected by GGT-positive strains, which indicates that $\mathrm{H}$. pylori GGT might also contribute to the progression of cholangiocarcinoma [320].

GGT stimulates bacterial colonization and persistence in the gastric microenvironment via regulating immune tolerance by inhibiting CD4-positive T-cell proliferation, facilitating $\mathrm{CD}^{+}$cells infiltration into the gastric microenvironment, and preventing differentiation of the dendritic cells, triggering alterations in their phenotype into the tolerogenic one [321-324]. GGT overload downregulates major pathways crucial for proper T-cell functioning such as cMyc or interferon regulatory factor 4 (IRF4) and disrupts T-cell proliferation by inhibiting CD25 expression and IL-2 release [325]. GGT-negative H. pylori mutants fail in colonizing the gastric epithelium efficiently [326,327]. Furthermore, GGT is crucial for proper bacterial growth as GGT inhibition results in growth retardation [328]. GGT acts synergistically with other virulence factors such as VacA, inhibiting CD25 and CD69 expression and decreasing IL-2, IL-4, IL-10, and IFN- $\gamma$ levels; IFN- $\gamma$ levels are highly dependent on GGT activity [302]. Impaired and dysregulated immune responses stimulated by GGT might further contribute to the progression of gastric carcinogenesis. Since GGT is involved in 
DNA damage as well as cellular hyperproliferation, these processes might significantly contribute to the progression of gastric epithelial cells into the malignant phenotype [329]. GGT-positive H. pylori strains also show an ability to reduce cell viability and promote the loss of survivin [330]. Apart from gastric carcinogenesis, GGT might contribute to the onset and progression of peptic ulcer disease as well [331].

\section{Neutrophil-Activating Protein}

Neutrophil-activating protein (NAP) is an H. pylori virulence factor that stimulates neutrophil adherence to the gastric epithelial cells, promoting the production of ROS as well as myeloperoxidase primarily during the stationary phases of infection. NAP activates the neutrophils and mast cells as well as promotes monocytes migration. Neutrophils are primarily stimulated due to the overactivation of the ERK and p38-MAPK pathways [332]. NAP presents pro-inflammatory activities and is highly involved in the progression of inflammation and tissue damage during $\mathrm{H}$. pylori infection. NAP shows structural similarity to ferritin and belongs to the DNA-protecting protein under severe conditions (Dps) family. It presents ferroxidase activity however, without directly binding to it; due to the presence of the ferroxidase center, NAP incorporates $\mathrm{Fe} 2+$ ions that are further oxidized to $\mathrm{Fe} 3+$ and the whole process results in hydroxyl radicals that protect $\mathrm{H}$. pylori DNA from damage [333]. Except for iron ions, NAP presents an ability to store other ions such as zinc or cadmium [334].

NAP stimulates the infiltration of monocytes and polymorphonuclear granulocytes as well as the surface expression of $\beta 2$-integrins; furthermore, it stimulates the human blood mononuclear cells to secrete tissue factor (TF) and plasminogen activator inhibitor-2 (PAI-2), leading to the imbalance between coagulation and fibrinolysis [335]. Moreover, NAP induces the release of several chemokines such as interleukin-8 (IL-8), MIP- $1 \alpha$ or CCL3, and MIP-1 $\beta$ (CCL4) from the neutrophils, tumor necrosis factor alpha (TNF- $\alpha$ ), IL-6, and IL- 8 by monocytes, along with the release of $\beta$-hexosaminidase and IL- 6 by mast cells $[336,337]$. NAP prolongs the myeloid cells' activation by protecting them from apoptosis by increasing the amounts of the anti-apoptotic proteins of the Bcl-2 family [338]. One of the most prominent NAP functions is the ability to stimulate the neutrophils activation, inducing a further release of IL-12 and IL-23 that facilitate Th- 1 immune responses, with the excessive release of IFN- $\gamma$ at the same time inhibiting Th- 2 responses [335,339-342].

The release of the above-mentioned factors significantly increases the secretion of gastrin and pepsinogen and subsequent damage to the gastric mucosa. These alterations might contribute to the progression of chronic gastritis via the disrupted processes of fibrin removal and further impaired healing processes. Furthermore, NAP stimulates the mast cells to secrete $\beta$-hexosaminidase and IL-6, facilitating a pro-inflammatory cascade [343]. Its involvement in the maintenance of chronic inflammation is also observed as a NAP-induced Ag-specific T cells overactivation and intensification of the dendritic cells' maturation and subsequent migration [344]. One of the hypotheses regarding NAP functions is its binding to the iron. However, its importance in inflammation is also presented by impairing the epithelial tight junctions and basal membranes within the gastric mucosa; it is also believed to stimulate the release of nutrients providing $\mathrm{H}$. pylori growth during infection $[345,346]$. NAP also facilitates $\mathrm{H}$. pylori survival by its contribution to DNA protection [347].

\section{High Temperature Requirement A}

High temperature requirement $\mathrm{A}(\mathrm{Htr} \mathrm{A})$ is an $\mathrm{H}$. pylori serine protease that targets E-cadherin on the gastric epithelial cells, leading to the cleavage of the E-cadherin extracellular domain and subsequent impairments in epithelial barrier functions [348-350]. HtrA primarily disturbs two types of junctions within the epithelium adherens junctions (Ecadherin) and tight junctions (occludin and claudin-8), as well as some of the extracellular matrix proteins, including aggrecan, proteoglycans, and fibronectin [351]. HtrA is localized in the H. pylori OMVs. Several studies reported that inhibition of H. pylori HtrA results in 
the blockage of H. pylori passage through the gastric epithelium as well as the reduced number of alterations within the gastric epithelial cells [352,353]. HtrA might increase H. pylori migration properties even up to 2.2-fold when compared to HtrA-negative species [354]. The transport of this virulence factor into the periplasm is provided by the presence of the signal peptide responsible for Sec-dependent transport through the inner membrane. Apart from H. pylori transmigration through the gastric epithelium, HtrA plays a role in CagA injection into the host cells by interacting with the $\alpha 5 \beta 1$ receptor [355]. HtrA expression is significantly increased in low $\mathrm{pH}$ and under stress conditions. The $h t r A$ gene is highly prevalent in numerous $\mathrm{H}$. pylori strains regardless of the geographic areas. What is intriguing is that HtrA inhibition might be lethal for $\mathrm{H}$. pylori strains, indicating that it constitutes a pivotal virulence factor of $\mathrm{H}$. pylori; zinc and copper ions were presented to be effective inhibitors of the HtrA activity [356,357]. Moreover, excessive amounts of calcium ions seem to prevent the HtrA-related E-cadherin cleavage along with the additional stabilization of the junctions [358]. Furthermore, H. pylori strains that are deprived of HtrA are much more sensitive to particular conditions, including elevated temperature, osmotic shock, or treatment with puromycin [359,360]. Indeed, HtrA constitutes a crucial protective factor that prevents $\mathrm{H}$. pylori from numerous stress conditions, enabling effective bacterial colonization within the gastric mucosa. HtrA is suspected to be one of the potential factors that might induce EMT and further tumorigenesis; however, so far, there is not sufficient data to provide an ultimate confirmation of this phenomenon.

\section{Heat Shock Proteins}

Heat shock proteins (Hsps) constitute a family of proteins that act as molecular chaperones, being responsible for the maintenance of proper structural and functional properties of the cellular proteins. Except for the above-mentioned chaperoning role, Hsps also regulate apoptosis, autophagy, immunity, inflammation, carcinogenesis, as well as the protection against oxidative stress. There are three major Hsps expressed by H. pyloriHspB (Hsp60), HspA (Hsp10), and Hsp70-and their expression is regulated by two major repressors-HspR and HrcA. HspB affects the Nrf2/Keap1 pathway, inhibiting Nrf2 translocation, subsequent increased release of COX-2, IL-8, and metalloproteinases (MMP3 and MMP7), and enhanced inflammatory responses [361]. HspA is crucial for proper urease activation during $\mathrm{H}$. pylori infection. HspA of $\mathrm{H}$. pylori shares approximately $50 \%$ similarity to human homologues of Hsp60 [362]. HspA binds to the nickel ions as well as bismuth; thus, it might constitute a potential molecular target for potential anti-ulcer drugs [363]. HspA60-mediated inflammation within the gastric mucosa is due to its interactions with the TLR and further overactivation of the NF- $\mathrm{KB}$, ERK, and MAP kinase (MAPK) signaling pathways with a subsequent IL- 8 and TNF- $\alpha$ secretion from the monocytic cells [364-367]. Macrophages are stimulated by Hsp60 to release the IL-6 due to the overactivation of the NF- $\mathrm{KB}$ pathway as well as IL-10 and TGF- $\beta$ that stimulate the proliferation of Treg cells promoting inflammation [368,369]. Furthermore, Hsp60 is involved in $\mathrm{H}$. pylori adherence and further colonization within the gastric epithelium. The C-terminal domain of HspA was reported to play a role in nickel sequestration and detoxification and since nickel homeostasis is crucial for $\mathrm{H}$. pylori colonization, this virulence factor might act as a potential molecular target for H. pylori eradication [370]. H. pylori motility is highly associated with the expression of Hsps inhibitors-HspR and HrcA [371]. It was demonstrated that HspA seropositivity increases with an individual's age [372]. Hsp60 diffuses from the H. pylori into the gastric epithelial cells, leading to persistent bacterial infection, inflammation, and subsequent carcinogenesis via the enhancement of tumor cell migration and angiogenesis. Hsp60-mediated angiogenesis is primarily promoted by the CXCR2/PLCb2/Ca2+ signaling pathways in gastric epithelial cells [373]. Hsp60 might also constitute a potential predicting factor concerning $\mathrm{H}$. pylori eradication on the gastric MALT lymphoma [374-376]. Furthermore, the cross-reactions of Hsps, e.g., between the human Hsp60 and bacterial HspB, are common and they significantly facilitate the onset of gastrointestinal diseases [362]. Apart from the Hsps that are expressed by H. pylori, 
bacterial colonization in the gastric mucosa significantly decreases the expression of host Hsps such as Hsp70 or Hsp90, and at the same time increases Hsp32 and Hsp27 levels, which additionally increases the susceptibility to further damage [377-381].

\section{Conclusions}

This review provides an insight into the virulence of $\mathrm{H}$. pylori and its impact on the gastric microenvironment in the current state of knowledge. Colonization of different $\mathrm{H}$. pylori strains in the same individual at the same time indicates that $\mathrm{H}$. pylori is capable of inducing various genetic alterations and the expression of numerous virulence factors during its colonization period. Specific virulence factors are associated with the severity of symptoms and the clinical outcome of the infected patients. Several bacterial antigens such as BabA, SabA, OipA, AlpA, DupA, GGT, NAP, catalase, or Hsp60 are considered to be potential candidates for vaccines that might elicit both humoral and cellular immune responses during the infection. H. pylori elicits numerous adaptive mechanisms that enable effective bacterial adherence, colonization, and cellular alterations that provide the induction of further premalignant changes in the gastric microenvironment. Even though $\mathrm{H}$. pylori virulence factors might act synergistically, some of them are crucial in bacterial colonization and thus chronic infection, whereas others might only act as additional triggers that only stimulate further responses. Therefore, more research regarding the $\mathrm{H}$. pylori structure and virulence as well as their association with gastrointestinal diseases is needed.

Funding: This research received no external funding.

Conflicts of Interest: The authors declare no conflict of interest.

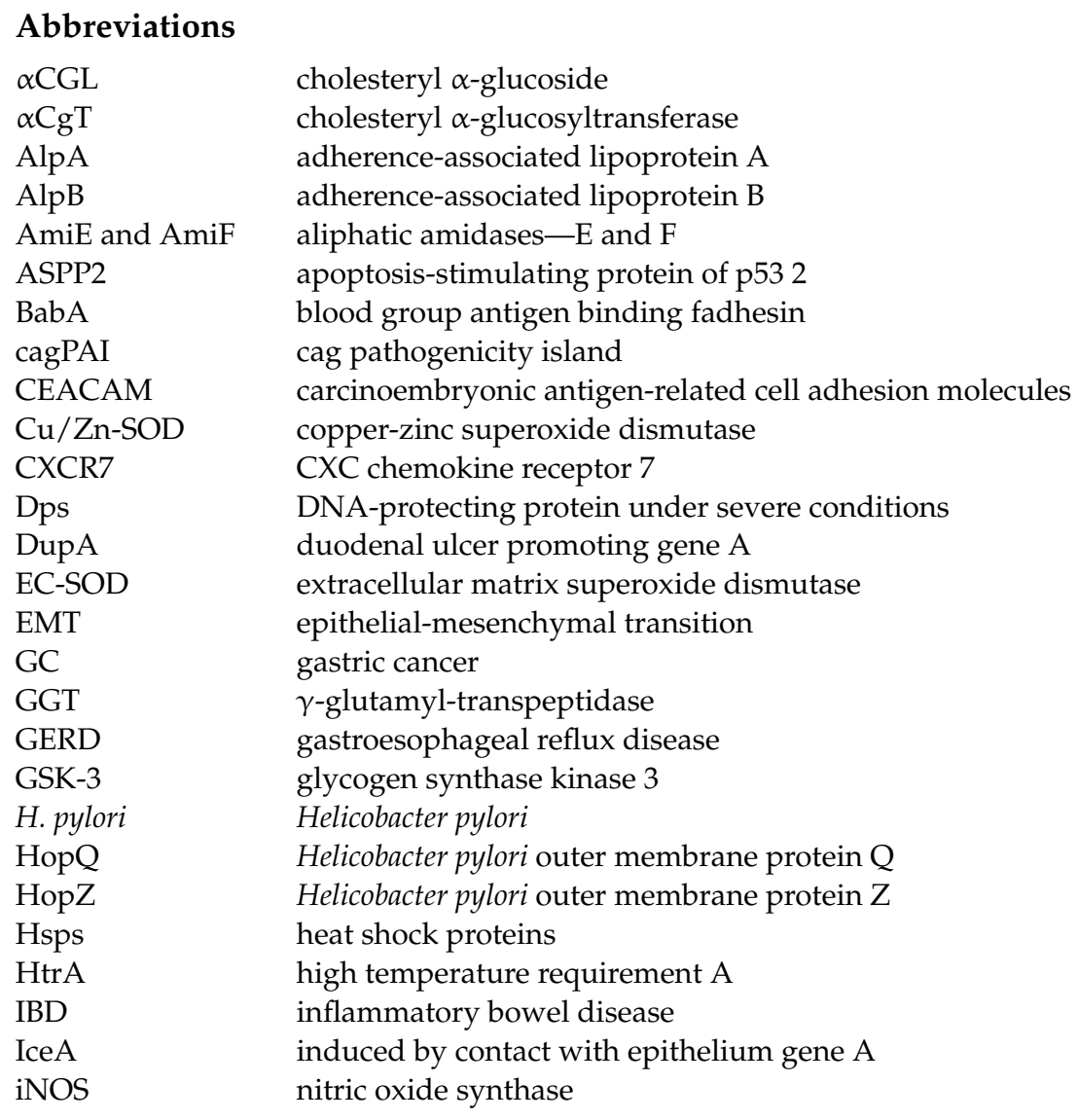




\begin{tabular}{|c|c|}
\hline LabA & LacdiNAc-specific adhesin \\
\hline (Le) antigens & Lewis antigens \\
\hline LPS & lipopolysaccharide \\
\hline LRP-1 & lipoprotein receptor-related protein-1 \\
\hline MALT & mucosa-associated lymphoid tissue lymphoma \\
\hline MAP & mitogen-activated protein \\
\hline MAPK & mitogen-activated protein kinase \\
\hline MD-2 & myeloid differential protein-2 \\
\hline $\mathrm{MHC}$ & major histocompatibility complex \\
\hline MMP-1 & matrix metalloproteinase 1 \\
\hline Mn-SOD & manganese superoxide dismutase \\
\hline Mox1 & mitogen oxidase 1 \\
\hline NAP & neutrophil-activating protein \\
\hline NUD & non-ulcer dyspepsia \\
\hline OipA & outer inflammatory protein A \\
\hline OMP & outer membrane protein \\
\hline OMPLA & outer membrane phospholipase A \\
\hline OMVs & outer membrane vesicles \\
\hline PAI-2 & plasminogen activator inhibitor-2 \\
\hline PD-1 & programmed death-ligand 1 \\
\hline PDCD4 & programmed cell death protein 4 \\
\hline $\mathrm{PLA}_{1}$ & phospholipase A1 \\
\hline $\mathrm{PLA}_{2}$ & phospholipase A2 \\
\hline PLC & phospholipase C \\
\hline PLC-IP3 & phospholipase C - inositol 1,4,5-trisphosphate \\
\hline PLD & phospholipase D \\
\hline ROS & reactive oxygen species \\
\hline $\operatorname{RPTP} \alpha$ & receptor-like protein tyrosine phosphatases $\beta$ \\
\hline $\mathrm{RPTP} \beta$ & receptor-like protein tyrosine phosphatases $\alpha$ \\
\hline RUNX3 & run-related transcription factor 3 \\
\hline SabA & sialic acid-binding adhesin \\
\hline SOD & superoxide dismutase \\
\hline T4SS & type 4 secretion system \\
\hline TF & tissue factor \\
\hline TFF & trefoil factor family \\
\hline TGF- $\beta 1$ & transforming growth factor-beta 1 \\
\hline TLR4 & toll-like receptor 4 \\
\hline TNF- $\alpha$ & tumor necrosis factor alpha \\
\hline VacA & vacuolating cytotoxin \\
\hline $\mathrm{Vn}$ & vitronectin \\
\hline WHO & World Health Organization \\
\hline YAP & yes-associated protein \\
\hline
\end{tabular}

\section{References}

1. Ishaq, S.; Nunn, L. Helicobacter pylori and gastric cancer: A state of the art review. Gastroenterol. Hepatol. Bed Bench 2015, 8, S6-S14. [PubMed]

2. International Agency for Research on Cancer (IARC). Schistosomes, Liver Flukes and Helicobacter pylori; IARC: Lyon, France, 1994; pp. 1-241.

3. Burucoa, C.; Axon, A. Epidemiology of Helicobacter pylori infection. Helicobacter 2017, 22, e12403. [CrossRef] [PubMed]

4. Pucułek, M.; Machlowska, J.; Wierzbicki, R.; Baj, J.; Maciejewski, R.; Sitarz, R. Helicobacter pylori associated factors in the development of gastric cancer with special reference to the early-onset subtype. Oncotarget 2018, 9, 31146-31162. [CrossRef] [PubMed]

5. Ansari, S.; Yamaoka, Y. Survival of Helicobacter pylori in gastric acidic territory. Helicobacter 2017, 22, e12386. [CrossRef] [PubMed]

6. Ciaula, A.D.; Baj, J.; Garruti, G.; Celano, G.; Angelis, M.D.; Wang, H.H.; Di Palo, D.M.; Bonfrate, L.; Wang, D.Q.H.; Portincasa, P. Liver Steatosis, Gut-Liver Axis, Microbiome and Environmental Factors. A Never-Ending Bidirectional Cross-Talk. J. Clin. Med. 2020, 9, 2648. [CrossRef]

7. Machlowska, J.; Baj, J.; Sitarz, M.; Maciejewski, R.; Sitarz, R. Gastric Cancer: Epidemiology, Risk Factors, Classification, Genomic Characteristics and Treatment Strategies. Int. J. Mol. Sci. 2020, 21, 4012. [CrossRef] 
8. Oleastro, M.; Ménard, A. The Role of Helicobacter pylori Outer Membrane Proteins in Adherence and Pathogenesis. Biology 2013, 2, 1110-1134. [CrossRef]

9. Banic, M.; Franceschi, F.; Babic, Z.; Gasbarrini, A. Extragastric manifestations of Helicobacter pylori infection. Helicobacter 2012, 17, 49-55. [CrossRef]

10. González, C.; Megraud, F.; Buissonniere, A.; Lujan Barroso, L.; Agudo, A.; Duell, E.J.; Boutron-Ruault, M.C.; Clavel-Chapelon, F.; Palli, D.; Krogh, V.; et al. Helicobacter pylori infection assessed by ELISA and by immunoblot and noncardia gastric cancer risk in a prospective study: The Eurgast-EPIC project. Ann. Oncol. 2012, 23, 1320-1324. [CrossRef]

11. Machlowska, J.; Kapusta, P.; Baj, J.; Morsink, F.H.M.; Wołkow, P.; Maciejewski, R.; Offerhaus, G.J.A.; Sitarz, R. High-Throughput Sequencing of Gastric Cancer Patients: Unravelling Genetic Predispositions Towards an Early-Onset Subtype. Cancers 2020, 12, 1981. [CrossRef]

12. Baj, J.; Brzozowska, K.; Forma, A.; Maani, A.; Sitarz, E.; Portincasa, P. Immunological Aspects of the Tumor Microenvironment and Epithelial-Mesenchymal Transition in Gastric Carcinogenesis. Int. J. Mol. Sci. 2020, 21, 2544. [CrossRef] [PubMed]

13. Baj, J.; Korona-Głowniak, I.; Forma, A.; Maani, A.; Sitarz, E.; Rahnama-Hezavah, M.; Radzikowska, E.; Portincasa, P. Mechanisms of the Epithelial-Mesenchymal Transition and Tumor Microenvironment in Helicobacter pylori-Induced Gastric Cancer. Cells 2020, 9, 1055. [CrossRef] [PubMed]

14. Watari, J. Helicobacter pyloriassociated chronic gastritis, clinical syndromes, precancerous lesions, and pathogenesis of gastric cancer development. World J. Gastroenterol. 2014, 20, 5461. [CrossRef] [PubMed]

15. Potamitis, G.S.; Axon, A.T.R. Helicobacter pylori and Nonmalignant Diseases. Helicobacter 2015, 20, 26-29. [CrossRef] [PubMed]

16. Lanas, A.; Chan, F.K.L. Peptic ulcer disease. Lancet 2017, 390, 613-624. [CrossRef]

17. Bravo, D.; Hoare, A.; Soto, C.; Valenzuela, M.A.; Quest, A.F. Helicobacter pylori in human health and disease: Mechanisms for local gastric and systemic effects. World J. Gastroenterol. 2018, 24, 3071-3089. [CrossRef] [PubMed]

18. Pucułek, M.; Baj, J.; Portincasa, P.; Sitarz, M.; Grochowski, C.; Radzikowska, E. The morphology and application of stem cells in digestive system surgery. Folia Morphol. 2020, 11. [CrossRef] [PubMed]

19. Scott, D.R.; Weeks, D.; Hong, C.; Postius, S.; Melchers, K.; Sachs, G. The role of internal urease in acid resistance of Helicobacter pylori. Gastroenterology 1998, 114, 58-70. [CrossRef]

20. Sidebotham, R.L.; Worku, M.L.; Karim, Q.N.; Dhir, N.K.; Baron, J.H. How Helicobacter pylori urease may affect external pH and influence growth and motility in the mucus environment. Eur. J. Gastroenterol. Hepatol. 2003, 15, 395-401. [CrossRef]

21. Can, F.; Karahan, C.; Dolapci, I.; Demirbilek, M.; Tekeli, A.; Arslan, H. Urease Activity and Urea Gene Sequencing of Coccoid Forms of H. pylori Induced by Different Factors. Curr. Microbiol. 2008, 56, 150-155. [CrossRef]

22. Nolan, K.J.; Mcgee, D.J.; Mitchell, H.M.; Kolesnikow, T.; Harro, J.M.; Orourke, J.; Wilson, J.E.; Danon, S.J.; Moss, N.D.; Mobley, H.L.T.; et al. In Vivo Behavior of a Helicobacter pylori SS1 nixA Mutant with Reduced Urease Activity. Infect. Immun. 2002, 70, 685-691. [CrossRef] [PubMed]

23. Schmalstig, A.A.; Benoit, S.L.; Misra, S.K.; Sharp, J.S.; Maier, R.J. Noncatalytic Antioxidant Role for Helicobacter pylori Urease. J. Bacteriol. 2018, 200, e00124-18. [CrossRef] [PubMed]

24. Wassermann, G.E.; Olivera-Severo, D.; Uberti, A.F.; Carlini, C.R. Helicobacter pylori urease activates blood platelets through a lipoxygenase-mediated pathway. J. Cell. Mol. Med. 2010, 14, 2025-2034. [CrossRef] [PubMed]

25. Olivera-Severo, D.; Uberti, A.F.; Marques, M.S.; Pinto, M.T.; Gomez-Lazaro, M.; Figueiredo, C.; Leite, M.; Carlini, C.R. A new role for Helicobacter pylori urease: Contributions to angiogenesis. Front. Microbiol. 2017, 8, 1883. [CrossRef] [PubMed]

26. Belzer, C.; Stoof, J.; Beckwith, C.S.; Kuipers, E.J.; Kusters, J.G.; Vliet, A.H.M.V. Differential regulation of urease activity in Helicobacter hepaticus and Helicobacter pylori. Microbiology 2005, 151, 3989-3995. [CrossRef] [PubMed]

27. Bauerfeind, P.; Garner, R.; Dunn, B.E.; Mobley, H.L. Synthesis and activity of Helicobacter pylori urease and catalase at low pH. Gut 1997, 40, 25-30. [CrossRef] [PubMed]

28. Ghalehnoei, H.; Ahmadzadeh, A.; Farzi, N.; Alebouyeh, M.; Aghdaei, H.A.; Azimzadeh, P.; Molaei, M.; Zali, M.R. Relationship between ureB Sequence Diversity, Urease Activity and Genotypic Variations of Different Helicobacter pylori Strains in Patients with Gastric Disorders. Pol. J. Microbiol. 2016, 65, 153-159. [CrossRef]

29. Mcgee, D.J.; Coker, C.; Testerman, T.L.; Harro, J.M.; Gibson, S.V.; Mobley, H.L.T. The Helicobacter pylori flbA flagellar biosynthesis and regulatory gene is required for motility and virulence and modulates urease of $\mathrm{H}$. pylori and Proteus mirabilis. J. Med. Microbiol. 2002, 51, 958-970. [CrossRef]

30. Tarsia, C.; Danielli, A.; Florini, F.; Cinelli, P.; Ciurli, S.; Zambelli, B. Targeting Helicobacter pylori urease activity and maturation: In-cell high-throughput approach for drug discovery. Biochimica et Biophysica Acta (BBA). Gen. Subj. 2018, 1862, $2245-2253$. [CrossRef]

31. Suerbaum, S. The complex flagella of gastric Helicobacter species. Trends Microbiol. 1995, 3, 168-170. [CrossRef]

32. Geis, G.; Suerbaum, S.; Forsthoff, B.; Leying, H.; Opferkuch, W. Ultrastructure and biochemical studies of the flagellar sheath of Helicobacter pylori. J. Med. Microbiol. 1993, 38, 371-377. [CrossRef] [PubMed]

33. Martínez, L.E.; Hardcastle, J.M.; Wang, J.; Pincus, Z.; Tsang, J.; Hoover, T.R.; Bansil, R.; Salama, N.R. Helicobacter pyloristrains vary cell shape and flagellum number to maintain robust motility in viscous environments. Mol. Microbiol. 2015, 99, 88-110. [CrossRef] [PubMed]

34. Merkx-Jacques, A.; Obhi, R.K.; Bethune, G.; Creuzenet, C. The Helicobacter pylori flaA1 and wbpB Genes Control Lopopolysaccharide and Flagellum Synthesis and Function. J. Bacteriol. 2004, 186, 2253-2265. [CrossRef] [PubMed] 
35. Kao, C.-Y.; Sheu, B.-S.; Wu, J.-J. CsrA RegulatesHelicobacter pyloriJ99 Motility and Adhesion by Controlling Flagella Formation. Helicobacter 2014, 19, 443-454. [CrossRef] [PubMed]

36. Nakamura, H.; Yoshiyama, H.; Takeuchi, H.; Mizote, T.; Okita, K.; Nakazawa, T. Urease plays an important role in the chemotactic motility of Helicobacter pylori in a viscous environment. Infect. Immun. 1998, 66, 4832-4837. [CrossRef] [PubMed]

37. Yoshiyama, H.; Nakazawa, T. Unique mechanism of Helicobacter pylori for colonizing the gastric mucus. Microb. Infect. 2000, 2, 55-60. [CrossRef]

38. O'Toole, P.W.; Lane, M.C.; Porwollik, S. Helicobacter pylori motility. Microb. Infect. 2000, 2, 1207-1214. [CrossRef]

39. Ottemann, K.M.; Lowenthal, A.C. Helicobacter pylori Uses Motility for Initial Colonization and To Attain Robust Infection. Infect. Immun. 2002, 70, 1984-1990. [CrossRef] [PubMed]

40. Lowenthal, A.C.; Hill, M.; Sycuro, L.K.; Mehmood, K.; Salama, N.R.; Ottemann, K.M. Functional Analysis of the Helicobacter pylori Flagellar Switch Proteins. J. Bacteriol. 2009, 191, 7147-7156. [CrossRef]

41. Lertsethtakarn, P.; Ottemann, K.M.; Hendrixson, D.R. Motility and Chemotaxis in Campylobacter and Helicobacter. Ann. Rev. Microbiol. 2011, 65, 389-410. [CrossRef] [PubMed]

42. $\mathrm{Gu}, \mathrm{H}$. Role of Flagella in the Pathogenesis of Helicobacter pylori. Curr. Microbiol. 2017, 74, 863-869. [CrossRef] [PubMed]

43. Hathroubi, S.; Zerebinski, J.; Ottemann, K.M. The Helicobacter pylori Biofilm Involves a Multi-Gene Stress-Biased Response Including a Structural Role for Flagella. MBio 2018, 9, e01973-18. [CrossRef] [PubMed]

44. Tang, R.X.; Luo, D.J.; Sun, A.H.; Yan, J. Diversity of Helicobacter pylori isolates in expression of antigens and induction of antibodies. World J. Gastroenterol. 2008, 14, 4816-4822. [CrossRef] [PubMed]

45. Skene, C.; Young, A.; Every, A.; Sutton, P. Helicobacter pyloriflagella: Antigenic profile and protective immunity. FEMS Immunol. Med. Microbiol. 2007, 50, 249-256. [CrossRef]

46. Lawson, A.J. Helicobacter. In Manual of Clinical Microbiology, 10th ed.; James, V., Karen, C., Guido, F., Eds.; ASM: Washington, DC, USA, 2011; pp. 900-915.

47. Lee, S.K.; Stack, A.; Katzowitsch, E.; Aizawa, S.I.; Suerbaum, S.; Josenhans, C. Helicobacter pylori flagellins have very low intrinsic activity to stimulate human gastric epithelial cells via TLR5. Microb. Infect. 2003, 5, 1345-1356. [CrossRef] [PubMed]

48. Clyne, M.; Ocroinin, T.; Suerbaum, S.; Josenhans, C.; Drumm, B. Adherence of Isogenic Flagellum-Negative Mutants ofHelicobacter pylori and Helicobacter mustelae to Human and Ferret Gastric Epithelial Cells. Infect. Immun. 2000, 68, 4335-4339. [CrossRef] [PubMed]

49. Raghwan, C.R. Host Cell Contact Induces Fur-dependent Expression of Virulence Factors CagA and VacA inHelicobacter pylori. Helicobacter 2013, 19, 17-25. [CrossRef] [PubMed]

50. Kyrillos, A.; Arora, G.; Murray, B.; Rosenwald, A.G. The Presence of Phage Orthologous Genes inHelicobacter pyloriCorrelates with the Presence of the Virulence FactorsCagAandVacA. Helicobacter 2015, 21, 226-233. [CrossRef]

51. Ferreira, R.M.; Pinto-Ribeiro, I.; Wen, X.; Marcos-Pinto, R.; Dinis-Ribeiro, M.; Carneiro, F.; Figueiredo, C. Helicobacter pylori cagAPromoter Region Sequences Influence CagA Expression and Interleukin 8 Secretion. J. Infect. Dis. 2015, 213, 669-673. [CrossRef]

52. Eskandari-Nasab, E.; Sepanjnia, A.; Moghadampour, M.; Hadadi-Fishani, M.; Rezaeifar, A.; Asadi-Saghandi, A.; Sadeghi-Kalani, B.; Manshadi, M.D.; Pourrajab, F.; Pourmasoumi, H. Circulating levels of interleukin (IL)-12 and IL-13 in Helicobacter pyloriinfected patients, and their associations with bacterial CagA and VacA virulence factors. Scand. J. Infect. Dis. 2012, 45, 342-349. [CrossRef]

53. Bridge, D.R.; Blum, F.C.; Jang, S.; Kim, J.; Cha, J.-H.; Merrell, D.S. Creation and Initial Characterization of Isogenic Helicobacter pylori CagA EPIYA Variants Reveals Differential Activation of Host Cell Signaling Pathways. Sci. Rep. 2017, 7, 1-14. [CrossRef] [PubMed]

54. Júnior, M.F.; Batista, S.D.A.; Barbuto, R.C.; Gomes, A.D.; Queiroz, D.M.M.; Araújo, I.D.; Caliari, M.V. CagA-positive Helicobacter pylori strain containing three EPIYA $C$ phosphorylation sites produces increase of $G$ cell and decrease of D cell in experimentally infected gerbils (Meriones unguiculatus). Adv. Med. Sci. 2016, 61, 231-236. [CrossRef] [PubMed]

55. Lai, C.-H.; Chang, Y.-C.; Du, S.-Y.; Wang, H.-J.; Kuo, C.-H.; Fang, S.-H.; Fu, H.; Lin, H.; Chiang, A.; Wang, W. Cholesterol Depletion Reduces Helicobacter pylori CagA Translocation and CagA-Induced Responses in AGS Cells. Infect. Immun. 2008, 76, 3293-3303. [CrossRef] [PubMed]

56. Figura, N.; Trabalzini, L.; Mini, R.; Bernardini, G.; Scaloni, A.; Talamo, F.; Lusini, P.; Ferro, E.; Martelli, P.; Santucci, A. Inactivation of Helicobacter pylori cagA Gene Affects Motility. Helicobacter 2004, 9, 185-193. [CrossRef] [PubMed]

57. Baidya, A.K.; Bhattacharya, S.; Chowdhury, R. Role of the Flagellar Hook-Length Control Protein FliK and $\sigma 28$ incagAExpression in Gastric Cell-AdheredHelicobacter pylori. J. Infect. Dis. 2014, 211, 1779-1789. [CrossRef]

58. Bergé, C.; Terradot, L. Structural Insights into Helicobacter pylori Cag Protein Interactions with Host Cell Factors. In Current Topics in Microbiology and Immunology Molecular Pathogenesis and Signal Transduction by Helicobacter pylori; Springer: Cham, Switzerland, 2017; pp. 129-147.

59. Shibata, A.; Parsonnet, J.; Longacre, T.A.; Garcia, M.I.; Puligandla, B.; Davis, R.E.; Vogelman, J.H.; Orentreich, N.; Habel, L.A. CagA status of Helicobacter pylori infection and p53 gene mutation in gastric adenocarcinoma. Carcinogenesis 2002, 23, 419-424. [CrossRef] 
60. Mansour, K.B.; Fendri, C.; Zribi, M.; Masmoudi, A.; Labbene, M.; Fillali, A.; Mami, N.B.; Najjar, T.; Meherzi, A.; Sfar, T.; et al. Prevalence of Helicobacter pylori vacA, cagA, iceA and oipA genotypes in Tunisian patients. Ann. Clin. Microbiol. Antimicrob. 2010, 9, 10. [CrossRef]

61. Mohamed, R.; Hanafiah, A.; Rose, I.M.; Manaf, M.R.A.; Abdullah, S.A.; Sagap, I.; van Belkum, A.; Yaacob, J.A. Helicobacter pylori cagA gene variants in Malaysians of different ethnicity. Eur. J. Clin. Microbiol. Infect. Dis. 2009, 28, 865-869. [CrossRef]

62. Chomvarin, C.; Namwat, W.; Chaicumpar, K.; Mairiang, P.; Sangchan, A.; Sripa, B.; Tor-Udom, S.; Vilaichone, R. Prevalence of Helicobacter pylori vacA, cagA, cagE, iceA and babA2 genotypes in Thai dyspeptic patients. Int. J. Infect. Dis. 2008, 12, 30-36. [CrossRef]

63. Cavalcante, M.Q.D.F.; Silva, C.I.S.; Braga-Neto, M.B.; Fialho, A.B.C.; Fialho, A.N.; Barbosa, A.M.C.; Cruz, F.W.S.; Rocha, G.A.; Queiroz, D.M.M.d.; Braga, L.L.B.C. Helicobacter pylori vacA and cagA genotypes in patients from northeastern Brazil with upper gastrointestinal diseases. Memó. Inst. Oswaldo Cruz 2012, 107, 561-563. [CrossRef]

64. Faundez, G.; Troncoso, M.; Figueroa, G. cagA and vacA in strains of Helicobacter pylori from ulcer and non-ulcerative dyspepsia patients. BMC Gastroenterol. 2002, 2, 20. [CrossRef] [PubMed]

65. Karlsson, A.; Ryberg, A.; Dehnoei, M.; Borch, K.; Monstein, H.-J. Association between cagA and vacA genotypes and pathogenesis in a Helicobacter pylori infected population from South-eastern Sweden. BMC Microbiol. 2012, 12, 129. [CrossRef] [PubMed]

66. Sahara, S.; Sugimoto, M.; Vilaichone, R.-K.; Mahachai, V.; Miyajima, H.; Furuta, T.; Yamaoka, Y. Role of Helicobacter pylori cagA EPIYA motif and vacAgenotypes for the development of gastrointestinal diseases in Southeast Asian countries: A meta-analysis. BMC Infect. Dis. 2012, 12, 223. [CrossRef] [PubMed]

67. Ando, T.; Peek, R.M.; Pride, D.; Levine, S.M.; Takata, T.; Lee, Y.-C.; Kusugami, K.; van der Ende, A.; Kuipers, E.J.; Kusters, J.G.; et al. Polymorphisms of Helicobacter pylori HP0638 Reflect Geographic Origin and Correlate with cagA Status. J. Clin. Microbiol. 2002, 40, 239-246. [CrossRef]

68. Choi, S.I.; Yoon, C.; Park, M.R.; Lee, D.; Kook, M.-C.; Lin, J.-X.; Kang, J.H.; Ashktorab, H.; Smoot, D.T.; Yoon, S.S.; et al. CDX1 Expression Induced by CagA-Expressing Helicobacter pylori Promotes Gastric Tumorigenesis. Mol. Cancer Res. 2019, 17, $2169-2183$. [CrossRef]

69. Yu, H.; Zeng, J.; Liang, X.; Wang, W.; Zhou, Y.; Sun, Y.; Liu, S.; Li, W.; Chen, C.; Jia, J. Helicobacter pylori Promotes EpithelialMesenchymal Transition in Gastric Cancer by Downregulating Programmed Cell Death Protein 4 (PDCD4). PLoS ONE 2014 9, e105306. [CrossRef]

70. Lin, L.; Wei, H.; Yi, J.; Xie, B.; Chen, J.; Zhou, C.; Wang, L.; Yang, Y. Chronic CagA-positive Helicobacter pylori infection with MNNG stimulation synergistically induces mesenchymal and cancer stem cell-like properties in gastric mucosal epithelial cells. J. Cell. Biochem. 2019, 120, 17635-17649. [CrossRef]

71. Bessède, E.; Staedel, C.; Amador, L.A.A.; Nguyen, P.H.; Chambonnier, L.; Hatakeyama, M.; Belleannee, G.; Megraud, F.; Varon, C. Helicobacter pylori generates cells with cancer stem cell properties via epithelial-mesenchymal transition-like changes. Oncogene 2013, 33, 4123-4131. [CrossRef]

72. Lee, D.-G.; Kim, H.S.; Lee, Y.S.; Kim, S.; Cha, S.Y.; Ota, I.; Kim, N.H.; Cha, Y.H.; Yang, D.H.; Lee, Y.; et al. Helicobacter pylori CagA promotes Snail-mediated epithelial-mesenchymal transition by reducing GSK-3 activity. Nat. Commun. 2014, 5, 1-13. [CrossRef]

73. Krzysiek-Maczka, G.; Targosz, A.; Szczyrk, U.; Strzalka, M.; Brzozowski, T.; Ptak-Belowska, A. Involvement of epithelialmesenchymal transition-inducing transcription factors in the mechanism of Helicobacter pylori-induced fibroblasts activation. J. Physiol. Pharmacol. 2019, 70, 727-736.

74. Huang, L.; Wang, Z.Y.; Pan, D.D. Penicillin-binding protein 1A mutation-positive Helicobacter pylori promotes epithelialmesenchymal transition in gastric cancer via the suppression of microRNA-134. Int. J. Oncol. 2018, 54, 916-928. [CrossRef] [PubMed]

75. Marques, M.S.; Melo, J.; Cavadas, B.; Mendes, N.; Pereira, L.; Carneiro, F.; Figueiredo, C.; Leite, M. Afadin Downregulation by Helicobacter pylori Induces Epithelial to Mesenchymal Transition in Gastric Cells. Front. Microbiol. 2018, 9, 2712. [CrossRef] [PubMed]

76. Li, N.; Feng, Y.; Hu, Y.; He, C.; Xie, C.; Ouyang, Y.; Artim, S.C.; Huang, D.; Zhu, Y.; Luo, Z. Helicobacter pylori CagA promotes epithelial mesenchymal transition in gastric carcinogenesis via triggering oncogenic YAP pathway. J. Exp. Clin. Cancer Res. 2018, 37, 1-15. [CrossRef] [PubMed]

77. Lang, B.J.; Gorrell, R.J.; Tafreshi, M.; Hatakeyama, M.; Kwok, T.; Price, J.T. The Helicobacter pylori cytotoxin CagA is essential for suppressing host heat shock protein expression. Cell Stress Chaperones 2016, 21, 523-533. [CrossRef] [PubMed]

78. Inagaki, T.; Nishiumi, S.; Ito, Y.; Yamakawa, A.; Yamazaki, Y.; Yoshida, M.; Azuma, T. Associations between cagA, vacA, and the clinical outcimes of Helicobacter pylori infections in Okinawa, Japan. Kobe. J. Med. Sci. 2017, 63, E58-E67.

79. Kaklikkaya, N.; Cubukcu, K.; Aydin, F.; Bakir, T.; Erkul, S.; Tosun, I.; Topbas, M.; Yazici, Y.; Buruk, C.K.; Erturk, M. Significance of cagA status and vacA subtypes of Helicobacter pylori in determining gastric histopathology: Virulence markers of $\mathrm{H}$. pylori and histopathology. J. Gastroenterol. Hepatol. 2006, 21, 1042-1047. [CrossRef]

80. Zambon, C.-F. Helicobacter pylori babA2, cagA, and s1 vacA genes work synergistically in causing intestinal metaplasia. J. Clin. Pathol. 2003, 56, 287-291. [CrossRef] [PubMed]

81. Wang, D.; Li, Q.; Gong, Y.; Yuan, Y. The association between vacA or cagA status and eradication outcome of Helicobacter pylori infection: A meta-analysis. PLoS ONE 2017, 12, e0177455. [CrossRef] [PubMed] 
82. Raju, D.; Hussey, S.; Ang, M.; Terebiznik, M.R.; Sibony, M.; Galindo-Mata, E.; Gupta, V.; Blanke, S.R.; Delgado, A.; Romero-Gallo, J.; et al. Vacuolating cytotoxin and variants in Atg16L1 that disrupt autophagy promote Helicobacter pylori infection in humans. Gastroenterology 2012, 142, 1160-1171. [CrossRef]

83. Wada, A. Helicobacter pylori Vacuolating Cytotoxin, VacA, Is Responsible for Gastric Ulceration. J. Biochem. 2004, 136, 741-746. [CrossRef]

84. Mcclain, M.; Beckett, A.; Cover, T. Helicobacter pylori Vacuolating Toxin and Gastric Cancer. Toxins 2017, 9, 316. [CrossRef] [PubMed]

85. Keikha, M.; Ali-Hassanzadeh, M.; Karbalaei, M. Association of Helicobacter pylori vacAgenotypes and peptic ulcer in Iranian population: A systematic review and meta-analysis. BMC Gastroenterol. 2020, 20, 266. [CrossRef] [PubMed]

86. Atrisco-Morales, J.; Martínez-Santos, V.I.; Román-Román, A.; Alarcón-Millán, J.; De Sampedro-Reyes, J.; Cruz-Del Carmen, I.; Martínez-Carrillo, D.N.; Fernández-Tilapa, G. vacA s1m1 genotype and cagA EPIYA-ABC pattern are predominant among Helicobacter pylori strains isolated from Mexican patients with chronic gastritis. J. Med. Microbiol. 2010, 67, 314-324. [CrossRef] [PubMed]

87. Román-Román, A.; Martínez-Carrillo, D.N.; Atrisco-Morales, J.; Azúcar-Heziquio, J.C.; Cuevas-Caballero, A.S.; Castañón-Sánchez, C.A.; Reyes-Ríos, R.; Betancourt-Linares, R.; Reyes-Navarrete, S.; Cruz-Del Carmen, I.; et al. Helicobacter pylori vacA s1m1genotype but not cagA or babA2 increase the risk of ulcer and gastric cancer in patients from Southern Mexico. Gut Pathog. 2017, 13, 18. [CrossRef] [PubMed]

88. Ricci, V. Relationship between VacA Toxin and Host Cell Autophagy in Helicobacter pylori Infection of the Human Stomach: A Few Answers, Many Questions. Toxins. 2016, 8, 203. [CrossRef] [PubMed]

89. Chauhan, N.; Tay, A.C.Y.; Marshall, B.J.; Jain, U. Helicobacter pylori VacA, a distinct toxin exerts diverse functionalities in numerous cells: An overview. Helicobacter 2018, 24, e12544. [CrossRef] [PubMed]

90. Link, A.; Langner, C.; Schirrmeister, W.; Habendorf, W.; Weigt, J.; Venerito, M.; Tammer, I.; Schluter, D.; Schlaermann, P.; Meyer, T.F.; et al. Helicobacter pylori vacA genotype is a predominant determinant of immune response to Helicobacter pylori CagA. World J. Gastroenterol. 2017, 23, 4712-4723. [CrossRef] [PubMed]

91. Djekic, A.; Müller, A. The Immunomodulator VacA Promotes Immune Tolerance and Persistent Helicobacter pylori Infection through Its Activities on T-Cells and Antigen-Presenting Cells. Toxins 2016, 8, 187. [CrossRef] [PubMed]

92. Necchi, V.; Sommi, P.; Vanoli, A.; Fiocca, R.; Ricci, V.; Solcia, E. Natural history of Helicobacter pylori VacA toxin in human gastric epithelium in vivo: Vacuoles and beyond. Sci. Rep. 2017, 7, 14526. [CrossRef] [PubMed]

93. Abdullah, M.; Greenfield, L.K.; Bronte-Tinkew, D.; Capurro, M.I.; Rizzuti, D.; Jones, N.L. VacA promotes CagA accumulation in gastric epithelial cells during Helicobacter pylori infection. Sci. Rep. 2019, 9, 38. [CrossRef] [PubMed]

94. Bridge, D.R.; Merrell, D.S. Polymorphism in the Helicobacter pylori CagA and VacA toxins and disease. Gut Microb. 2013, 4, 101-117. [CrossRef] [PubMed]

95. Foegeding, N.J.; Raghunathan, K.; Campbell, A.M.; Kim, S.W.; Lau, K.S.; Kenworthy, A.K.; Cover, T.L.; Ohi, M.D. Intracellular Degradation of Helicobacter pylori VacA Toxin as a Determinant of Gastric Epithelial Cell Viability. Infect. Immun. 2019, 87, e00783-18. [CrossRef] [PubMed]

96. Basiri, Z.; Safaralizadeh, R.; Bonyadi, M.J.; Somi, M.H.; Mahdavi, M.; Latifi-Navid, S. Helicobacter pylori vacA d1 Genotype Predicts Risk of Gastric Adenocarcinoma and Peptic Ulcers in Northwestern Iran. Asian Pac. J. Cancer Prev. 2014, 15, 1575-1579. [CrossRef] [PubMed]

97. Ahmad, T.; Sohail, K.; Rizwan, M.; Mukhtar, M.; Bilal, R.; Khanum, A. Prevalence ofHelicobacter pyloripathogenicityassociatedcagAandvacAgenotypes among Pakistani dyspeptic patients. FEMS Immunol. Med. Microbiol. 2009, 55, 34-38. [CrossRef] [PubMed]

98. Bakhti, S.Z.; Latifi-Navid, S.; Mohammadi, S.; Zahri, S.; Bakhti, F.S.; Feizi, F.; Yazdanbod, A.; Siavoshi, F. Relevance ofHelicobacter pylori vacA 3'-end Region Polymorphism to Gastric Cancer. Helicobacter 2015, 21, 305-316. [CrossRef] [PubMed]

99. Sheikh, A.F.; Yadyad, M.J.; Goodarzi, H.; Hashemi, S.J.; Aslani, S.; Assarzadegan, M.-A.; Ranjbar, R. CagA and vacA allelic combination of Helicobacter pylori in gastroduodenal disorders. Microb. Pathogen. 2018, 122, 144-150. [CrossRef] [PubMed]

100. Sugimoto, M.; Yamaoka, Y. The association of vacA genotype and Helicobacter pylori-related disease in Latin American and African populations. Clin. Microbiol. Infect. 2009, 15, 835-842. [CrossRef]

101. Mottaghi, B.; Safaralizadeh, R.; Bonyadi, M.; Latifi-Navid, S.; Somi, M.H. Helicobacter pylori vacA i region polymorphism but not babA2 status associated to gastric cancer risk in northwestern Iran. Clin. Exp. Med. 2014, 16, 57-63. [CrossRef] [PubMed]

102. Bachir, M.; Allem, R.; Tifrit, A.; Medjekane, M.; Drici, A.E.-M.; Diaf, M.; Douidi, K.T. Primary antibiotic resistance and its relationship with cagA and vacA genes in Helicobacter pylori isolates from Algerian patients. Braz. J. Microbiol. 2018, 49, 544-551. [CrossRef]

103. Ferreira, R.M.; Machado, J.C.; Figueiredo, C. Clinical relevance of Helicobacter pylori vacA and cagA genotypes in gastric carcinoma. Best Pract. Res.Clin. Gastroenterol. 2014, 28, 1003-1015. [CrossRef]

104. Trang, T.T.H.; Binh, T.T.; Yamaoka, Y. Relationship between vacA Types and Development of Gastroduodenal Diseases. Toxins 2016, 8, 182. [CrossRef] [PubMed]

105. Rahimian, G.; Sanei, M.H.; Shirzad, H.; Azadegan-Dehkordi, F.; Taghikhani, A.; Salimzadeh, L.; Hashemzadeh-Chaleshtori, M.; Rafieian-Kopaei, M.; Bagheri, N. Virulence factors of Helicobacter pylori vacA increase markedly gastric mucosal TGF- $\beta 1$ mRNA expression in gastritis patients. Microb. Pathog. 2014, 67, 1-7. [CrossRef] [PubMed] 
106. Figura, N.; Valassina, M.; Moretti, E.; Vindigni, C.; Collodel, G.; Iacoponi, F.; Giordano, N.; Roviello, F.; Marrelli, D. Histological variety of gastric carcinoma and Helicobacter pylori cagA and vacA polymorphism. Eur. J. Gastroenterol. Hepatol. 2015, 27, 1017-1021. [CrossRef] [PubMed]

107. Capurro, M.I.; Greenfield, L.K.; Prashar, A.; Xia, S.; Abdullah, M.; Wong, H.; Zhong, X.Z.; Bertaux-Skeirik, N.; Chakrabarti, J.; Siddiqui, I.; et al. VacA generates a protective intracellular reservoir for Helicobacter pylori that is eliminated by activation of the lysosomal calcium channel TRPML1. Nat. Microbiol. 2019, 4, 1411-1423. [CrossRef] [PubMed]

108. Harris, A.G.; Hazell, S.L. Localisation ofHelicobacter pyloricatalase in both the periplasm and cytoplasm, and its dependence on the twin-arginine target protein, KapA, for activity. FEMS Microbiol. Lett. 2003, 229, 283-289. [CrossRef]

109. Mahawar, M.; Tran, V.; Sharp, J.S.; Maier, R.J. Synergistic roles of Helicobacter pylori methionine sulfoxide reductase and GroEL in repairing oxidant-damaged catalase. J. Biol. Chem. 2011, 286, 19159-19169. [CrossRef] [PubMed]

110. Boonjakuakul, J.K.; Syvanen, M.; Suryaprasad, A.; Bowlus, C.L.; Solnick, J.V. Transcription profile of Helicobacter pylori in the human stomach reflects its physiology in vivo. J. Infect. Dis. 2004, 190, 946-956. [CrossRef]

111. Switala, J.; Loewen, P.C. Diversity of properties among catalases. Arch. Biochem. Biophys. 2002, 401, 145-154. [CrossRef]

112. Benoit, S.L.; Maier, R.J. Helicobacter Catalase Devoid of Catalytic Activity Protects the Bacterium against Oxidative Stress. J. Biol. Chem. 2016, 291, 23366-23373. [CrossRef]

113. Richter, C.; Mukherjee, O.; Ermert, D.; Singh, B.; Su, Y.-C.; Agarwal, V.; Blom, A.M.; Riesbeck, K. Moonlighting of Helicobacter pylori catalase protects against complement-mediated killing by utilising the host molecule vitronectin. Sci. Rep. 2016, 6, 24391. [CrossRef]

114. Ramarao, N.; Gray-Owen, S.D.; Meyer, T.F. Helicobacter pylori induces but survives the extracellular release of oxygen radicals from professional phagocytes using its catalase activity. Mol. Microbiol. 2000, 38, 103. [CrossRef] [PubMed]

115. Basu, M.; Czinn, S.J.; Blanchard, T.G. Absence of Catalase Reduces Long-Term Survival of Helicobacter pylori in Macrophage Phagosomes. Helicobacter 2004, 9, 211-216. [CrossRef] [PubMed]

116. Harris, A.G.; Wilson, J.E.; Danon, S.J.; Dixon, M.F.; Donegan, K.; Hazell, S.L. Catalase (KatA) and KatA-associated protein (KapA) are essential to persistent colonization in the Helicobacter pylori SS1 mouse model. Microbiology 2003, 149, 665-672. [CrossRef] [PubMed]

117. Hazell, S.L.; Graham, D.Y. Unsaturated fatty acids and viability of Helicobacter (Campylobacter) pylori. J. Clin. Microbiol. 1990, 28, 1060-1061. [CrossRef] [PubMed]

118. Mori, M.; Suzuki, H.; Suzuki, M.; Kai, A.; Miura, S.; Ishii, H. Catalase and Superoxide Dismutase Secreted fromHelicobacter pylori. Helicobacter 1997, 2, 100-105. [CrossRef] [PubMed]

119. Guy, B.; Krell, T.; Sanchez, V.; Kennel, A.; Manin, C.; Sodoyer, R. Do Th1 or Th2 sequence motifs exist in proteins? Immunol. Lett. 2005, 96, 261-275. [CrossRef]

120. Harris, A.G.; Hinds, F.E.; Beckhouse, A.G.; Kolesnikow, T.; Hazell, S.L. Resistance to hydrogen peroxide in Helicobacter pylori: Role of catalase (KatA) and Fur, and functional analysis of a novel gene product designated 'KatA-associated protein', KapA (HP0874). Microbiology 2002, 148, 3813-3825. [CrossRef]

121. Miyashita, M.; Joh, T.; Watanabe, K.; Todoroki, I.; Seno, K.; Ohara, H.; Nomura, T.; Miyata, M.; Kasugai, K.; Tochikubo, K.; et al. Immune responses in mice to intranasal and intracutaneous administration of a DNA vaccine encoding Helicobacter pylori-catalase. Vaccine 2002, 20, 2336-2342. [CrossRef]

122. Švagelj, D.; Terzić, V.; Dovhanj, J.; Švagelj, M.; Cvrković, M.; Švagelj, I. Superoxide dismutases in chronic gastritis. Apmis 2016, 124, 252-256. [CrossRef]

123. Smoot, D.T.; Elliott, T.B.; Verspaget, H.W.; Jones, D.; Allen, C.R.; Vernon, K.G.; Bremner, T.; Kidd, I.R.; Kim, K.S.; Groupman, J.D. Influence of Helicobacter pylori on reactive oxygen-induced gastric epithelial cell injury. Carcinogenesis 2000, 21, $2091-2095$. [CrossRef]

124. Bauer, G.; Bereswill, S.; Aichele, P.; Glocker, E. Helicobacter pylori protects oncogenically transformed cells from reactive oxygen species-mediated intercellular induction of apoptosis. Carcinogenesis 2014, 35, 1582-1591. [CrossRef] [PubMed]

125. Negovan, A.; Iancu, M.; Tripon, F.; Crauciuc, A.; Mocan, S.; Bănescu, C. The CAT-262 C>T, MnSOD Ala16Val, GPX1 Pro198Leu Polymorphisms Related to Oxidative Stress and the Presence of Gastric Lesions. J. Gastrointest. Liver Dis. 2018, 27, 371-378. [CrossRef] [PubMed]

126. Stent, A.; Every, A.L.; Chionh, Y.T.; Ng, G.Z.; Sutton, P. Superoxide dismutase from Helicobacter pylori suppresses the production of pro-inflammatory cytokines during in vivo infection. Helicobacter 2017, 23. [CrossRef] [PubMed]

127. Noguchi, K.; Kato, K.; Moriya, T.; Suzuki, T.; Saito, M.; Kikuchi, T.; Yang, J.; Imatani, A.; Sekine, H.; Ohara, S.; et al. Analysis of cell damage in Helicobacter pylori-associated gastritis. Pathol. Int. 2002, 52, 110-118. [CrossRef] [PubMed]

128. Seyler, R.W.; Olson, J.W.; Maier, R.J. Superoxide Dismutase-Deficient Mutants ofHelicobacter pylori Are Hypersensitive to Oxidative Stress and Defective in Host Colonization. Infect. Immun. 2001, 69, 4034-4040. [CrossRef] [PubMed]

129. Morishita, K.; Takeuchi, H.; Morimoto, N.; Shimamura, T.; Kadota, Y.; Tsuda, M.; Taniguchi, T.; Ukeda, H.; Yamamoto, T.; Sugiura, T. Superoxide dismutase activity of Helicobacter pylori per se from 158 clinical isolates and the characteristics. Microbiol. Immunol. 2012, 56, 262-272. [CrossRef]

130. Lee, H.S.; Choe, G.; Kim, W.H.; Kim, H.H.; Song, J.; Park, K.U. Expression of Lewis antigens and their precursors in gastric mucosa: Relationship with Helicobacter pylori infection and gastric carcinogenesis. J. Pathol. 2006, 209, 88-94. [CrossRef] 
131. Wang, G.; Ge, Z.; Rasko, D.A.; Taylor, D.E. Lewis antigens in Helicobacter pylori: Biosynthesis and phase variation. Mol. Microbiol. 2002, 36, 1187-1196. [CrossRef]

132. Lozniewski, A.; Haristoy, X.; Rasko, D.A.; Hatier, R.; Plenat, F.; Taylor, D.E.; Angioi-Duprez, K. Influence of Lewis Antigen Expression by Helicobacter pylori on Bacterial Internalization by Gastric Epithelial Cells. Infect. Immun. 2003, 71, $2902-2906$. [CrossRef]

133. Moran, A.P. Relevance of fucosylation and Lewis antigen expression in the bacterial gastroduodenal pathogen Helicobacter pylori. Carbohydr. Res. 2008, 343, 1952-1965. [CrossRef]

134. Pohl, M.A.; Zhang, W.; Shah, S.N.; Sanabria-Valentín, E.L.; Perez-Perez, G.I.; Blaser, M.J. Genotypic and Phenotypic Variation of Lewis Antigen Expression in Geographically Diverse Helicobacter pylori Isolates. Helicobacter 2011, 16, 475-481. [CrossRef] [PubMed]

135. Boren, T.; Falk, P.; Roth, K.A.; Larson, G.; Normark, S. Attachment of Helicobacter pylori to human gastric epithelium mediated by blood group antigens. Science 1993, 262, 1892-1895. [CrossRef] [PubMed]

136. Teixeira, A.; David, L.; Reis, C.A.; Costa, J.; Sobrinho-Simões, M. Expression of mucins (MUC1, MUC2, MUC5AC, and MUC6) and type 1 Lewis antigens in cases with and withoutHelicobacter pyloricolonization in metaplastic glands of the human stomach. J. Pathol. 2002, 197, 37-43. [CrossRef] [PubMed]

137. Yang, Y.-J.; Wu, J.-J.; Sheu, B.-S.; Chen, C.-R.; Lu, C.-C.; Yang, H.-B. Helicobacter pylori infection can change the intensity of gastric Lewis antigen expressions differently between adults and children. J. Biomed. Sci. 2007, 15, 29-36. [CrossRef] [PubMed]

138. Nogueira, A.M.; Marques, T.; Soares, P.C.M.; David, L.; Reis, C.A.; Serpa, J. Lewis Antigen Expression in Gastric Mucosa of Children: Relationship With Helicobacter pylori Infection. J. Pediatr. Gastroenterol. Nutr. 2004, 38, 85-91. [CrossRef] [PubMed]

139. Rasko, D.A.; Keelan, M.; Thomson, A.B.; Taylor, D.E. Lewis antigen phenotype is altered in Helicobacter pylori isolated from asymptomatic subjects. Gastroenterology 2000, 118. [CrossRef]

140. Martins, L.C. ABH and Lewis antigen distributions in blood, saliva and gastric mucosa and $\mathrm{H}$ pylori infection in gastric ulcer patients. World J. Gastroenterol. 2006, 12, 1120. [CrossRef]

141. Heneghan, M.A.; McCarthy, C.F.; Janulaityte, D.; Moran, A.P. Relationship of Anti-Lewis x and Anti-Lewis y Antibodies in Serum Samples from Gastric Cancer and Chronic Gastritis Patients to Helicobacter pylori-Mediated Autoimmunity. Infect. Immun. 2001, 69, 4774-4781. [CrossRef]

142. Sheu, S.M.; Sheu, B.S.; Yang, H.B.; Lei, H.Y.; Wu, J.J. Anti-Lewis X Antibody Promotes Helicobacter pylori Adhesion to Gastric Epithelial Cells. Infect. Immun. 2007, 75, 2661-2667. [CrossRef]

143. Hynes, S.O.; Keenan, J.I.; Ferris, J.A.; Annuk, H.; Moran, A.P. Lewis Epitopes on Outer Membrane Vesicles of Relevance to Helicobacter pylori Pathogenesis. Helicobacter 2005, 10, 146-156. [CrossRef]

144. Chmiela, M.; Wadstrom, T.; Folkesson, H.; Małecka, I.P.; Czkwianianc, E.; Rechciński, T.; Rudnicka, W. Anti-Lewis X antibody and Lewis X-anti-Lewis X immune complexes in Helicobacter pylori infection. Immunol. Lett. 1998, 61, 119-125. [CrossRef]

145. Mendz, G.L.; Hazell, S.L. The urea cycle of Helicobacter pylori. Microbiology 1996, 142, 2959-2967. [CrossRef] [PubMed]

146. McGee, D.J.; Zabaleta, J.; Viator, R.J.; Testerman, T.L.; Ochoa, A.C.; Mendz, G.L. Purification and characterization of Helicobacter pylori arginase, RocF: Unique features among the arginase superfamily. Eur. J. Biochem. 2004, 271, 1952-1962. [CrossRef] [PubMed]

147. Zhang, J.; Zhang, X.; Wu, C.; Lu, D.; Guo, G.; Mao, X.; Zhang, Y.; Wang, D.C.; Li, D.; Zou, Q. Expression, purification and characterization of arginase from Helicobacter pylori in its apo form. PLoS ONE 2011, 6, e26205. [CrossRef] [PubMed]

148. Zhang, X.; Zhang, J.; Zhang, R.; Guo, Y.; Wu, C.; Mao, X.; Guo, G.; Zhang, Y.; Li, D.; Zou, Q. Structural, enzymatic and biochemical studies on Helicobacter pylori arginase. Int. J. Biochem Cell Biol. 2013, 45, 995-1002. [CrossRef] [PubMed]

149. Zabaleta, J.; McGee, D.J.; Zea, A.H.; Hernández, C.P.; Rodriguez, P.C.; Sierra, R.A.; Correa, P.; Ochoa, A.C. Helicobacter pylori arginase inhibits T cell proliferation and reduces the expression of the TCR zeta-chain (CD3zeta). J. Immunol. 2004, 173, 586-593. [CrossRef]

150. Gobert, A.P.; McGee, D.J.; Akhtar, M.; Mendz, G.L.; Newton, J.C.; Cheng, Y.; Mobley, H.L.; Wilson, K.T. Helicobacter pylori arginase inhibits nitric oxide production by eukaryotic cells: A strategy for bacterial survival. Proc. Natl. Acad. Sci. USA 2001, 98, 13844-13849. [CrossRef]

151. Lewis, N.D.; Asim, M.; Barry, D.P.; Singh, K.; de Sablet, T.; Boucher, J.L.; Gobert, A.P.; Chaturvedi, R.; Wilson, K.T. Arginase II restricts host defense to Helicobacter pylori by attenuating inducible nitric oxide synthase translation in macrophages. J. Immunol. 2010, 184, 2572-2582. [CrossRef]

152. Hardbower, D.M.; Asim, M.; Murray-Stewart, T.; Casero RAJr Verriere, T.; Lewis, N.D.; Chaturvedi, R.; Piazuelo, M.B.; Wilson, K.T. Arginase 2 deletion leads to enhanced M1 macrophage activation and upregulated polyamine metabolism in response to Helicobacter pylori infection. Amino Acids 2016, 48, 2375-2388. [CrossRef]

153. Kim, S.H.; Sierra, R.A.; McGee, D.J.; Zabaleta, J. Transcriptional profiling of gastric epithelial cells infected with wild type or arginase-deficient Helicobacter pylori. BMC Microbiol. 2012, 12, 175. [CrossRef]

154. Gobert, A.P.; Cheng, Y.; Wang, J.Y.; Boucher, J.L.; Iyer, R.K.; Cederbaum, S.D.; Casero, R.A., Jr.; Newton, J.C.; Wilson, K.T. Helicobacter pylori induces macrophage apoptosis by activation of arginase II. J. Immunol. 2002, 168, 4692-4700. [CrossRef] [PubMed]

155. Berstad, A.E.; Berstad, K.; Berstad, A. PH-activated phospholipase A2: An important mucosal barrier breaker in peptic ulcer disease. Scand. J. Gastroenterol. 2002, 37, 738-742. [CrossRef] [PubMed] 
156. Lusini, P.; Figura, N.; Valassina, M.; Roviello, F.; Vindigni, C.; Trabalzini, L.; Nuti, R.; Lenzi, C.; Gonnelli, C.; Nardi, M.; et al. Increased phospholipase activity in Helicobacter pylori strains isolated from patients with gastric carcinoma. Dig. Liver Dis. 2005, 37, 232-239. [CrossRef] [PubMed]

157. Sitaraman, R.; Israel, D.A.; Romero-Gallo, J.; Peek, R.M., Jr. Cell-associated hemolysis induced by Helicobacter pylori is mediated by phospholipases with mitogen-activated protein kinase-activating properties. J. Clin. Microbiol. 2012, 50, 1014-1018. [CrossRef]

158. Stein, S.C.; Faber, E.; Bats, S.H.; Murillo, T.; Speidel, Y.; Coombs, N.; Josenhans, C. Helicobacter pylori modulates host cell responses by CagT4SS-dependent translocation of an intermediate metabolite of LPS inner core heptose biosynthesis. PLoS Pathog. 2017, 13, e1006514. [CrossRef]

159. Hildebrandt, E.; Mcgee, D.J. Helicobacter pylori lipopolysaccharide modification, Lewis antigen expression, and gastric colonization are cholesterol-dependent. BMC Microbiol. 2009, 9, 258. [CrossRef] [PubMed]

160. Eaton, K.A.; Logan, S.M.; Baker, P.E.; Peterson, R.A.; Monteiro, M.A.; Altman, E. Helicobacter pylori with a Truncated Lipopolysaccharide O Chain Fails To Induce Gastritis in SCID Mice Injected with Splenocytes from Wild-Type C57BL/6J Mice. Infect. Immun. 2004, 72, 3925-3931. [CrossRef]

161. Chmiela, M. Structural modifications of Helicobacter pyloril ipopolysaccharide: An idea for how to live in peace. World J. Gastroenterol. 2014, 20, 9882. [CrossRef] [PubMed]

162. Gonciarz, W.; Krupa, A.; Hinc, K.; Obuchowski, M.; Moran, A.P.; Gajewski, A.; Chmiela, M. The effect of Helicobacter pylori infection and different $\mathrm{H}$. pylori components on the proliferation and apoptosis of gastric epithelial cells and fibroblasts. PLoS ONE 2019, 14, e0220636. [CrossRef] [PubMed]

163. Moran, A.P.; Knirel, Y.A.; Senchenkova, S.N.; Widmalm, G.; Hynes, S.O.; Jansson, P.-E. Phenotypic Variation in Molecular Mimicry betweenHelicobacter pyloriLipopolysaccharides and Human Gastric Epithelial Cell Surface Glycoforms. J. Biol. Chem. 2001, 277, 5785-5795. [CrossRef] [PubMed]

164. Li, H.; Liao, T.; Debowski, A.W.; Tang, H.; Nilsson, H.-O.; Stubbs, K.A.; Marshall, B.J.; Benghezal, M. Lipopolysaccharide Structure and Biosynthesis in Helicobacter pylori. Helicobacter 2016, 21, 445-461. [CrossRef] [PubMed]

165. Keenan, J.I.; Davis, K.A.; Beaugie, C.R.; Mcgovern, J.J.; Moran, A.P. Alterations inHelicobacter pyloriouter membrane and outer membrane vesicle-associated lipopolysaccharides under iron-limiting growth conditions*. Innate Immun. 2008, 14, 279-290. [CrossRef] [PubMed]

166. Pfannkuch, L.; Hurwitz, R.; Traulsen, J.; Sigulla, J.; Poeschke, M.; Matzner, L.; Kosma, P.; Schmid, M.; Meyer, T.F. ADP heptose, a novel pathogen-associated molecular pattern identified in Helicobacter pylori. FASEB J. 2019, 33, 9087-9099. [CrossRef] [PubMed]

167. Zimmermann, S.; Pfannkuch, L.; Al-Zeer, M.A.; Bartfeld, S.; Koch, M.; Liu, J.; Rechner, C.; Soerensen, M.; Sokolova, O.; Zamyatina, A.; et al. ALPK1- and TIFA-Dependent Innate Immune Response Triggered by the Helicobacter pylori Type IV Secretion System. Cell Rep. 2017, 20, 2384-2395. [CrossRef] [PubMed]

168. Gall, A.; Gaudet, R.G.; Gray Owen, S.D.; Salama, N.R. TIFA Signaling in Gastric Epithelial Cells Initiates the cag Type 4 Secretion System-Dependent Innate Immune Response to Helicobacter pylori Infection. mBio 2017, 8. [CrossRef] [PubMed]

169. Li, H.; Tang, H.; Debowski, A.; Stubbs, K.; Marshall, B.; Benghezal, M. Lipopolysaccharide Structural Differences between Western and Asian Helicobacter pylori Strains. Toxins 2018, 10, 364. [CrossRef] [PubMed]

170. Yokota, S.-I.; Amano, K.-I.; Nishitani, C.; Ariki, S.; Kuroki, Y.; Fujii, N. Implication of Antigenic Conversion of Helicobacter pylori Lipopolysaccharides That Involve Interaction with Surfactant Protein, D. Infect. Immun. 2012, 80, 2956-2962. [CrossRef]

171. Lepper, P.M.; Triantafilou, M.; Schumann, C.; Schneider, E.M.; Triantafilou, K. Lipopolysaccharides from Helicobacter pylori can act as antagonists for Toll-like receptor 4. Cellular Microbiol. 2005, 7, 519-528. [CrossRef]

172. Chavarría-Velázquez, C.O.; Torres-Martínez, A.C.; Montaño, L.F.; Rendón-Huerta, E.P. TLR2 activation induced by H. pylori LPS promotes the differential expression of claudin $-4,-6,-7$ and -9 via either STAT3 and ERK1/2 in AGS cells. Immunobiology 2018, 223, 38-48. [CrossRef]

173. Melit, L.E.; Mărginean, C.O.; Mărginean, C.D.; Mărginean, M.O. The Relationship between Toll-like Receptors andHelicobacter pylori-Related Gastropathies: Still a Controversial Topic. J. Immunol. Res. 2019, 1-10. [CrossRef]

174. Chochi, K.; Ichikura, T.; Kinoshita, M.; Majima, T.; Shinomiya, N.; Tsujimoto, H.; Kawabata, T.; Sugasawa, H.; Ono, S.; Seki, S.; et al. Helicobacter pylori Augments Growth of Gastric Cancers via the Lipopolysaccharide-Toll-like Receptor 4 Pathway whereas Its Lipopolysaccharide Attenuates Antitumor Activities of Human Mononuclear Cells. Clin. Cancer Res. 2008, 14, $2909-2917$. [CrossRef] [PubMed]

175. Kawahara, T.; Teshima, S.; Oka, A.; Sugiyama, T.; Kishi, K.; Rokutan, K. Type I Helicobacter pylori Lipopolysaccharide Stimulates Toll-Like Receptor 4 and Activates Mitogen Oxidase 1 in Gastric Pit Cells. Infect. Immun. 2001, 69, 4382-4389. [CrossRef] [PubMed]

176. Li, H.; Xia, J.-Q.; Zhu, F.-S.; Xi, Z.; Pan, C.; Gu, L.; Tian, Y. LPS promotes the expression of PD-L1 in gastric cancer cells through NF-kB activation. J. Cell Biochem. 2018, 119, 1-8. [CrossRef] [PubMed]

177. Semeraro, N.; Montemurro, P.; Piccoli, C.; Muoio, V.; Colucci, M.; Giuliani, G.; Fumarola, D.; Pece, S.; Moran, A.P. Effect of Helicobacter pylori Lipopolysaccharide (LPS) and LPS Derivatives on the Production of Tissue Factor and Plasminogen Activator Inhibitor Type 2 by Human Blood Mononuclear Cells. J. Infect. Dis. 1996, 174, 1255-1260. [CrossRef] [PubMed] 
178. Yokota, S.-I.; Okabayashi, T.; Rehli, M.; Fujii, N.; Amano, K.-I. Helicobacter pylori Lipopolysaccharides Upregulate Toll-Like Receptor 4 Expression and Proliferation of Gastric Epithelial Cells via the MEK1/2-ERK1/2 Mitogen-Activated Protein Kinase Pathway. Infect. Immun. 2009, 78, 468-476. [CrossRef] [PubMed]

179. Li, N.; Xu, H.; Ou, Y.; Feng, Z.; Zhang, Q.; Zhu, Q.; Cai, Z. LPS-induced CXCR7 expression promotes gastric Cancer proliferation and migration via the TLR4/MD-2 pathway. Diagn. Pathol. 2019, 14. [CrossRef]

180. Slomiany, B.L.; Slomiany, A. Helicobacter pylori LPS-induced gastric mucosal spleen tyrosine kinase (Syk) recruitment to TLR4 and activation occurs with the involvement of protein kinase C $\delta$. Inflammopharmacology 2018, 26, 805-815. [CrossRef]

181. Slomiany, B.L.; Slomiany, A. Role of LPS-elicited signaling in triggering gastric mucosal inflammatory responses to H. pylori: Modulatory effect of ghrelin. Inflammopharmacology 2017, 25, 415-429. [CrossRef]

182. Hansen, P.S.; Petersen, S.B.; Varming, K.; Nielsen, H. Helicobacter pylori Additive Effects of Helicobacter pylori Lipopolysaccharide and Proteins in Monocyte Inflammatory Responses. Scand. J. Gastroenterol. 2002, 37, 765-771. [CrossRef]

183. Xu, L.; Gong, C.; Li, G.; Wei, J.; Wang, T.; Meng, W.; Shi, M.; Wang, Y. Ebselen suppresses inflammation induced by Helicobacter pylori lipopolysaccharide via the p38 mitogen-activated protein kinase signaling pathway. Mol. Med. Rep. $2018,5,6847-6851$.

184. Basak, C.; Pathak, S.K.; Bhattacharyya, A.; Mandal, D.; Pathak, S.; Kundu, M. NF-kB- and C/EBP $\beta$-driven Interleukin-1 $\beta$ Gene Expression and PAK1-mediated Caspase-1 Activation Play Essential Roles in Interleukin-1 $\beta$ Release fromHelicobacter pyloriLipopolysaccharide-stimulated Macrophages. J. Biol. Chem. 2004, 280, 4279-4288. [CrossRef] [PubMed]

185. Taylor, J.M.; Ziman, M.E.; Huff, J.L.; Moroski, N.M.; Vajdy, M.; Solnick, J.V. Helicobacter pylori lipopolysaccharide promotes a Th1 type immune response in immunized mice. Vaccine 2006, 24, 4987-4994. [CrossRef] [PubMed]

186. Shimoyama, A.; Saeki, A.; Tanimura, N.; Tsutsui, H.; Miyake, K.; Suda, Y.; Fujimoto, Y.; Fukase, K. Chemical Synthesis of Helicobacter pylori Lipopolysaccharide Partial Structures and their Selective Proinflammatory Responses. Chem. Eur. J. 2011, 17, 14464-14474. [CrossRef] [PubMed]

187. Bliss, C.M.; Golenbock, D.T.; Keates, S.; Linevsky, J.K.; Kelly, C.P. Helicobacter pylori Lipopolysaccharide Binds to CD14 and Stimulates Release of Interleukin-8, Epithelial Neutrophil-Activating Peptide 78, and Monocyte Chemotactic Protein 1 by Human Monocytes. Infect. Immun. 1998, 66, 5357-5363. [CrossRef] [PubMed]

188. Pan, X.; Li, Y.; Feng, J.; Wang, X.; Hao, B.; Shi, R.; Zhang, G. A functional polymorphism T309G in MDM2 gene promoter, intensified by Helicobacter pylori lipopolysaccharide, is associated with both an increased susceptibility and poor prognosis of gastric carcinoma in Chinese patients. BMC Cancer 2013, 13, 126. [CrossRef] [PubMed]

189. Smith, S.M.; Freeley, M.; Moynagh, P.N.; Kelleher, D.P. Differential modulation ofHelicobacter pylorilipopolysaccharide-mediated TLR2 signaling by individual Pellino proteins. Helicobacter 2016, 22. [CrossRef] [PubMed]

190. Slomiany, B.L.; Slomiany, A. Disruption in gastric mucin synthesis by Helicobacter pylori lipopolysaccharide involves ERK and p38 mitogen-activated protein kinase participation. Biochem. Biophys. Res. Commun. 2002, 294, 220-224. [CrossRef]

191. Young, G.O.; Brown, S.; Stemmet, N.; Lastovica, A.J.; Marks, I.N.; Modlin, I.M.; Kidd, M. The Pepsinogen Releasing Effect of Helicobacter pylori Lipopolysaccharide. Helicobacter 2002, 7, 30-38. [CrossRef]

192. Reeves, E.P.; Ali, T.; Leonard, P.; Hearty, S.; Okennedy, R.; May, F.E.; Westley, B.R.; Josenhans, C.; Rust, M.; Suerbaum, S.; et al. Helicobacter pylori Lipopolysaccharide Interacts With TFF1 in a pH-Dependent Manner. Gastroenterology 2008, 135. [CrossRef]

193. Ye, F.; Tang, C.; Shi, W.; Qian, J.; Xiao, S.; Gu, M.; Zhang, G. A MDM2-dependent positive-feedback loop is involved in inhibition of miR-375 and miR-106b induced byHelicobacter pylorilipopolysaccharide. Int. J. Cancer 2014, 136, 2120-2131. [CrossRef]

194. Hassan, A.A.; Youssef, A.I.; Ghazal, A.A.; Sheta, M.I.; Diwedar, N.L.; Hafez, E.M.; Tabll, A.A.; Elbendary, E.Y. Blood group antigen-Binding Adhesion2 (BabA2) gene in gastric tissue biopsies as a diagnostic biomarker for Helicobacter pylori infection. Hum. Antib. 2019, 27, 193-199. [CrossRef] [PubMed]

195. Torres, L.E.; Melian, K.; Moreno, A.; Alonso, J.; Sabatier, C.A.; Hernandez, M.; Bermudez, L.; Rodriguez, B.L. Prevalence of vacA, cagA and babA2 genes in Cuban Helicobacter pylori isolates. World J. Gastroenterol. 2009, 15, 204. [CrossRef] [PubMed]

196. Thorell, K.; Hosseini, S.; Gonzáles, R.V.P.P.; Chaotham, C.; Graham, D.Y.; Paszat, L.; Rabeneck, L.; Lundin, S.B.; Nookaew, I.; Sjoling, A. Identification of a Latin American-specific BabA adhesin variant through whole genome sequencing of Helicobacter pylori patient isolates from Nicaragua. BMC Evol. Biol. 2016, 16, 53. [CrossRef] [PubMed]

197. Homan, M.; Šterbenc, A.; Kocjan, B.J.; Luzar, B.; Zidar, N.; Orel, R. Prevalence of the Helicobacter pylori babA2 gene and correlation with the degree of gastritis in infected Slovenian children. Antonie van Leeuwenhoek 2014, 106, 637-645. [CrossRef] [PubMed]

198. Rad, R.; Gerhard, M.; Lang, R.; Schöniger, M.; Rösch, T.; Schepp, W.; Becker, I.; Wagner, H.; Prinz, C. TheHelicobacter pyloriBlood Group Antigen-Binding Adhesin Facilitates Bacterial Colonization and Augments a Nonspecific Immune Response. J. Immunol. 2002, 168, 3033-3041. [CrossRef] [PubMed]

199. Yamaoka, Y. Roles of Helicobacter pylori BabA in gastroduodenal pathogenesis. World J. Gastroenterol. 2008, 14, 4265. [CrossRef] [PubMed]

200. Benktander, J.; Ångström, J.; Breimer, M.E.; Teneberg, S. Redefinition of the Carbohydrate Binding Specificity ofHelicobacter pyloriBabA Adhesin. J. Biol. Chem. 2012, 287, 31712-31724. [CrossRef] [PubMed]

201. Ansari, S.; Yamaoka, Y. Helicobacter pylori BabA in adaptation for gastric colonization. World J. Gastroenterol. 2017, $23,4158$. [CrossRef] [PubMed]

202. Morozov, V.; Borkowski, J.; Hanisch, F.-G. The Double Face of Mucin-Type O-Glycans in Lectin-Mediated Infection and Immunity. Molecules 2018, 23, 1151. [CrossRef] [PubMed] 
203. Magalhães, A.; Reis, C. Helicobacter pylori adhesion to gastric epithelial cells is mediated by glycan receptors. Braz. J. Med. Biol. Res. 2010, 43, 611-618. [CrossRef] [PubMed]

204. Lindén, S.; Nordman, H.; Hedenbro, J.; Hurtig, M.; Borén, T.; Carlstedt, I. Strain- and blood group-dependent binding of Helicobacter pylori to human gastric MUC5AC glycoforms. Gastroenterology 2002, 123, 1923-1930. [CrossRef] [PubMed]

205. Ishijima, N.; Suzuki, M.; Ashida, H.; Ichikawa, Y.; Kanegae, Y.; Saito, I.; Mimuro, H. BabA-mediated Adherence Is a Potentiator of theHelicobacter pyloriType IV Secretion System Activity. J. Biol. Chem. 2011, 286, 25256-25264. [CrossRef] [PubMed]

206. Xie, X.; Ito, M.; Sumii, M.; Tanaka, S.; Yoshihara, M.; Chayama, K. Helicobacter pylori-Associated Gastritis Is Related to babA2Expression without Heterogeneity of the $3^{\prime}$ Region of the cagAGenotype in Gastric Biopsy Specimens. Pathobiology 2007, 74, 309-316. [CrossRef] [PubMed]

207. Saberi, S.; Schmidt, A.; Eybpoosh, S.; Esmaili, M.; Talebkhan, Y.; Mohajerani, N.; Oghalaie, A.; Hosseini, M.E.; Mohagheghi, M.A.; Bugaytova, J.; et al. Helicobacter pylori Strains from Duodenal Ulcer Patients Exhibit Mixed babA/B Genotypes with Low Levels of BabA Adhesin and Lewis b Binding. Dig. Dis. Sci. 2016, 61, 2868-2877. [CrossRef]

208. Ohno, T.; Vallström, A.; Rugge, M.; Ota, H.; Graham, D.Y.; Arnqvist, A.; Yamaoka, Y. Effects of Blood Group Antigen-Binding Adhesin Expression during Helicobacter pylori Infection of Mongolian Gerbils. J. Infect. Dis. 2011, 203, 726-735. [CrossRef]

209. Poursina, F.; Faghri, J.; Moghim, S.; Zarkesh-Esfahani, H.; Nasr-Esfahani, B.; Fazeli, H.; Hasanzadeh, A.; Safaei, H.G. Assessment of cagE and babA mRNA Expression During Morphological Conversion of Helicobacter pylori From Spiral to Coccoid. Curr. Microbiol. 2012, 66, 406-413. [CrossRef]

210. Hennig, E.E.; Mernaugh, R.; Edl, J.; Cao, P.; Cover, T.L. Heterogeneity among Helicobacter pylori Strains in Expression of the Outer Membrane Protein BabA. Infect. Immun. 2004, 72, 3429-3435. [CrossRef]

211. Sáenz, J.B.; Vargas, N.; Mills, J.C. Tropism for Spasmolytic Polypeptide-Expressing Metaplasia Allows Helicobacter pylori to Expand Its Intragastric Niche. Gastroenterology 2019, 156, 160-174. [CrossRef]

212. Yanai, A.; Maeda, S.; Hikiba, Y.; Shibata, W.; Ohmae, T.; Hirata, Y.; Ogura, K.; Yoshida, H.; Omata, M. Clinical relevance of Helicobacter pylori sabA genotype in Japanese clinical isolates. J. Gastroenterol. Hepatol. 2007, 22, 2228-2232. [CrossRef]

213. Sheu, B.-S.; Odenbreit, S.; Hung, K.-H.; Liu, C.-P.; Sheu, S.-M.; Yang, H.-B.; Wu, J.-J. Interaction Between Host Gastric Sialyl-Lewis $X$ and H. pylori SabA Enhances, H. pylori Density in Patients Lacking Gastric Lewis B Antigen. Am. J. Gastroenterol. 2006, 101, 36-44. [CrossRef]

214. Yamaoka, Y. Increasing evidence of the role of Helicobacter pylori SabA in the pathogenesis of gastroduodenal disease. J. Infect. Dev. Ctries. 2008, 2, 174. [CrossRef] [PubMed]

215. Unemo, M.; Aspholm-Hurtig, M.; Ilver, D.; Bergström, J.; Borén, T.; Danielsson, D.; Teneberg, S. The Sialic Acid Binding SabA Adhesin ofHelicobacter pyloriIs Essential for Nonopsonic Activation of Human Neutrophils. J. Biol. Chem. 2005, $280,15390-15397$. [CrossRef] [PubMed]

216. Petersson, C.; Forsberg, M.; Aspholm, M.; Olfat, F.O.; Forslund, T.; Borén, T.; Magnusson, K. Helicobacter pylori SabA adhesin evokes a strong inflammatory response in human neutrophils which is down-regulated by the neutrophil-activating protein. Med. Microbiol. Immunol. 2006, 195, 195-206. [CrossRef] [PubMed]

217. Su, Y.-L.; Huang, H.-L.; Huang, B.-S.; Chen, P.-C.; Chen, C.-S.; Wang, H.-L.; Lin, P.; Chieh, M.; Wu, J.; Yang, J.; et al. Combination of OipA, BabA, and SabA as candidate biomarkers for predicting Helicobacter pylori-related gastric cancer. Sci. Rep. 2016, 6. [CrossRef] [PubMed]

218. Kato, S.; Osaki, T.; Kamiya, S.; Zhang, X.S.; Blaser, M.J. Helicobacter pylori sabA gene is associated with iron deficiency anemia in childhood and adolescence. PLoS ONE 2017, 12, e0184046. [CrossRef]

219. Shao, L.; Takeda, H.; Fukui, T.; Mabe, K.; Han, J.; Kawata, S.; Ootani, K.; Fukao, A. Genetic diversity of the Helicobacter pylori sialic acid-binding. Biosci. Trends 2010, 4, 249-253.

220. Zhang, J.; Qian, J.; Zhang, X.; Zou, Q. Outer membrane inflammatory protein A, a new virulence factor involved in the pathogenesis of Helicobacter pylori. Mol. Biol. Rep. 2014, 41, 7807-7814. [CrossRef]

221. Teymournejad, O.; Mobarez, A.M.; Hassan, Z.M.; Abadi, A.T.B. Binding of the Helicobacter pylori OipA causes apoptosis of host cells via modulation of Bax/Bcl-2 levels. Sci. Rep. 2017, 7, e8036. [CrossRef]

222. Sallas, M.L.; Santos, M.P.D.; Orcini, W.A.; David, É.B.; Peruquetti, R.L.; Payão, S.L.M.; Rasmussen, L.T. Status (on/off) of oipA gene: Their associations with gastritis and gastric cancer and geographic origins. Arch. Microbiol. 2018, 201, 93-97. [CrossRef]

223. Teymournejad, O.; Mobarez, A.M.; Hassan, Z.M.; Noori, S.; Moazzeni, S.M.; Khoramabadi, N. Cloning, Expression, Purification and Toxicity Evaluation of Helicobacter pylori Outer Inflammatory Protein, A. Indian J. Microbiol. 2013, 53, 391-394. [CrossRef]

224. Al-Maleki, A.R.; Loke, M.F.; Lui, S.Y.; Ramli, N.S.K.; Khosravi, Y.; Ng, C.G.; Venkatraman, G.; Goh, K.; Ho, B.; Vadivelu, J. Helicobacter pyloriouter inflammatory protein A (OipA) suppresses apoptosis of AGS gastric cells in vitro. Cell. Microbiol. 2017, 19, e12771. [CrossRef] [PubMed]

225. Sugimoto, M.; Ohno, T.; Graham, D.Y.; Yamaoka, Y. Gastric mucosal interleukin-17 and -18 mRNA expression in Helicobacter pylori-induced Mongolian gerbils. Cancer Sci. 2009, 100, 2152-2159. [CrossRef] [PubMed]

226. Sakurai, Y.; Otani, Y.; Kameyama, K.; Hosoda, Y.; Okazaki, I.; Kubota, T.; Kumai, K.; Kitajima, M. Expression of interstitial collagenase (matrix metalloproteinase-1) in gastric cancers. Jpn. J. Cancer Res. 1997, 88, 401-406. [CrossRef] [PubMed]

227. Yamaoka, Y.; Kwon, D.H.; Graham, D.Y. A Mr 34,000 proinflammatory outer membrane protein (oipA) of Helicobacter pylori. Proc. Natl. Acad. Sci. USA 2000, 97, 7533-7538. [CrossRef] [PubMed] 
228. Sugimoto, M.; Ohno, T.; Graham, D.Y.; Yamaoka, Y. Helicobacter pylori outer membrane proteins on gastric mucosal interleukin 6 and 11 expression in Mongolian gerbils. J. Gastroenterol. Hepatol. 2011, 26, 1677-1684. [CrossRef] [PubMed]

229. Mobarez, A.; Moazzeni, S.; Eskandari, V.; Teymournejad, O.; Hassan, Z.; Yakhchali, B. In silico prediction of exposure amino acid sequences of outer inflammatory protein A of Helicobacter pylori for surface display on Eschierchia coli. Indian J. Hum. Genet. 2012, 18, 83. [CrossRef] [PubMed]

230. Zhao, Q.; Yin, W.; Zhao, R.; Wang, Y.; Song, C.; Wang, H.; Rong, J.; Wang, F.; Xie, Y. Outer inflammatory protein of Helicobacter pylori impacts IL-8 expression, adherence, cell apoptosis and cell cycle of gastric cells independent of its copy number. Med. Microbiol. Immunol. 2020, 209, 621-630. [CrossRef]

231. Franco, A.T.; Israel, D.A.; Washington, M.K.; Krishna, U.; Fox, J.G.; Rogers, A.B.; Neish, A.S.; Collier-Hyams, L.; Perez-Perez, G.I.; Hatakeyama, M.; et al. Activation of beta-catenin by carcinogenic Helicobacter pylori. Proc. Natl. Acad. Sci. USA 2005, 102, 10646-10651. [CrossRef]

232. Teymournejad, O.; Mobarez, A.M.; Hassan, Z.M.; Moazzeni, S.M.; Ahmadabad, H.N. In Vitro Suppression of Dendritic Cells byHelicobacter pyloriOipA. Helicobacter 2014, 19, 136-143. [CrossRef]

233. Markovska, R.; Boyanova, L.; Yordanov, D.; Gergova, G.; Mitov, I. Helicobacter pylori oipA genetic diversity and its associations with both disease and cagA, vacA s, m, and i alleles among Bulgarian patients. Diagn. Microbiol. Infect. Dis. 2011, 71, 335-340. [CrossRef]

234. Horridge, D.N.; Begley, A.A.; Kim, J.; Aravindan, N.; Fan, K.; Forsyth, M.H. Outer inflammatory protein a (OipA) of Helicobacter pylori is regulated by host cell contact and mediates CagA translocation and interleukin-8 response only in the presence of a functional cag pathogenicity island type IV secretion system. Pathogens Dis. 2017, 75, ftx113. [CrossRef] [PubMed]

235. Farzi, N.; Yadegar, A.; Aghdaei, H.A.; Yamaoka, Y.; Zali, M.R. Genetic diversity and functional analysis of oipA gene in association with other virulence factors among Helicobacter pylori isolates from Iranian patients with different gastric diseases. Infect. Genet. Evol. 2018, 60, 26-34. [CrossRef] [PubMed]

236. Du, J.; Li, X.-H.; Liu, F.; Li, W.-Q.; Gong, Z.-C.; Li, Y.-J. Role of the Outer Inflammatory Protein A/Cystine-Glutamate Transporter Pathway in Gastric Mucosal Injury Induced by Helicobacter pylori. Clin. Transl. Gastroenterol. 2020, 11, e00178. [CrossRef] [PubMed]

237. Imagawa, S.; Ito, M.; Yoshihara, M.; Eguchi, H.; Tanaka, S.; Chayama, K. Helicobacter pylori dupA and gastric acid secretion are negatively associated with gastric cancer development. J. Med. Microbiol. 2010, 59 Pt 12, 1484-1489. [CrossRef] [PubMed]

238. Zhang, Z.; Zheng, Q.; Chen, X.; Xiao, S.; Liu, W.; Lu, H. The Helicobacter pylori duodenal ulcer promoting gene, DupA in China. BMC Gastroenterol. 2008, 8, 49. [CrossRef]

239. Douraghi, M.; Mohammadi, M.; Oghalaie, A.; Abdirad, A.; Mohagheghi, M.A.; Hosseini, M.E.; Zeraati, H.; Ghasemi, A.; Esmaieli, M.; Mohajerani, N. dupA as a risk determinant in Helicobacter pylori infection. J. Med. Microbiol. 2008, 57, 554-562. [CrossRef]

240. Takahashi, A.; Shiota, S.; Matsunari, O.; Watada, M.; Suzuki, R.; Nakachi, S.; Kinjo, N.; Kinjo, F.; Yamaoka, Y. Intact long-type dupA as a marker for gastroduodenal diseases in Okinawan subpopulation, Japan. Helicobacter 2013, 18, 66-72. [CrossRef]

241. Molina-Castro, S.; Garita-Cambronero, J.; Malespin-Bendana, W.; Une, C.; Remirez, V. Virulence factor genotyping of Helicobacter pylori isolated from Costa Rican dyspeptic patients. Microb. Pathogen. 2019, 128, 276-280. [CrossRef]

242. Wang, M.-Y.; Chen, C.; Shao, C.; Wang, S.-B.; Wang, A.-C.; Yang, Y.-C.; Yuan, X.; Shao, S. Intact long-type DupA protein in Helicobacter pylori is an ATPase involved in multifunctional biological activities. Microb. Pathogen. 2015, 81, 53-59. [CrossRef]

243. Hussein, N.R. The association of dupA and Helicobacter pylori-related gastroduodenal diseases. Eur. J. Clin. Microbiol. Infect. Dis. 2010, 29, 817-821. [CrossRef]

244. Schmidt, H.M.; Andres, S.; Kaakoush, N.O.; Engstrand, L.; Eriksson, L.; Goh, K.L.; Fock, K.M.; Hilmi, I.; Dhamodaran, S.; Forman, D.; et al. The prevalence of the duodenal ulcer promoting gene (dupA) in Helicobacter pylori isolates varies by ethnic group and is not universally associated with disease development: A case-control study. Gut Pathog. 2009, 1, 5. [CrossRef] [PubMed]

245. Wang, M.Y.; Shao, C.; Li, J.; Yang, Y.C.; Wang, S.B.; Hao, J.L.; Wu, C.M.; Gao, X.Z.; Shao, S.H. Helicobacter pylori with the Intact dupA Cluster is more Virulent than the Strains with the Incomplete dupA Cluster. Curr. Microbiol. 2015, 71, 16-23. [CrossRef] [PubMed]

246. Abadi, A.T.B. The Helicobacter pylori dupA: A Novel Biomarker for Digestive Diseases. Front. Med. $2014,1,13$.

247. Shiota, S.; Matsunari, O.; Watada, M.; Hanada, K.; Yamaoka, Y. Systematic review and meta-analysis: The relationship between the Helicobacter pylori dupA gene and clinical outcomes. Gut Pathog. 2010, 2, 13. [CrossRef] [PubMed]

248. Queiroz, D.M.; Rocha, G.A.; Rocha, A.M.; Moura, S.B.; Saraiva, I.E.; Gomes, L.I.; Soares, T.F.; Melo, F.F.; Cabral, M.M.; Oliveira, C.A. dupA polymorphisms and risk of Helicobacter pylori-associated diseases. Int. J. Med. Microbiol. 2011, 301, 225-228. [CrossRef]

249. Jung, S.W.; Sugimoto, M.; Shiota, S.; Graham, D.Y.; Yamaoka, Y. The intact dupA cluster is a more reliable Helicobacter pylori virulence marker than dupA alone. Infect. Immun. 2012, 80, 381-387. [CrossRef]

250. Hussein, N.R.; Argent, R.H.; Marx, C.K.; Patel, S.R.; Robinson, K.; Atherton, J.C. Helicobacter pylori dupA is polymorphic, and its active form induces proinflammatory cytokine secretion by mononuclear cells. J. Infect. Dis. 2010, 202, 261-269. [CrossRef]

251. Abadi, A.T.B.; Taghvaei, T.; Wolfram, L.; Kusters, J.G. Infection with Helicobacter pylori strains lacking dupA is associated with an increased risk of gastric ulcer and gastric cancer development. J. Med. Microbiol. 2012, 61, 23-30. [CrossRef]

252. Shiota, S.; Nguyen, L.T.; Murakami, K.; Kuroda, A.; Mizukami, K.; Okimoto, T.; Kodama, M.; Fujioka, T.; Yamaoka, Y. Association of Helicobacter pylori dupA with the failure of primary eradication. J. Clin. Gastroenterol. 2012, 46, 297-301. [CrossRef] 
253. Hussein, N.R.; Tunjel, I.; Majed, H.S.; Yousif, S.T.; Aswad, S.I.; Assafi, M.S. Duodenal ulcer promoting gene 1 (dupA1) is associated with A2147G clarithromycin-resistance mutation but not interleukin-8 secretion from gastric mucosa in Iraqi patients. New Microb. New Infect. 2015, 6, 5-10. [CrossRef]

254. Moura, S.B.; Costa, R.F.A.; Anacleto, C.; Rocha, G.A.; Rocha, A.M.C.; Queiroz, D.M.M. Single Nucleotide Polymorphisms of Helicobacter pylori dupA that Lead to Premature Stop Codons. Helicobacter 2012, 17, 176-180. [CrossRef] [PubMed]

255. Fatahi, G.; Talebi Bezmin Abadi, A.; Peerayeh, S.N.; Forootan, M. Carrying a 112bp-segment in Helicobacter pylori dupA may associate with increased risk of duodenal ulcer. Infect. Genet. Evol. 2019, 73, 21-25. [CrossRef] [PubMed]

256. Souod, N.; Sarshar, M.; Dabiri, H.; Momtaz, H.; Kargar, M.; Mohammadzadeh, A.; Abdi, S. The study of the oipA and dupA genes in Helicobacter pylori strains and their relationship with different gastroduodenal diseases. Gastroenterol. Hepatol. Bed Bench. 2015, 8, S47-S53. [PubMed]

257. Haddadi, M.H.; Bazargani, A.; Khashei, R.; Fattahi, M.R.; Bagheri Lankarani, K.; Moini, M.; Rokni Hosseini, S.M. Different distribution of Helicobacter pylori EPIYA- cagA motifs and dupA genes in the upper gastrointestinal diseases and correlation with clinical outcomes in iranian patients. Gastroenterol. Hepatol. Bed Bench. 2015, 8, S37-S46. [PubMed]

258. Idowu, A.; Mzukwa, A.; Harrison, U.; Palamides, P.; Haas, R.; Mbao, M.; Mamdoo, R.; Bolon, J.; Jolaiya, T.; Smith, S.; et al. Detection of Helicobacter pylori and its virulence factors genes (cagA, dupA, and vacA) among patients with gastroduodenal diseases in Chris Hani Baragwanath Academic Hospital, South Africa. BMC Gastroenterol. 2019, 19, 73. [CrossRef] [PubMed]

259. Odenbreit, S.; Faller, G.; Haas, R. Role of the alpAB proteins and lipopolysaccharide in adhesion of Helicobacter pylori to human gastric tissue. Int. J. Med. Microbiol. 2002, 292, 247-256. [CrossRef] [PubMed]

260. De Jonge, R.; Durrani, Z.; Rijpkema, S.G.; Kuipers, E.J.; van Vliet, A.H.M.; Kusters, J.G. Role of the Helicobacter pylori outermembrane proteins AlpA and AlpB in colonization of the guinea pig stomach. J. Med. Microbiol. 2004, 53, 375-379. [CrossRef] [PubMed]

261. Odenbreit, S.; Till, M.; Hofreuter, D.; Faller, G.; Haas, R. Genetic and functional characterization of the alpAB gene locus essential for the adhesion of Helicobacter pylori to human gastric tissue. Mol. Microbiol. 1999, 31, 1537-1548. [CrossRef]

262. Lu, H.; Wu, J.Y.; Beswick, E.J.; Ohno, T.; Odenbreit, S.; Haas, R.; Reyes, V.E.; Kita, M.; Graham, D.Y.; Yamaoka, Y. Functional and intracellular signaling differences associated with the Helicobacter pylori AlpAB adhesin from Western and East Asian strains. J. Biol. Chem. 2007, 282, 6242-6254. [CrossRef]

263. Xue, J.; Bai, Y.; Chen, Y.; Wang, J.D.; Zhang, Z.S.; Zhang, Y.L.; Zhou, D.Y. Expression of Helicobacter pylori AlpA protein and its immunogenicity. World J. Gastroenterol. 2005, 11, 2260-2263. [CrossRef]

264. Yonezawa, H.; Osaki, T.; Fukutomi, T.; Hanawa, T.; Kurata, S.; Zaman, C.; Hojo, F.; Kamiya, S. Diversification of the AlpB Outer Membrane Protein of Helicobacter pylori Affects Biofilm Formation and Cellular Adhesion. J. Bacteriol. 2016, 199, e00729-16. [CrossRef] [PubMed]

265. Senkovich, O.A.; Yin, J.; Ekshyyan, V.; Conant, C.; Traylor, J.; Adegboyega, P.; McGee, D.J.; Rhoads, R.E.; Slepenkov, S.; Testerman, T.L. Helicobacter pylori AlpA and AlpB bind host laminin and influence gastric inflammation in gerbils. Infect. Immun. 2011, 79, 3106-3116. [CrossRef] [PubMed]

266. Rossez, Y.; Gosset, P.; Boneca, I.G.; Magalhães, A.; Ecobichon, C.; Reis, C.A.; Cieniewski-Bernard, C.; Joncquel Chevalier Curt, M.; Léonard, R.; Maes, E.; et al. The lacdiNAc-specific adhesin LabA mediates adhesion of Helicobacter pylori to human gastric mucosa. J. Infect. Dis. 2014, 210, 1286-1295. [CrossRef] [PubMed]

267. Mthembu, Y.H.; Jin, C.; Padra, M.; Liu, J.; Edlund, J.O.; Ma, H.; Padra, J.; Oscarson, S.; Borén, T.; Karlsson, N.G.; et al. Recombinant mucin-type proteins carrying LacdiNAc on different O-glycan core chains fail to support H. pylori binding. Mol. Omics 2020, 16, 243-257. [CrossRef] [PubMed]

268. Loh, J.T.; Torres, V.J.; Algood, H.M.; McClain, M.S.; Cover, T.L. Helicobacter pylori HopQ outer membrane protein attenuates bacterial adherence to gastric epithelial cells. FEMS Microbiol. Lett. 2008, 289, 53-58. [CrossRef]

269. Yakoob, J.; Abbas, Z.; Mehmood, M.H.; Tariq, K.; Saleem, S.A.; Awan, S.; Malik, A.; Hamid, S.; Khan, R.; Jafri, W. Helicobacter pylori outer membrane protein Q genotypes and their susceptibility to anti-adhesive phytotherapeutic agents. J. Integr. Med. 2017, 15, 398-406. [CrossRef]

270. Sicinschi, L.A.; Correa, P.; Bravo, L.E.; Peek RMJr Wilson, K.T.; Loh, J.T.; Yepez, M.C.; Gold, B.D.; Thompson, D.T.; Cover, T.L.; Schneider, B.G. Non-invasive genotyping of Helicobacter pylori cagA, vacA, and hopQ from asymptomatic children. Helicobacter 2012, 17, 96-106. [CrossRef]

271. Ohno, T.; Sugimoto, M.; Nagashima, A.; Ogiwara, H.; Vilaichone, R.K.; Mahachai, V.; Graham, D.Y.; Yamaoka, Y. Relationship between Helicobacter pylori hopQ genotype and clinical outcome in Asian and Western populations. J. Gastroenterol. Hepatol. 2009, 24, 462-468. [CrossRef]

272. Dara, M.; Khashei, R.; Dehghani, B. High frequency of hopQ genotypes among Iranian Helicobacter pylori clinical isolates. Infez. Med. 2017, 25, 123-126.

273. Yakoob, J.; Abbas, Z.; Khan, R.; Salim, S.A.; Awan, S.; Abrar, A.; Jafri, W. Helicobacter pylori outer membrane protein Q allele distribution is associated with distinct pathologies in Pakistan. Infect. Genet. Evol. 2016, 37, 57-62. [CrossRef]

274. Hamway, Y.; Taxauer, K.; Moonens, K.; Neumeyer, V.; Fischer, W.; Schmitt, V.; Singer, B.B.; Remaut, H.; Gerhard, M.; Mejías-Luque, R. Cysteine Residues in Helicobacter pylori Adhesin HopQ are Required for CEACAM-HopQ Interaction and Subsequent CagA Translocation. Microorganisms 2020, 8, 465. [CrossRef] [PubMed] 
275. Javaheri, A.; Kruse, T.; Moonens, K.; Mejías-Luque, R.; Debraekeleer, A.; Asche, C.I.; Tegtmeyer, N.; Kalali, B.; Bach, N.C.; Sieber, S.A.; et al. Helicobacter pylori adhesin HopQ engages in a virulence-enhancing interaction with human CEACAMs. Nat. Microbiol. 2016, 2, 16189. [CrossRef] [PubMed]

276. Xia, R.; Zhang, B.; Wang, X.; Jia, Q. Pathogenic interactions between Helicobacter pylori adhesion protein HopQ and human cell surface adhesion molecules CEACAMs in gastric epithelial cells. Iran. J. Basic Med. Sci. 2019, 22, 710-715. [PubMed]

277. Feige, M.H.; Sokolova, O.; Pickenhahn, A.; Maubach, G.; Naumann, M. HopQ impacts the integrin $\alpha 5 \beta 1$-independent NF-кB activation by Helicobacter pylori in CEACAM expressing cells. Int. J. Med. Microbiol. 2018, 308, 527-533. [CrossRef] [PubMed]

278. Moonens, K.; Hamway, Y.; Neddermann, M.; Reschke, M.; Tegtmeyer, N.; Kruse, T.; Kammerer, R.; Mejías-Luque, R.; Singer, B.B.; Backert, S.; et al. Helicobacter pyloriadhesin HopQ disrupts trans dimerization in human CEACAMs. EMBO J. 2018, 37, e98665. [CrossRef]

279. Bonsor, D.A.; Zhao, Q.; Schmidinger, B.; Weiss, E.; Wang, J.; Deredge, D.; Beadenkopf, R.; Dow, B.; Fischer, W.; Beckett, D.; et al. The Helicobacter pylori adhesin protein HopQ exploits the dimer interface of human CEACAMs to facilitate translocation of the oncoprotein, C.a.g.A. EMBO J. 2018, 37, e98664. [CrossRef]

280. Königer, V.; Holsten, L.; Harrison, U.; Busch, B.; Loell, E.; Zhao, Q.; Bonsor, D.A.; Roth, A.; Kengmo-Tchoupa, A.; Smith, S.I.; et al. Helicobacter pylori exploits human CEACAMs via HopQ for adherence and translocation of CagA. Nat. Microbiol. 2017, 2, 16188. [CrossRef]

281. Grzeszczuk, M.J.; Bocian-Ostrzycka, K.M.; Banaś, A.M.; Roszczenko-Jasinska, P.; Malinowska, A.; Stralova, H.; Haas, R.; Meyer, T.F.; Jagusztyn-Krynicka, E.K. Thioloxidoreductase HP0231 of Helicobacter pylori impacts HopQ-dependent CagA translocation. Int. J. Med. Microbiol. 2018, 308, 977-985. [CrossRef]

282. Behrens, I.-K.; Busch, B.; Ishikawa-Ankerhold, H.; Palamides, P.; Shively, J.E.; Stanners, C.; Chan, C.; Leung, N.; Gray-Owen, S.; Haas, R. The HopQ-CEACAM Interaction Controls CagA Translocation, Phosphorylation, and Phagocytosis of Helicobacter pylori in Neutrophils. $m$ Bio 2020, 11. [CrossRef]

283. Gur, C.; Maalouf, N.; Gerhard, M.; Singer, B.B.; Emgård, J.; Temper, V.; Neuman, T.; Mandelboim, O.; Bachrach, G. The Helicobacter pylori HopQ outermembrane protein inhibits immune cell activities. Oncoimmunology 2019, 8, e1553487. [CrossRef]

284. Belogolova, E.; Bauer, B.; Pompaiah, M.; Asakura, H.; Brinkman, V.; Ertl, C.; Bartfeld, S.; Nechitaylo, T.Y.; Haas, R.; Machuy, N.; et al. Helicobacter pylori outer membrane protein HopQ identified as a novel T4SS-associated virulence factor. Cell. Microbiol. 2013, 15, 1896-1912. [PubMed]

285. Peck, B.; Ortkamp, M.; Diehl, K.D.; Hundt, E.; Knapp, B. Conservation, localization and expression of HopZ, a protein involved in adhesion of Helicobacter pylori. Nucleic Acids Res. 1999, 27, 3325-3333. [CrossRef] [PubMed]

286. Kennemann, L.; Brenneke, B.; Andres, S.; Engstrand, L.; Meyer, T.F.; Aebischer, T.; Josenhans, C.; Suerbaum, S. In vivo sequence variation in HopZ, a phase-variable outer membrane protein of Helicobacter pylori. Infect. Immun. 2012, 80, 4364-4373. [CrossRef] [PubMed]

287. van Doorn, L.J.; Figueiredo, C.; Sanna, R.; Plaisier, A.; Schneeberger, P.; de Boer, W.; Quint, W. Clinical relevance of the cagA, vacA, and iceA status of Helicobacter pylori. Gastroenterology 1988, 115, 58-66. [CrossRef]

288. Boyanova, L.; Yordanov, D.; Gergova, G.; Markovska, R.; Mitov, I. Association of iceA and babA genotypes in Helicobacter pylori strains with patient and strain characteristics. Antonie Van Leeuwenhoek 2010, 98, 343-350. [CrossRef] [PubMed]

289. Shiota, S.; Watada, M.; Matsunari, O.; Iwatani, S.; Suzuki, R.; Yamaoka, Y. Helicobacter pylori iceA, clinical outcomes, and correlation with cagA: A meta-analysis. PLoS ONE 2012, 7, e30354. [CrossRef] [PubMed]

290. Yamaoka, Y.; Kodama, T.; Gutierrez, O.; Kim, J.G.; Kashima, K.; Graham, D.Y. Relationship between Helicobacter pylori iceA, cagA, and vacA status and clinical outcome: Studies in four different countries. J. Clin. Microbiol. 1999, 37, 2274-2279. [CrossRef] [PubMed]

291. Wei, G.C.; Chen, J.; Liu, A.Y.; Zhang, M.; Liu, X.J.; Liu, D.; Xu, J.; Liu, B.R.; Ling, H.; Wu, H.X.; et al. Prevalence of Helicobacter pylori vacA, cagA and iceA genotypes and correlation with clinical outcome. Exp. Ther. Med. 2012, 4, 1039-1044. [CrossRef] [PubMed]

292. Ladeira, M.S.; Rodrigues, M.A.; Salvadori, D.M.; Neto, P.P.; Achilles, P.; Lerco, M.M.; Rodrigues, P.A.; Gonçalves IJr Queiroz, D.M.; Freire-Maia, D.V. Relationships between cagA, vacA, and iceA genotypes of Helicobacter pylori and DNA damage in the gastric mucosa. Environ. Mol. Mutagen. 2004, 44, 91-98. [CrossRef]

293. Ladeira, M.S.; Bueno, R.C.; Dos Santos, B.F.; Pinto, C.L.; Prado, R.P.; Silveira, M.G.; Rodrigues, M.A.; Bartchewsky WJr Pedrazzoli JJr Ribeiro, M.L.; Salvadori, D.M. Relationship among oxidative DNA damage, gastric mucosal density and the relevance of cagA, vacA and iceA genotypes of Helicobacter pylori. Dig. Dis. Sci. 2008, 53, 248-255. [CrossRef]

294. Feliciano, O.; Gutierrez, O.; Valdés, L.; Fragoso, T.; Calderin, A.M.; Valdes, A.E.; Llanes, R. Prevalence of Helicobacter pylori vacA, cagA, and iceA Genotypes in Cuban Patients with Upper Gastrointestinal Diseases. BioMed Res. Int. 2015, $2015,753710$. [CrossRef] [PubMed]

295. Ma, Y.J.; Duan, G.C.; Zhang, R.G.; Fan, Q.T.; Zhang, W.D. Mutation of iceA in Helicobacter pylori compromised IL-8 induction from human gastric epithelial cells. J. Basic Microbiol. 2010, 50, S83-S88. [CrossRef] [PubMed]

296. Xu, Q.; Blaser, M.J. Promoters of the CATG-specific methyltransferase gene hpyIM differ between iceA1 and iceA2 Helicobacter pylori strains. J. Bacteriol. 2001, 183, 3875-3884. [CrossRef] [PubMed] 
297. Chiurillo, M.A.; Moran, Y.; Canas, M.; Valderrama, E.; Alvarez, A.; Armanie, E. Combination of Helicobacter pylori-iceA2 and proinflammatory interleukin-1polymorphisms is associated with the severity of histological changes in Venezuelan chronić gastritis patients. FEMS Immunol. Med. Microbiol. 2010, 59, 170-176. [CrossRef] [PubMed]

298. Nishiya, D.; Shimoyama, T.; Fukuda, S.; Yoshimura, T.; Tanaka, M.; Munakata, A. Evaluation of the clinical relevance of the iceA1 gene in patients with Helicobacter pylori infection in Japan. Scand. J. Gastroenterol. 2000, 35, 36-39.

299. Hoshino, H.; Tsuchida, A.; Kametani, K.; Mori, M.; Nishizawa, T.; Suzuki, T.; Nakamura, H.; Lee, H.; Ito, Y.; Kobayashi, M.; et al. Membrane-associated activation of cholesterol $\alpha$-glucosyltransferase, an enzyme responsible for biosynthesis of cholesteryl- $\alpha$-D-glucopyranoside in Helicobacter pylori critical for its survival. J. Histochem. Cytochem. 2011, 59, 98-105. [CrossRef]

300. Morey, P.; Meyer, T.F. The Sweeping Role of Cholesterol Depletion in the Persistence of Helicobacter pylori Infections. Curr. Top. Microbiol. Immunol. 2019, 421, 209-227.

301. Wunder, C.; Churin, Y.; Winau, F.; Warnecke, D.; Vieth, M.; Lindner, B.; Zähringer, U.; Mollenkopf, H.J.; Heinz, E.; Meyer, T.F. Cholesterol glucosylation promotes immune evasion by Helicobacter pylori. Nat. Med. 2006, 12, 1030-1038. [CrossRef]

302. Beigier-Bompadre, M.; Moos, V.; Belogolova, E.; Allers, K.; Schneider, T.; Churin, Y.; Ignatius, R.; Meyer, T.F.; Aebischer, T. Modulation of the CD4+ T-cell response by Helicobacter pylori depends on known virulence factors and bacterial cholesterol and cholesterol $\alpha$-glucoside content. J. Infect. Dis. 2011, 204, 1339-1348. [CrossRef]

303. Morey, P.; Pfannkuch, L.; Pang, E.; Boccellato, F.; Sigal, M.; Imai-Matsushima, A.; Dyer, V.; Koch, M.; Mollenkopf, H.J.; Schlaermann, P.; et al. Helicobacter pylori Depletes Cholesterol in Gastric Glands to Prevent Interferon Gamma Signaling and Escape the Inflammatory Response. Gastroenterology 2018, 154, 1391-1404. [CrossRef]

304. Wang, H.J.; Cheng, W.C.; Cheng, H.H.; Lai, C.H.; Wang, W.C. Helicobacter pylori cholesteryl glucosides interfere with host membrane phase and affect type IV secretion system function during infection in AGS cells. Mol. Microbiol. 2012, 83, 67-84. [CrossRef] [PubMed]

305. Ito, Y.; Vela, J.L.; Matsumura, F.; Hoshino, H.; Tyznik, A.; Lee, H.; Girardi, E.; Zajonc, D.M.; Liddington, R.; Kobayashi, M.; et al. Helicobacter pylori cholesteryl $\alpha$-glucosides contribute to its pathogenicity and immune response by natural killer $\mathrm{T}$ cells. PLoS ONE 2013, 8, e78191. [CrossRef] [PubMed]

306. Kawakubo, M.; Horiuchi, K.; Matsumoto, T.; Nakayama, J.; Akamatsu, T.; Katsuyama, T.; Ota, H.; Sagara, J. Cholesterol- $\alpha-$ glucosyltransferase gene is present in most Helicobacter species including gastric non-Helicobacter pylori helicobacters obtained from Japanese patients. Helicobacter 2018, 23, e12449. [CrossRef] [PubMed]

307. Lee, H.; Kobayashi, M.; Wang, P.; Nakayama, J.; Seeberger, P.H.; Fukuda, M. Expression cloning of cholesterol alphaglucosyltransferase, a unique enzyme that can be inhibited by natural antibiotic gastric mucin O-glycans, from Helicobacter pylori. Biochem. Biophys. Res. Commun. 2006, 349, 1235-1241. [CrossRef] [PubMed]

308. Lai, C.H.; Huang, J.C.; Cheng, H.H.; Wu, M.C.; Huang, M.Z.; Hsu, H.Y.; Chen, Y.A.; Hsu, C.Y.; Pan, Y.J.; Chu, Y.T.; et al. Helicobacter pylori cholesterol glucosylation modulates autophagy for increasing intracellular survival in macrophages. Cell. Microbiol. 2018, 20, e12947. [CrossRef] [PubMed]

309. Du, S.Y.; Wang, H.J.; Cheng, H.H.; Chen, S.D.; Wang, L.H.; Wang, W.C. Cholesterol glucosylation by Helicobacter pylori delays internalization and arrests phagosome maturation in macrophages. J. Microbiol. Immunol. Infect. 2016, 49, 636-645. [CrossRef] [PubMed]

310. Qaria, M.A.; Kumar, N.; Hussain, A.; Qumar, S.; Doddam, S.N.; Sepe, L.P.; Ahmed, N. Roles of Cholesteryl- $\alpha$-Glucoside Transferase and Cholesteryl Glucosides in Maintenance of Helicobacter pylori Morphology, Cell Wall Integrity, and Resistance to Antibiotics. mBio 2018, 9, e01523. [CrossRef] [PubMed]

311. Ling, S.S.; Khoo, L.H.; Hwang, L.A.; Yeoh, K.G.; Ho, B. Instrumental Role of Helicobacter pylori $\gamma$-Glutamyl Transpeptidase in VacA-Dependent Vacuolation in Gastric Epithelial Cells. PLoS ONE 2015, 10, e0131460. [CrossRef]

312. Ricci, V.; Giannouli, M.; Romano, M.; Zarrilli, R. Helicobacter pylori gamma-glutamyl transpeptidase and its pathogenic role. World J. Gastroenterol. 2014, 20, 630-638. [CrossRef]

313. Flahou, B.; Haesebrouck, F.; Chiers, K.; Deun, K.V.; Smet, L.D.; Devreese, B. Gastric epithelial cell death caused by Helicobacter suis and Helicobacter pylori g-glutamyl transpeptidase is mainly glutathione degradation-dependent. Cell. Microbiol. 2011, 13, 1933-1955. [CrossRef]

314. Busiello, I.; Acquaviva, R.; Popolo, A.D.; Blanchard, T.G.; Ricci, V.; Romano, M.; Zarrilli, R. Helicobacter pylori gglutamyltranspeptidase upregulates COX-2 and EGF-related peptide expression in human gastric cells. Cell. Microbiol. 2004, 6, 255-267. [CrossRef] [PubMed]

315. Shibayama, K.; Wachino, J.; Arakawa, Y.; Saidijam, M.; Rutherford, N.G.; Henderson, P.J. Metabolism of glutamine and glutathione via gamma-glutamyltranspeptidase and glutamate transport in Helicobacter pylori: Possible significance in the pathophysiology of the organism. Mol. Microbiol. 2007, 64, 396-406. [CrossRef] [PubMed]

316. Kim, K.M.; Lee, S.G.; Park, M.G.; Song, J.Y.; Kang, H.L.; Leww, W.K.; Cho, M.J.; Rhee, K.; Youn, H.; Baik, S. c-Glutamyltranspeptidase of Helicobacter pylori induces mitochondria-mediated apoptosis in AGS cells. Biochem. Biophys. Res. Commun. 2007, 355, 562-567. [CrossRef] [PubMed]

317. Park, E.H.; Kim, J.M.; Kim, K.M.; Kang, D.; Cho, Y.A.; Choi, J.Y.; Song, J.Y.; Kang, H.L.; Lee, W.K.; Cho, M.J.; et al. Helicobacter pylori $\gamma$-glutamyl transpeptidase-induced $\mathrm{Ca}(2+)$ release via PLC-IP3 receptors in AGS cells. Can. J. Microbiol. 2014, 60, 865-868. [CrossRef] [PubMed] 
318. Schmees, C.; Prinz, C.; Treptau, T.; Rad, R.; Hengst, L.; Voland, P.; Bauer, S.; Brenner, L.; Schmid, R.M.; Gerhard, M. Inhibition of T-cell proliferation by Helicobacter pylori gamma-glutamyl transpeptidase. Gastroenterology 2007, 132, 1820-1833. [CrossRef] [PubMed]

319. Kim, K.M.; Lee, S.G.; Kim, J.M.; Kim, D.S.; Song, J.Y.; Kang, H.L.; Lee, W.K.; Cho, M.J.; Rhee, K.H.; Youn, H.S.; et al. Helicobacter pylori gamma-glutamyltranspeptidase induces cell cycle arrest at the G1-S phase transition. J. Microbiol. 2010, 48, $372-377$. [CrossRef] [PubMed]

320. Boonyanugomol, W.; Chomvarin, C.; Song, J.; Kim, K.; Kim, J.; Cho, M.; Lee, W.; Kang, H.; Rhee, K.; Sripa, B.; et al. Effects of Helicobacter pylori $\gamma$-Glutamyltranspeptidase on Apoptosis and Inflammation in Human Biliary Cells. Dig. Dis. Sci. 2012, 57, 2615-2624. [CrossRef] [PubMed]

321. Oertli, M.; Noben, M.; Engler, D.B.; Semper, R.P.; Reuter, S.; Maxeiner, J.; Gerhard, M.; Taube, C.; Müller, A. Helicobacter pylori $\gamma$-glutamyl transpeptidase and vacuolating cytotoxin promote gastric persistence and immune tolerance. Proc. Natl. Acad. Sci. USA 2013, 110, 3047-3052. [CrossRef]

322. Rossi, M.; Bolz, C.; Revez, J.; Javed, S.; El-Najjar, N.; Anderl, F.; Hyytiäinen, H.; Vuorela, P.; Gerhard, M.; Hänninen, M.L. Evidence for conserved function of $\gamma$-glutamyltranspeptidase in Helicobacter genus. PLoS ONE 2012, 7, e30543. [CrossRef]

323. Wüstner, S.; Anderl, F.; Wanisch, A.; Sachs, C.; Steiger, K.; Nerlich, A.; Vieth, M.; Mejías-Luque, R.; Gerhard, M. Helicobacter pylori $\gamma$-glutamyl transferase contributes to colonization and differential recruitment of T cells during persistence. Sci. Rep. 2017, 7, 13636. [CrossRef]

324. Käbisch, R.; Semper, R.P.; Wüstner, S.; Gerhard, M.; Mejías-Luque, R. Helicobacter pylori $\gamma$-Glutamyltranspeptidase Induces Tolerogenic Human Dendritic Cells by Activation of Glutamate Receptors. J. Immunol. 2016, 196, 4246-4252. [CrossRef] [PubMed]

325. Wüstner, S.; Mejías-Luque, R.; Koch, M.F.; Rath, E.; Vieth, M.; Sieber, S.A.; Haller, D.; Gerhard, M. Helicobacter pylori $\gamma-$ glutamyltranspeptidase impairs T-lymphocyte function by compromising metabolic adaption through inhibition of cMyc and IRF4 expression. Cell. Microbiol. 2015, 17, 51-61.

326. Chevalier, C.; Thiberge, J.M.; Ferrero, R.L.; Labigne, A. Essential role of Helicobacter pylori g-glutamyltranspeptidase for the colonization of the gastric mucosa of mice. Mol. Microbiol. 1999, 31, 1359-1372. [CrossRef] [PubMed]

327. McGovern, K.J.; Blanchard, T.G.; Gutierrez, J.A.; Czinn, S.J.; Krakowka, S.; Youngman, P. gamma-Glutamyltransferase is a Helicobacter pylori virulence factor but is not essential for colonization. Infect. Immun. 2001, 69, 4168-4173. [CrossRef] [PubMed]

328. Gong, M.; Ho, B. Prominent role of gamma-glutamyl-transpeptidase on the growth of Helicobacter pylori. World J. Gastroenterol. 2004, 10, 2994-2996. [CrossRef] [PubMed]

329. Ling, S.S.; Yeoh, K.G.; Ho, B. Helicobacter pylori $\gamma$-glutamyl transpeptidase: A formidable virulence factor. World J. Gastroenterol. 2013, 19, 8203-8210. [CrossRef]

330. Valenzuela, M.; Bravo, D.; Canales, J.; Sanhueza, C.; Díaz, N.; Almarza, O.; Toledo, H.; Quest, A.F. Helicobacter pylori-induced loss of survivin and gastric cell viability is attributable to secreted bacterial gamma-glutamyl transpeptidase activity. J. Infect. Dis. 2013, 208, 1131-1141. [CrossRef] [PubMed]

331. Gong, M.; Ling, S.S.; Lui, S.Y.; Yeoh, K.G.; Ho, B. Helicobacter pylori gamma-glutamyl transpeptidase is a pathogenic factor in the development of peptic ulcer disease. Gastroenterology 2010, 139, 564-573. [CrossRef]

332. Nishioka, H.; Baesso, I.; Semenzato, G.; Trentin, L.; Rappuoli, R.; Del Giudice, G.; Montecucco, C. The neutrophil-activating protein of Helicobacter pylori (HP-NAP) activates the MAPK pathway in human neutrophils. Eur. J. Immunol. 2003, 33, 840-849. [CrossRef]

333. Yokoyama, H.; Fujii, S. Structures and metal-binding properties of Helicobacter pylori neutrophil-activating protein with a di-nuclear ferroxidase center. Biomolecules 2014, 4, 600-615. [CrossRef]

334. Yokoyama, H.; Tsuruta, O.; Akao, N.; Fujii, S. Crystal structure of Helicobacter pylori neutrophil-activating protein with a di-nuclear ferroxidase center in a zinc or cadmium-bound form. Biochem. Biophys. Res. Commun. 2012, 422, 745-750. [CrossRef] [PubMed]

335. Montemurro, P.; Barbuti, G.; Dundon, W.G.; Del Giudice, G.; Rappuoli, R.; Colucci, M.; De Rinaldis, P.; Montecucco, C.; Semeraro, N.; Papini, E. Helicobacter pylori neutrophil-activating protein stimulates tissue factor and plasminogen activator inhibitor-2 production by human blood mononuclear cells. J. Infect. Dis. 2001, 183, 1055-1062. [CrossRef] [PubMed]

336. Polenghi, A.; Bossi, F.; Fischetti, F.; Durigutto, P.; Cabrelle, A.; Tamassia, N.; Cassatella, M.A.; Montecucco, C.; Tedesco, F.; de Bernard, M. The neutrophil-activating protein of Helicobacter pylori crosses endothelia to promote neutrophil adhesion in vivo. J. Immunol. 2007, 178, 1312-1320. [CrossRef] [PubMed]

337. Fu, H.W. Helicobacter pylori neutrophil-activating protein: From molecular pathogenesis to clinical applications. World J. Gastroenterol. 2014, 20, 5294-5301. [CrossRef] [PubMed]

338. Cappon, A.; Babolin, C.; Segat, D.; Cancian, L.; Amedei, A.; Calzetti, F.; Cassatella, M.A.; D’Elios, M.M.; de Bernard, M. Helicobacter pylori-derived neutrophil-activating protein increases the lifespan of monocytes and neutrophils. Cell. Microbiol. 2010, 12, 754-764. [CrossRef] [PubMed]

339. D'Elios, M.M.; Amedei, A.; Cappon, A.; Del Prete, G.; de Bernard, M. The neutrophil-activating protein of Helicobacter pylori (HP-NAP) as an immune modulating agent. FEMS Immunol. Med. Microbiol. 2007, 50, 157-164. [CrossRef]

340. De Bernard, M.; D'Elios, M.M. The immune modulating activity of the Helicobacter pylori HP-NAP: Friend or foe? Toxicon 2010, 56, 1186-1192. [CrossRef] [PubMed]

341. Codolo, G.; Fassan, M.; Munari, F.; Volpe, A.; Bassi, P.; Rugge, M.; Pagano, F.; D’Elios, M.M.; de Bernard, M. HP-NAP inhibits the growth of bladder cancer in mice by activating a cytotoxic Th1 response. Cancer Immunol. Immunother. 2012, 61, 31-40. [CrossRef] 
342. Amedei, A.; Cappon, A.; Codolo, G.; Cabrelle, A.; Polenghi, A.; Benagiano, M.; Tasca, E.; Azzurri, A.; D’Elios, M.M.; Del Prete, G.; et al. The neutrophil-activating protein of Helicobacter pylori promotes Th1 immune responses. J. Clin. Investig. 2006, 116, 1092-1101. [CrossRef]

343. Montemurro, P.; Nishioka, H.; Dundon, W.G.; de Bernard, M.; Del Giudice, G.; Rappuoli, R.; Montecucco, C. The neutrophilactivating protein (HP-NAP) of Helicobacter pylori is a potent stimulant of mast cells. Eur J. Immunol. 2002, 32, 671-676. [CrossRef]

344. Ramachandran, M.; Jin, C.; Yu, D.; Eriksson, F.; Essand, M. Vector-encoded Helicobacter pylori neutrophil-activating protein promotes maturation of dendritic cells with Th1 polarization and improved migration. J. Immunol. 2014, 193, $2287-2296$. [CrossRef] [PubMed]

345. Tonello, F.; Dundon, W.G.; Satin, B.; Molinari, M.; Tognon, G.; Grandi, G.; Del Giudice, G.; Rappuoli, R.; Montecucco, C. The Helicobacter pylori neutrophil-activating protein is an iron-binding protein with dodecameric structure. Mol. Microbiol. 1999, 34, 238-246. [CrossRef] [PubMed]

346. Dundon, W.G.; Polenghi, A.; Guidice, D.; Rappuoli, R.; Montecucco, C. Neutrophil-activating protein (HP-NAP) versus ferritin (Pfr): Comparison of synthesis in Helicobacter pylori. FEMS Microbiol. Lett. 2001, 199, 143-149. [CrossRef] [PubMed]

347. Ceci, P.; Mangiarotti, L.; Rivetti, C.; Chiancone, E. The neutrophil-activating Dps protein of Helicobacter pylori, HP-NAP, adopts a mechanism different from Escherichia coli Dps to bind and condense DNA. Nucleic Acids Res. 2007, 35, 2247-2256. [CrossRef] [PubMed]

348. Hoy, B.; Löwer, M.; Weydig, C.; Carra, G.; Tegtmeyer, N.; Geppert, T.; Schröder, P.; Sewald, N.; Backert, S.; Schneider, G.; et al Helicobacter pylori HtrA is a new secreted virulence factor that cleaves E-cadherin to disrupt intercellular adhesion. EMBO Rep. 2010, 11, 798-804. [CrossRef] [PubMed]

349. Hoy, B.; Geppert, T.; Boehm, M.; Reisen, F.; Plattner, P.; Gadermaier, G.; Sewald, N.; Ferreira, F.; Briza, P.; Schneider, G.; et al. Distinct roles of secreted HtrA proteases from gram-negative pathogens in cleaving the junctional protein and tumor suppressor E-cadherin. J. Biol. Chem. 2012, 287, 10115-10120. [CrossRef]

350. Schmidt, T.P.; Perna, A.M.; Fugmann, T.; Böhm, M.; Jan Hiss Haller, S.; Götz, C.; Tegtmeyer, N.; Hoy, B.; Rau, T.T.; Neri, D.; et al. Identification of E-cadherin signature motifs functioning as cleavage sites for Helicobacter pylori HtrA. Sci. Rep. 2016, 6, 23264. [CrossRef]

351. Zhang, Z.; Huang, Q.; Tao, X.; Song, G.; Zheng, P.; Li, H.; Sun, H.; Xia, W. The unique trimeric assembly of the virulence factor HtrA from Helicobacter pylori occurs via N-terminal domain swapping. J. Biol. Chem. 2019, 294, 7990-8000. [CrossRef]

352. Löwer, M.; Geppert, T.; Schneider, P.; Hoy, B.; Wessler, S.; Schneider, G. Inhibitors of Helicobacter pylori protease HtrA found by 'virtual ligand' screening combat bacterial invasion of epithelia. PLoS ONE 2011, 6, e17986. [CrossRef]

353. Waskito, L.A.; Salama, N.R.; Yamaoka, Y. Pathogenesis of Helicobacter pylori infection. Helicobacter 2018, 23, e12516. [CrossRef]

354. Harrer, A.; Boehm, M.; Backert, S.; Tegtmeyer, N. Overexpression of serine protease HtrA enhances disruption of adherens junctions, paracellular transmigration and type IV secretion of CagA by Helicobacter pylori. Gut Pathog. 2017, 9, 40. [CrossRef] [PubMed]

355. Zawilak-Pawlik, A.; Zarzecka, U.; Żyła-Uklejewicz, D.; Lach, J.; Strapagiel, D.; Tegtmeyer, N.; Bohm, M.; Backert, S.; SkorkoGlonek, J. Establishment of serine protease htrA mutants in Helicobacter pylori is associated with secA mutations. Sci. Rep. 2019, 9, 11794. [CrossRef] [PubMed]

356. Tegtmeyer, N.; Moodley, Y.; Yamaoka, Y.; Pernitzsch, S.R.; Schmidt, V.; Traverso, F.R.; Schmidt, T.P.; Rad, R.; Yeoh, K.G.; Bow, H.; et al. Characterisation of worldwide Helicobacter pylori strains reveals genetic conservation and essentiality of serine protease HtrA. Mol. Microbiol. 2016, 99, 925-944. [CrossRef] [PubMed]

357. Bernegger, S.; Brunner, C.; Vizovišek, M.; Fonovic, M.; Cuciniello, G.; Giordano, F.; Stanojlovic, V.; Jarzab, M.; Simister, P.; Feller, S.M.; et al. A novel FRET peptide assay reveals efficient Helicobacter pylori HtrA inhibition through zinc and copper binding. Sci. Rep. 2020, 10, 10563. [CrossRef] [PubMed]

358. Schmidt, T.P.; Goetz, C.; Huemer, M.; Schneider, G.; Wessler, S. Calcium binding protects E-cadherin from cleavage by Helicobacter pylori HtrA. Gut Pathog. 2016, 8, 29. [CrossRef]

359. Zarzecka, U.; Modrak-Wójcik, A.; Figaj, D.; Apanowicz, M.; Lesner, A.; Bzowska, A.; Lipinska, B.; Zawilak-Pawlik, A.; Backert, S.; Skorko-Glonek, J. Properties of the HtrA Protease from Bacterium Helicobacter pylori Whose Activity Is Indispensable for Growth Under Stress Conditions. Front. Microbiol. 2019, 10, 961. [CrossRef]

360. Zarzecka, U.; Harrer, A.; Zawilak-Pawlik, A.; Skorko-Glonek, J.; Backert, S. Chaperone activity of serine protease HtrA of Helicobacter pylori as a crucial survival factor under stress conditions. Cell Commun. Signal. 2019, 17, 161. [CrossRef]

361. Buommino, E.; Donnarumma, G.; Manente, L.; De Filippis, A.; Silvestri, F.; Iaquinto, S.; Tufano, M.A.; De Luca, A. The Helicobacter pylori protein HspB interferes with Nrf2/Keap1 pathway altering the antioxidant response of Ags cells. Helicobacter 2012, 17, 417-425. [CrossRef]

362. Du, R.J.; Ho, B.T.D. Surface localized Heat Shock Protein 20 (HslV) of Helicobacter pylori. Helicobacter 2003, 8, 257-267. [CrossRef]

363. Cun, S.; Li, H.; Ge, R.; Lin, M.C.; Sun, H. A histidine-rich and cysteine-rich metal-binding domain at the $C$ terminus of heat shock protein A from Helicobacter pylori: Implication for nickel homeostasis and bismuth susceptibility. J. Biol. Chem. 2008, 283, 15142-15151. [CrossRef]

364. Takenaka, R.; Yokota, K.; Ayada, K.; Mizuno, M.; Zhao, Y.; Fujinami, Y.; Lin, S.N.; Toyokawa, T.; Okada, H.; Shiratori, Y.; et al Helicobacter pylori heat-shock protein 60 induces inflammatory responses through the Toll-like receptor-triggered pathway in cultured human gastric epithelial cells. Microbiology 2004, 150, 3913-3922. [CrossRef] [PubMed] 
365. Lin, S.N.; Ayada, K.; Zhao, Y.; Yokota, K.; Takenaka, R.; Okada, H.; Kan, R.; Hayashi, S.; Mizuno, M.; Hirai, Y.; et al. Helicobacter pylori heat-shock protein 60 induces production of the pro-inflammatory cytokine IL8 in monocytic cells. J. Med. Microbiol. 2005, 54, 225-233. [CrossRef] [PubMed]

366. Zhao, Y.; Yokota, K.; Ayada, K.; Yamamoto, Y.; Okada, T.; Shen, L.; Oguma, K. Helicobacter pylori heat-shock protein 60 induces interleukin-8 via a Toll-like receptor (TLR)2 and mitogen-activated protein (MAP) kinase pathway in human monocytes. J. Med. Microbiol. 2007, 56, 154-164. [CrossRef] [PubMed]

367. Liao, K.W.; Lin, C.S.; Chen, W.L.; Yang, C.T.; Lin, C.M.; Hsu, W.T.; Lin, Y.Y.; Chiu, Y.H.; Huang, K.C.; Wu, H.Y.; et al. Antibodies against Helicobacter pylori heat shock protein 60 aggravate HSP60-mediated proinflammatory responses. Cytokine 2011, 55, 174-180. [CrossRef] [PubMed]

368. Gobert, A.P.; Bambou, J.C.; Werts, C.; Balloy, V.; Chignard, M.; Moran, A.P.; Ferrero, R.L. Helicobacter pylori heat shock protein 60 mediates interleukin-6 production by macrophages via a toll-like receptor (TLR)-2-, TLR-4-, and myeloid differentiation factor 88-independent mechanism. J. Biol. Chem. 2004, 279, 245-250. [CrossRef] [PubMed]

369. Hsu, W.T.; Ho, S.Y.; Jian, T.Y.; Huang, H.N.; Lin, Y.L.; Chen, C.H.; Lin, T.H.; Wu, M.S.; Wu, C.J.; Chan, Y.L.; et al. Helicobacter pylori-derived heat shock protein 60 increases the induction of regulatory T-cells associated with persistent infection. Microb. Pathog. 2018, 119, 152-161. [CrossRef]

370. Schauer, K.; Muller, C.; Carrière, M.; Labigne, A.; Cavazza, C.; De Reuse, H. The Helicobacter pylori GroES cochaperonin HspA functions as a specialized nickel chaperone and sequestration protein through its unique C-terminal extension. J. Bacteriol. 2010, 192, 1231-1237. [CrossRef]

371. Roncarati, D.; Danielli, A.; Spohn, G.; Delany, I.; Scarlato, V. Transcriptional regulation of stress response and motility functions in Helicobacter pylori is mediated by HspR and HrcA. J. Bacteriol. 2007, 189, 7234-7243. [CrossRef]

372. Eamranond, P.P.; Torres, J.; Muñoz, O.; Pérez-Pérez, G.I. Age-specific immune response to HspA in Helicobacter pylori-positive persons in Mexico. Clin. Diagn. Lab. Immunol. 2004, 11, 983-985. [CrossRef]

373. Lin, C.S.; He, P.J.; Hsu, W.T.; Wu, M.S.; Wu, C.J.; Shen, H.W.; Hwang, C.H.; Lai, Y.K.; Tsai, N.M.; Liao, K.W. Helicobacter pylori-derived Heat shock protein 60 enhances angiogenesis via a CXCR2-mediated signaling pathway. Biochem. Biophys. Res. Commun. 2010, 397, 283-289. [CrossRef]

374. Takenaka, R.; Yokota, K.; Mizuno, M.; Okada, H.; Toyokawa, T.; Yamasaki, R.; Yoshino, T.; Sugiyama, T.; Asaka, M.; Shiratori, Y.; et al. Serum antibodies to Helicobacter pylori and its heat-shock protein 60 correlate with the response of gastric mucosa-associated lymphoid tissue lymphoma to eradication of H. pylori. Helicobacter 2004, 9, 194-200. [CrossRef] [PubMed]

375. Ishii, E.; Yokota, K.; Sugiyama, T.; Fujinaga, Y.; Ayada, K.; Hokari, I.; Hayashi, S.; Hirai, Y.; Asaka, M.; Oguma, K. Immunoglobulin G1 antibody response to Helicobacter pylori heat shock protein 60 is closely associated with low-grade gastric mucosa-associated lymphoid tissue lymphoma. Clin. Diagn. Lab. Immunol. 2001, 8, 1056-1059. [CrossRef] [PubMed]

376. Yunoki, N.; Yokota, K.; Mizuno, M.; Kawahara, Y.; Adachi, M.; Okada, H.; Hayashi, S.; Hirai, Y.; Oguma, K.; Tsuji, T. Antibody to heat shock protein can be used for early serological monitoring of Helicobacter pylori eradication treatment. Clin. Diagn. Lab. Immunol. 2000, 7, 574-577. [CrossRef] [PubMed]

377. Liu, W.; Chen, Y.; Lu, G.; Sun, L.; Si, J. Down-regulation of HSP70 sensitizes gastric epithelial cells to apoptosis and growth retardation triggered by H. pylori. BMC Gastroenterol. 2011, 11, 146. [CrossRef] [PubMed]

378. Targosz, A.; Brzozowski, T.; Pierzchalski, P.; Szczyrk, U.; Ptak-Belowska, A.; Konturek, S.J.; Pawlik, W. Helicobacter pylori promotes apoptosis, activates cyclooxygenase (COX)-2 and inhibits heat shock protein HSP70 in gastric cancer epithelial cells. Inflamm. Res. 2012, 61, 955-966. [CrossRef]

379. Ko, S.H.; Yoo, D.Y.; Kim, Y.J.; Choi, S.M.; Kang, K.K.; Kim, H.; Kim, N.; Kim, J.S.; Kim, J.M. A mechanism for the action of the compound DA-6034 on NF-kB pathway activation in Helicobacter pylori-infected gastric epithelial cells. Scand. J. Immunol. 2011, 74, 253-263. [CrossRef]

380. Barton, S.G.; Rampton, D.S.; Winrow, V.R.; Domizio, P.; Feakins, R.M. Expression of heat shock protein 32 (hemoxygenase-1) in the normal and inflamed human stomach and colon: An immunohistochemical study. Cell Stress Chaperones. 2003, 8, 329-334. [CrossRef]

381. Huang, Q.; Ye, J.; Huang, Q.; Chen, W.; Wang, L.; Lin, W.; Lin, J.; Lin, X. Heat shock protein 27 is over-expressed in tumor tissues and increased in sera of patients with gastric adenocarcinoma. Clin. Chem. Lab. Med. 2010, 48, 263-269. [CrossRef] 